\title{
Railway sparks: technological development and the common law
}

Article

Accepted Version

Wilde, M. (2019) Railway sparks: technological development and the common law. American Journal of Legal History, 59 (4). pp. 444-512. ISSN 0002-9319 doi:

https://doi.org/10.1093/ajlh/njz024 Available at https://centaur.reading.ac.uk/86390/

It is advisable to refer to the publisher's version if you intend to cite from the work. See Guidance on citing.

To link to this article DOI: http://dx.doi.org/10.1093/ajlh/njz024

Publisher: Oxford University Press

All outputs in CentAUR are protected by Intellectual Property Rights law, including copyright law. Copyright and IPR is retained by the creators or other copyright holders. Terms and conditions for use of this material are defined in the End User Agreement.

\section{www.reading.ac.uk/centaur}

\section{CentAUR}

Central Archive at the University of Reading

Reading's research outputs online 


\title{
Railway Sparks: Technological Development and the Common Law
}

\author{
Mark L Wilde*
}

\begin{abstract}
The railways have been described as Britain's 'gift to the world'. The sheer scale, ambition and audaciousness of the engineering still inspires awe and reshaped the landscape forever. They brought towns and cities closer together and instigated irreversible economic, political and social changes. However, as is often the case with a new technology, the railways also brought negative side effects, one of the most destructive of which was fire damage caused by sparks and lighted coals from steam locomotives. The railway sparks issue has long served as a case study for the economic analysis of tort and the issue of where the loss should fall. Nevertheless, much of the analysis has lacked an appreciation of how the courts actually resolved these disputes. This has attracted some comment from tort scholars and legal historians but has never been the subject of a sustained piece of doctrinal or historical research. This article constitutes the first truly comprehensive and in-depth analysis of the cases (both reported and unreported). The study has yielded new insights into the main arguments (and in particular the need to fit spark arresters to locomotives), the attitude of the railway industry to the problem and the role played by such cases in key doctrinal developments such as strict liability. Moreover, it examines how railway interests in Parliament were able to stymy attempts to replace the common law with a much more onerous strict liability regime under statute. As such it affords important new insights into how law responded to some of the new challenges of the Industrial Age.
\end{abstract}

\section{INTRODUCTION}

The exponential growth of the railways in the nineteenth century created many benefits but it also brought about new problems. These included industrial accidents in construction, rail disasters involving casualties on a hitherto unknown scale and nuisance type problems ranging from spooked horses on the highway to noise and vibration. This article focuses on an especially prevalent and destructive side-effect of the railway boom, namely, the problem of railway sparks. In fact, this problem endured for the duration of steam traction on British railways and was still unresolved by the time the last British Rail steam operated mainline service departed Liverpool Lime Street on 11 August 1968. The railways created an entirely new type of land use conflict. Hitherto industrial activities had been static and had only affected landholders in the immediate vicinity of an industrial plant. A steam locomotive, on the other hand, was a mobile furnace progressing through miles of town and countryside showering sparks and red-hot embers in its wake. Thus, farmers and property owners in the shires found that they were no longer beyond the reach of the effects of industrialisation. Clearly, fire damage of this nature was just as destructive as the poisoning or scorching of crops by acidic atmospheric emissions suffered by those living and working closer to the main industrial seats. The common law of tort was called upon to provide remedies for those whose property had been consumed by fires spread by locomotives. Over the course of the nineteenth century and on into the twentieth century, a body of case law emerged on this specific issue.

The term 'railway sparks' has a particular resonance in tort scholarship due to its appearance in the economic analysis of tort. The problem has been used as a case study for examining the economic consequences of various approaches to resolving such disputes through the application of tort-based

\footnotetext{
* Associate Professor in Law, University of Reading. Profound thanks are due to Charlotte Smith, Catharine MacMillan and Mark Lunney for their immensely helpful comments and infinite patience. Any errors or omissions remain the author's own.
} 
principles. ${ }^{1}$ For example, would the imposition of strict liability for fire damage caused by steam locomotives lead to inefficiency by encouraging farmers to cultivate crops in close proximity to railways? If the railway company was bound to pay, irrespective of any fault on its part, one could argue that it would make little difference to the farmer whether he sold his crops at market or received compensation following their destruction - a wasteful and inefficient outcome. On the other hand, would a standard of strict liability incentivise the railway company to reduce its liabilities by developing cost-effective technology capable of mitigating the spark problem? Other scholars are highly critical of the entire economic approach and object to the notion that the effectiveness of law should be judged by reference to narrow economic criteria such as wealth maximisation. Other factors are at work such as the need to secure justice ${ }^{2}$ and the protection of autonomy and freedom through the assertion of property rights. ${ }^{3}$

This article takes an historical rather than an economic analysis approach to the development of the law concerned with railway sparks. It is based on a new examination of the case law which is far more in depth and comprehensive than anything which has gone before. It goes far beyond the key reported authorities and examines a much broader range of lesser-known cases, many of which did not make the law reports. In addition, the litigation is placed in its historical context with reference to archival materials and commentary in contemporary rail industry journals and the mainstream press. In this respect it shines a new light on how the courts actually resolved the railway sparks cases and the principles which were applied. In particular, the little-known role played by the railway sparks cases in the development of strict liability, pre Rylands $v$ Fletcher, is considered: although the cases were also instrumental in developing the concept of statutory authority which shielded the railway companies from liability in the vast majority of cases. Moreover, the extent to which, if at all, the litigation influenced the railway companies in terms of developing technology capable of reducing the railway sparks problem is investigated. On a broader level the railway sparks issue provides a useful case study for examining how the common law reacts to rapid technological change. While the economic analysis cannot be ignored, as it highlights points of historical detail and legal doctrine which provide a useful starting point for an in-depth exploration of this article's themes, it is argued that the economic analysis is based upon certain assumptions of how the law actually worked which need to be challenged.

\section{RAILWAY SPARKS, ECONOMICS AND LEGAL HISTORY}

The railway sparks issue was briefly alluded to by the economist Arthur Cecil Pigou in The Economics of Welfare. ${ }^{4}$ Pigou's concern was that, when left to their own devices, the parties to a transaction often fail to consider the impact of their actions on third parties or bystanders. These costs 'are thrown upon people not directly concerned through, say, uncompensated damage done to surrounding woods by sparks from railway engines'. ${ }^{5}$ In economic parlance such costs are referred to as externalities in that they did not form part of the transaction between the original parties who instigated a scheme, such as a railway promoter and an investor.

Pigou was not explicit on the issue of how these costs should be met, but one obvious solution would have been to throw the costs back onto the railway companies. Indeed, Pigou's usual prescription for such 'market failures' was some form of direct government intervention designed to

\footnotetext{
${ }^{1}$ See AC Pigou, The Economics of Welfare (4th edn, Macmillan 1932) [II.II.5]; RH Coase, 'The Problem of Social Cost' (1960) 3 JL \& Econ 1, 28-34; AW Brian Simpson, Leading Cases in the Common Law (Clarendon Press 1995) 168-69. Those with an interest in the intersections between law and economics continue to return to the theme and recent examples include Eric R Claeys, 'Sparks Cases in Contemporary Law and Economic Scholarship' in Todd J Zywicki and Peter J Boettke (eds), Research Handbook on Austrian Law and Economics (Edward Elgar 2017).

${ }^{2}$ See CAE Goodhart, 'Economics and the Law: Too Much One-way Traffic?' (1997) 60 MLR 1.

${ }^{3}$ See Claeys (n 1).

${ }^{4}$ Pigou (n 1).

5 ibid.
} 
force the parties to recognise these costs. ${ }^{6}$ To use economic terminology once more, if one or both of the parties to the original transaction is made to pay in this way, the externalities are successfully internalised. Although Pigou did not propose any specific solution on this issue, he stated that in deciding what remedy to adopt it was necessary to 'reckon ... up the net social product of the marginal increment of any volume of resources turned into any use or place'. ${ }^{7}$ This means that, from an economic perspective, it is necessary to look beyond the immediate interests of the parties, such as the farmer whose crops were destroyed and the railway company who destroyed them, and consider what solution produces the best outcome for society as a whole. To oversimplify the argument, should the consumer have to pay more for his food because of the amount of produce which has been lost to fire damage? Or should the railway passenger have to pay more for his ticket because of the amount that the railway company has had to pay out in compensation and the cost of abatement measures?

Some years later Ronald Coase expanded upon Pigou's railway sparks example in his celebrated article on 'The Problem of Social Cost'. ${ }^{8}$ Here he sought to explain how the problem was actually dealt with under English law and compared this with how one might approach the issue from an economic perspective. As regards the latter point he noted that the 'social net product' approach might lead to counterintuitive solutions, which would allow the costs to remain where they fell with the injured party. For example, if a farmer knows that he will receive the full market price for his crops, whether or not they are destroyed by fire, he will have no incentive to take avoiding action. For example, he might continue to grow crops which are easily ignited in close proximity to the railway. A system which regularly allowed money to be paid for crops which never made it to market would not be regarded as an efficient solution. ${ }^{9}$ An economist might argue that it would be better for the farmer to avoid cultivating a strip of land immediately adjacent to the railway, to use it for purposes which are less susceptible to fire damage or to sell it outright to the railway company on condition that they maintain it as a fire break. Of course, the outcome would be different if a cost effective solution was available to the railway company which might allow the farmer to cultivate his land in the immediate vicinity of the railway. Coase considered various 'let's suppose' hypothetical scenarios in which the railway company ran fewer trains in order to reduce the frequency of fires. Not surprisingly, this raised the possibility that the reduction in rail services could bring about a reduction in 'net social product'. ${ }^{10}$ Although he mentioned spark arrestors in passing (devices fitted to locomotives which caught the sparks before they escaped into the open air), ${ }^{11}$ he did not consider what effect they might have had on the outcome of these scenarios. In fact, as shall be discussed in detail below, spark arrestors and the issue of whether or not they should be fitted was at the heart of much of the case law.

As regards the actual position under English law, Coase noted that, with limited exceptions, the railway companies enjoyed a statutory authority to cause fire damage without the need to pay compensation. ${ }^{12}$ The limited exception concerned damage falling within the unambitious Railway Fires Acts of 1905 and 1923, which allowed for capped damages in respect of crop damage. Damage which exceeded the low cap on liability and damage to buildings and other property falling outwith the scope of these two acts remained subject to the common law. Thus, by equipping the railway companies with statutory powers to build and operate lines, 'government action' had brought about a situation whereby such losses remained largely uncompensated. He used this finding as grounds for

\footnotetext{
${ }^{6}$ Hence the existence of 'Pigouvian taxes', which have become synonymous with 'green taxes' levied on polluters: see Thomas A Barthold, 'Environmental Taxes, Federal', The Encyclopaedia of Taxation and Tax Policy (2nd edn, 2005) 113.

${ }^{7}$ Pigou (n 1).

${ }^{8}$ Coase (n 1).

9 ibid 32-33.

10 ibid 33-34.

11 ibid 31 .

${ }^{12}$ Coase relied almost entirely for his legal analysis upon the relevant entry in what was then the current edition of Halsbury's Laws (3rd edn, 1960) vol 30, paras 690-91. See Coase (n 1) 24.
} 
challenging Pigou's argument that government intervention normally serves to impose costs on the creator of the harm. ${ }^{13}$

Simpson challenged this assertion more than three decades later on the grounds that there was no evidence to show that there had been a conscious decision on the part of government to relieve the railway companies of liability for fire damage. ${ }^{14}$ The statutory authority defence, to which Coase alluded, was the creation of the courts and was probably far more generous than Parliament would have anticipated. This drew a somewhat testy response from Coase, despite the length of time that had elapsed between the publication of 'The Problem of Social Cost' and Simpson's piece. In short, Coase argued that, by focusing on historical detail, Simpson had missed the main point of the article. ${ }^{15}$ Moreover, his comments on the economic arguments were ill informed and that, as a lawyer, he should not trespass upon economists' territory. Simpson, who must have been shown a proof of Coase's article, was afforded the opportunity to respond in a short addendum published in the same issue of the journal. His response was equally forthright, and he noted that, given that Coase had examined the legal position in some detail, it was a bit rich for him to criticise a lawyer for questioning the economic arguments:

The next thing will be the claim that only God can write about God, saints can write about saints, idiots about idiots, or horses about horses. To be sure there will be differences in approach between writings from within and from outside particular intellectual clubs. ${ }^{16}$

Simpson was correct in his assertion that the railway sparks issue raises important points of history and doctrine, the significance of which may not have been fully appreciated by a scholar from another discipline, however eminent. Given that Coase placed the law at the centre of the debate it was disingenuous of him to downplay the importance of this aspect of his argument, and Simpson was fully entitled to take him to task on his legal analysis. As regards the substantive points made by Simpson, he was entirely correct in pointing out that it was the courts, rather than Parliament, who sculpted the statutory authority defence. In doing so they may have gone much further in terms of limiting the liability of the railway companies than Parliament would have anticipated. This greatly undermined the concept of strict liability, which the courts appeared to have settled upon by the close of the 1860s. Indeed, as will be seen below, strict liability seemed to emerge and then immediately disappear behind statutory authority which shielded the railway companies from liability for railway sparks damage in the vast majority of cases.

However, the manner in which the case law developed was rather more complex than Simpson suggested. It is important to note that a negligence-based standard of liability would not necessarily have absolved the railway companies of liability; in other words, immunity in respect of railway spark damage was not the inevitable consequence of imposing a fault-based standard of care as opposed to strict liability. This was entirely dependent upon what measures were deemed necessary in order to discharge the duty of care. As the following analysis demonstrates, the courts initially imposed an onerous duty on the railway companies, and the only way to discharge the duty was to fit spark arresting devices. In the 1860s this demanding standard of care appeared to stiffen into a rule of strict liability, although this coincided with the crystallisation of the statutory authority defence in the context of railway sparks. However, although the defence prevented strict liability from operating in most railway sparks cases, it did not preclude the victims of railway sparks from continuing to bring actions in negligence. Had the courts continued to adhere to a rigorous interpretation of the duty of care, the emergence of statutory authority would have had little effect (for reasons which are elucidated below, negligence was never covered by statutory authority). Nevertheless, the duty was continually watered down and, for reasons which shall become apparent in due course, the railway

\footnotetext{
${ }^{13}$ Coase (n 1) 30-31.

${ }^{14}$ Simpson (n 1).

${ }^{15}$ RH Coase, 'Law and Economics and AW Brian Simpson' (1996) 25 J Legal Stud 103, 111-13.

${ }^{16}$ AW Brian Simpson, 'An Addendum [A Response to Law and Economics and AW Brian Simpson by RH Coase]' (1996) 25 J Legal Stud 99.
} 
companies relentlessly chipped away at the notion that the fitting of a spark arrestor was the only way to discharge the duty of care.

As regards the role of government in this matter, Coase, in his repost to Simpson, ${ }^{17}$ argued that it was significant that Parliament had only chosen to implement a very limited liability regime in 1905 , which did not cover a significant proportion of the fire damage caused by steam locomotives. Parliament could have expanded the regime and further limited the rule of statutory authority, but it chose not to (save for some very minor amendments in 1923). From this, he contended, it is possible to conclude that a conscious decision was taken to absolve the railway companies of a large part of their potential liabilities resulting from railway sparks. Simpson's response was to the effect that a lack of parliamentary intervention cannot be regarded as tacit approval of the status quo:

It does not follow from this [the lack of legislative intervention] that the rule [statutory authority] depended upon a sort of ongoing negative legislative decision, as if Parliament was continually muttering under its breath, 'Let's be kind to the railways'. ${ }^{18}$

In fact, as will be seen below, a detailed scrutiny of the parliamentary debates reveals that railway interests were strongly represented in the parliamentary proceedings, and there was a keen awareness of the fact that the existing common law position was beneficial to the railway companies. Accordingly, the decision to limit the scope of the liability regime may have been more deliberate than Simpson believed.

Thus, the railway sparks debate in the context of the economics of law raises a number of important historical and doctrinal questions which are subject to a detailed analysis in this article. These shed light on the development of fundamental doctrinal issues such as strict liability and, on a broader level, the manner in which the common law reacts to major technological changes. However, before proceeding to the main discussion, it is necessary to set the railways sparks issue in context by outlining the origins of the problem and early attempts to tackle it.

\section{THE EMERGENCE OF THE RAILWAY SPARKS PROBLEM}

The propensity of steam locomotives to leave a trail of destruction in their wake through the emission of sparks and red-hot coals was evident from the outset of the railway age. In 1832 one Marshall Fowler wrote to the directors of the Stockton and Darlington Railway (the very first railway in the modern sense of the term, which had only opened seven years previously) on two occasions complaining about fire damage to his plantation. ${ }^{19}$ It is not clear what action was taken, if any.

It soon became clear that fire damage was an inherent risk of the technology. Moreover, due to the rapid spread of the technology throughout the land, the problem quickly assumed national significance and attracted the attention of Parliament. In 1836 a House of Lords Select Committee was appointed to investigate the issue ${ }^{20}$ The Committee was prompted in part by a proposal to build a short extension railway from Euston into central London - the London Grand Junction Railway. This is dealt with in more detail below; suffice it to say, it would have passed through heavily built-up areas and prime real estate, the owners of which were greatly concerned about the fire risk. The committee took evidence from many of the leading experts of the day including George and Robert Stephenson, Isambard Kingdom Brunel and George Rennie. Although the specific remit of the inquiry focused on railroads passing through built-up areas, it noted the risk posed to herbage, crops, buildings and other agricultural property in the countryside.

\footnotetext{
${ }^{17}$ Coase (n 15) 112.

${ }^{18}$ Simpson (n 16) 100.

${ }^{19}$ The National Archives (TNA) RAIL 667/1038 Fowler to Directors of the Stockton and Darlington Railway, 25 February 1832; 3 March 1832.

${ }^{20}$ Report from the Select Committee of the House of Lords appointed to inquire whether any Danger by Fire is likely to arise from Locomotives Engines being used on Railroads passing through narrow Streets, with minutes of Evidence and Appendices (HL 1836, 168 - XII).
} 
George Stephenson referred to the hot and dry summer of the previous year and noted that they had had to station men at various points along the Leicester and Swannington Railway for fear that cornfields would be set alight. ${ }^{21}$ Nevertheless, a farm house and several buildings caught fire as a result of sparks from a passing locomotive, together with fencing and grass. Moreover, Stephenson noted, somewhat ruefully that, as a director and shareholder of the company, he had had to pay for part of the damages.

Brunel $^{22}$ also acknowledged the extent of the problem, although at that point in time he had had little direct experience of railway fires. His first railway projects - which went on to form the backbone of the Great Western Railway and with which Brunel is synonymous - were still under construction. Nevertheless, he told the committee that he had travelled extensively and talked to many engineers about the problem. Having visited the Liverpool and Manchester Railway, he was able to confirm vivid eyewitness reports that 'the line of the railway looks red in the dark, from the cinders that have fallen' ${ }^{23} \mathrm{He}$ continued, 'I know the engines often do set fire to hay and corn stacks, but they [the railway company] find it worthwhile to pay the persons and keep it quiet rather than have it published, otherwise you would hear of many more accidents than you do'. ${ }^{24}$

This indicates that the railway companies had largely adopted a policy of paying up on a case by case basis and attempting to draw a veil over the issue. As regards attempts to find a more long-term solution to the problem, the committee heard much expert evidence on the feasibility of extinguishing or arresting the sparks before they were emitted into the open air. Robert Stephenson stated that his father, George Stephenson, ${ }^{25}$ had experimented with placing a 'bucket or reservoir of water at the bottom of the chimney'. ${ }^{26}$ Various contrivances were fitted in the smokebox in order to deflect the exhaust gases in such a way that the larger cinders would drop into the water and thereby be extinguished. Charles John Blunt described a technique used on some Belgian locomotives using sponges placed in the chimney and kept saturated with water ${ }^{27}$ However, most devices simply consisted of a wire mesh or gauze designed to catch or arrest the sparks in the same manner as a fireguard placed in front of a domestic fire. The problem with such devices, known as spark arrestors, was that they were prone to interfere with the draft of the locomotive and impair its performance. Numerous experiments were underway to determine how fine the mesh could be made and how to position the device so as to minimise interference with the draft. Some devices were placed over the top of the funnel as a cap and others were placed inside the funnel or in the smokebox. ${ }^{28}$

As regards the extent to which such devices had been put into use on a daily basis there was little consistency amongst the railway companies; although this is hardly surprising given the infancy of the technology. George Rennie ${ }^{29}$ stated that the Liverpool and Manchester Railway Co had enjoyed some

\footnotetext{
21 ibid 44-45.

${ }^{22}$ Isambard Kingdom Brunel needs little introduction as one of the fathers of the railways and provides the iconic image of Victorian engineering prowess. He had a mastery of both the civil and mechanical aspects of railway engineering. Leading biographies include LTC Rolt, Isambard Kingdom Brunel (rev edn, Penguin 1990).

${ }^{23}$ Select Committee on Locomotive Engines Used in Narrow Streets (n 20) 69.

24 ibid 70

25 The father and son duo of George and Robert Stephenson sit alongside Brunel as fathers of railway engineering and are normally mentioned in the same breath. In common with Brunel both had a mastery of both the mechanical and civil engineering aspects of the technology. See LTC Rolt, George and Robert Stephenson: the Railway Revolution (first published 1960, Amberley 2009).

${ }^{26}$ Select Committee on Locomotive Engines Used in Narrow Streets (n 20) 23.

27 ibid (37)

${ }^{28}$ The engineering press was already replete with articles and letters on the subject of spark arrestors, including a suggested design which was submitted by WS Grey in direct response to the testimony of Robert Stephenson before the 1836 Select Committee: See Mechanics Magazine 705 (Saturday 11 February 1837) 375.

${ }^{29}$ George Rennie (1791-1866) was another of the all-time great engineers of the pioneering days of steam. Whereas George Rennie specialised in mechanical engineering, his brother, John, was equally famed for his expertise in civil engineering. In this respect they formed an ideal partnership for working on railway projects.
} 
success in using the devices in regular service ${ }^{30}$ However, as the evidence of Dr Lardner ${ }^{31}$ indicated, in doing so the company had been motivated by the need to protect valuable cargo carried on its trains rather than a desire to protect lineside property.$^{32}$ One of the mainstays of the company's business was the transportation of bales of cotton from the Port of Liverpool to the cotton spinners in Manchester. The loads were carried on open wagons and covered in tarpaulins which, as can readily be discerned from the word, were waterproofed with combustible tar at that time. ${ }^{33}$ On more than one occasion locomotives had set fire to their own cargoes of cotton and even silk at great expense to the carrier and its insurers.

Dr Lardner ascribed the fires caused by the Stockton and Darlington to the fact that it still used its older 'very rough engines' on coal trains which were not fitted with any form of spark arresting device. ${ }^{34} \mathrm{He}$ also noted that locomotives on the Leicester and Swannington Railway were particularly prone to causing lineside fires spreading to agricultural land. It had not been possible to fit spark arrestors to funnels of locomotives because of the low height of a tunnel. ${ }^{35}$ Moreover, they fired their locomotives with Leicestershire coal, which was 'of extremely peculiar quality' containing a great deal of sulphur and other undesirable elements. ${ }^{36}$

However, the main reason why spark arrestors had yet to be widely adopted concerned the difficulties of overcoming their deleterious effect on the performance of locomotives. Hardman Earle, a director of the Liverpool and Manchester Railway, acknowledged the aforementioned difficulties the company had experienced with locomotives setting fire to valuable cargoes. He seemed rather less concerned about lineside fires and damage to other property and cautioned against the adoption of unduly onerous obligations. Whilst he was prepared to accept in principle some form of technical requirement to fit spark arresting devices, they "must not be incompatible with the performance of the engine' ${ }^{37}$

Notwithstanding the plethora of evidence on technical solutions to the railway sparks issue, the committee concluded that no device was yet available which could reduce the risk caused by sparks without unduly impairing the performance of engines. Thus, the committee decided not to recommend any legislation requiring the installation of devices. Instead, the committee concluded that legislation should be brought in requiring all railway companies to pay compensation for fire damage 'by a short and unexpensive process', and that this would incentivise the railway companies to 'take every precaution in their power, and to avail themselves of any invention which might tend to increase that security from fire which the public are entitled to expect ... ${ }^{38}$ In other words, rather than imposing a

\footnotetext{
Moreover, their heritage was impeccable in that they were the sons of the illustrious Scottish civil engineer, John Rennie (the elder) (1761-1821): see Andrew Saint and Mike Chrimes, 'Rennie, George (1791 - 1866)', Oxford Dictionary of National Biography (3 October 2013) <https://doi.org/10.1093/ref:odnb/23374> accessed 26 June 2019.

${ }^{30}$ Select Committee on Locomotive Engines Used in Narrow Streets (n 20) 5.

${ }^{31}$ Dionysius Lardner (1793-1859) was one of the early academic engineers and scientists who wrote on science and engineering matters and gave many public lectures: Henry Boylan, A Dictionary of Irish Biography (Gill and MacMillan 1998) 215.

${ }^{32}$ Select Committee on Locomotive Engines Used in Narrow Streets (n 20) 10.

${ }^{33}$ See RHG Thomas, The Liverpool and Manchester Railway (Harper Collins 1980) 201-05.

${ }^{34}$ Select Committee on Locomotive Engines Used in Narrow Streets (n 20) 11.

35 ibid. This would have been the Glenfield Tunnel, built by George and Robert Stephenson, which was the longest railway tunnel to have been built at the time. Difficult geological conditions led to delays and cost overruns, and it was necessary to install exceptionally thick tunnel linings to contain the running sand. This may have accounted for the reduced height of the tunnel. See 'Glenfield Tunnel' <http://www.storyofleicester.info/city-heritage/built-heritage-continued/glenfield-tunnel/> accessed 7 February 2018.

${ }^{36}$ Select Committee on Locomotive Engines Used in Narrow Streets (n 20) 10.

37 ibid 74.

38 ibid a 2.
} 
'top-down' technical requirement, it was proposed that the law should be applied in such a way that the railway companies would be incentivised to find a 'bottom-up' engineering solution.

Although legislation of this nature never materialised, the findings of the 1836 Lords Select Committee may have influenced the drafting of the aforementioned London Grand Junction Railway Bill, which, as previously noted, led in part to the instigation of the committee. The Act which emerged $^{39}$ provides an isolated example of a railway act which expressly rendered the railway company liable and stipulated the need for spark arrestors to boot; although it is important to note that the line was never actually built (for reasons elucidated below). As previously stated, the project would have extended the London and Birmingham Railway along a 2-mile viaduct from Euston into the heart of the city. ${ }^{40}$

Section 104 of the Act was a 'nuisance clause' which would have precluded the statutory powers from overriding the common law insofar as lineside fire damage was concerned stating that "nothing in the Act contained shall be construed to relieve the Company from any responsibility for damage by fire or otherwise, to which they would be subject by Common Law'.

In this respect the provision would have prevented the statutory authority defence, which is dealt with in detail below, from operating. As regards the need to fit spark arrestors, section 187 provided as follows:

And for the further protection of persons and property residing and being on the line of the said Railway, be it enacted, that every such engine which shall at any time hereafter be brought upon or used on the said Railway shall have a proper and well secured hood or cover of wire gauze (the width of the spaces between the wires of which shall not be more than one eighth of an inch from each other) affixed upon the top of the shaft of the chimney thereof, and that no such engine shall at any time be brought upon or used on the said Railway, unless the same shall have first affixed thereon such hood or cover as aforesaid.

Such stipulations were normally only imposed on locomotives working in dockyards and so forth in order to protect the warehouses and merchandise therein. ${ }^{41}$ It might well be the case that such a provision was included in the London Grand Junction Act due to the proximity of high-value real estate which the line would have passed through. Moreover, it would have terminated in a warehousing and commercial district around Skinner Street, which was akin to a dockyard area.

The scheme was promoted by speculators who were not actually part of the London and Birmingham Railway and clearly banked on the fact that they would be able to sell the line to the company at a huge profit once built. However, the project encountered financial difficulties from the outset and remarkably stiff opposition from the city real estate owners, the very reason why the major railway companies all stopped short of the city in the first place. In fact, the dubious cost estimates and extravagant claims ${ }^{42}$ led to the line being dubbed 'the Humbug' by the London business fraternity. ${ }^{43}$ This scepticism proved well founded in that work was delayed as the promoters continued to struggle to raise funds. An especially disgruntled objector, Robert McWilliam published lengthy correspondence in which he made allegations tantamount to fraud on the part of the promoters

\footnotetext{
${ }^{39}$ London Grand Junction Act 1836 (6 \& 7 Will 4 c 104).

${ }^{40}$ An artist's impression of how the Skinner Street terminus would have looked was produced by George Remington Junior in 1835. See Museum of London <http://www.museumoflondonprints.com/image/142066/birds-eye-view-of-the-london-grand-junction-railway1846> accessed 13 September 2018.

${ }^{41}$ For an example of a locomotive designed for working in such environments, see Hugh Moffat, East Anglia's First Railways (Terence Dalton 1987) 114.

${ }^{42}$ Many of which were set out in a pamphlet published by an unnamed promoter: By a Proprietor, London Grand Junction Railway: A Review of its Prospects and Utility (2nd edn, Effingham Wilson, Royal Exchange London 1837).

${ }^{43}$ See 'The Mirror of Parliament' (Sess 1837-38) vol v (April 26) 3540-41.
} 
together with claims of harassment and bullying of opponents. ${ }^{44}$ Part of his case was that the prospectus dramatically underestimated the liabilities of the railway, especially the cost of fire damage. The aforementioned provisions were cited as evidence of the extent of the company's potential liabilities. In addition, McWilliam somewhat gleefully referred to the House of Lords Select Committee recommendations ${ }^{45}$ as proof that the direction of travel of the law was very much in favour of imposing such costs on the railway industry. Having made next to no progress in the two years which followed the enactment of the 1836 Bill, the promoters returned to Parliament with a second Bill seeking time extensions and the ability to implement financial restructuring. The Bill appears not to have progressed beyond the committee stage following second reading..$^{46}$ In any event the project foundered and the line was never built.

Although the 1836 Lords' Select Committee proposals ${ }^{47}$ were not acted upon at the time, within a few years a further opportunity to legislate upon the matter presented itself. Throughout the $1830 \mathrm{~s}$ the nascent railway system grew at an exponential rate. ${ }^{48}$ The new phenomenon of the railway accident highlighted the dangers of the technology, and the interests of passengers were not always high on the agendas of the railway companies. It became clear that some form of belated top-down governmental regulation was necessary in the interests of public safety and to improve the comfort and convenience of passengers. ${ }^{49}$ To this end the first Railway Regulation Act of $1840^{50}$ was passed, which established the Board of Trade as the railway regulator and bestowed it with certain limited powers. However, the number and severity of railway accidents continued to grow as exemplified by the Sonning Hill cutting disaster of Christmas Eve 1841 in which eight passengers died when a train ploughed into a landslip. ${ }^{51}$ By this time William Gladstone had been appointed as Vice-President of the Board of Trade, and he immediately took a keen interest in railway affairs. The Sonning accident may in part have influenced Gladstone's decision to bring forward a new Bill in early 1842 which sought to augment the existing legislation..$^{52}$ This culminated in the Railway Regulation Act $1842,{ }^{53}$ which was still rather light-touch in its approach.

\footnotetext{
44 The main correspondence was published in two bound volumes: one was addressed to the members of the House of Lords Select Committee, which had reviewed the Bill, and the other especially virulent set of correspondence was addressed to one Robert Hay Graham MD, a director of the company. See Robert McWilliam, London Grand Junction Railway, surnamed the Humbug: a letter to the Most Noble John, Duke of Bedford, the Most Noble John, Marquis of Camden, Right Honourable Charles, Lord Southampton, Right Honourable George Lord Calthorpe (RS Kirby, 20 Warwick Lane London 1838): Robert McWilliam, London Grand Junction Railway, surnamed the Humbug: Second Letter to Robert Hay Graham MD (RS Kirby, 20 Warwick Lane London, 1837).

${ }^{45}$ Select Committee on Locomotive Engines Used in Narrow Streets (n 20).

${ }^{46}$ See 'The Mirror of Parliament' (n 43).

${ }^{47}$ Select Committee on Locomotive Engines Used in Narrow Streets (n 20).

${ }^{48}$ All the Bills establishing the main bones of the mainline network as we still know it today were passed by Parliament between 1833 and 1836. See Christian Wolmar, Fire and Steam: How the Railways Transformed Britain (Atlantic Books 2007) 61.

${ }^{49}$ See Frederick Clifford, A History of Private Bill Legislation: volume 1 (first published 1885, Routledge 1968) 95.

503 \& 4 Vict c 97.

${ }^{51}$ See Michael Foley, Britain's Railway Disasters: Fatal Accidents from the 1830s to the Present Day

(Wharncliffe Transport 2013) 33-35.

${ }^{52}$ See Hiroki Shin, 'Have Consumer Movements Enhanced Transport Justice? Passenger Representation on Britain's Railways Before 1947' in Colin Divall, Julian Hine and Colin Pooley (eds), Transport Policy: Learning Lessons from History (Routledge 2016) 80.

$535 \& 6$ Vict c 55 .
} 
During the course of parliamentary proceedings on the 1842 Bill, ${ }^{54}$ Lord Howick ${ }^{55}$ drew Gladstone's attention to the fact that a court had recently decided that railway companies were not liable in respect of fire damage caused by sparks emitted by locomotives. ${ }^{56}$ Although the case was not referred to by name, there is a strong possibility that it was Aldridge $v$ Great Western Rly $\mathrm{Co}^{57} \mathrm{a}$ decision of the Court of Common Pleas from the previous year. As will be seen below, the case established that negligence would have to be shown in order to establish liability on the part of the railway company. Lord Howick argued that the opportunity should be taken to insert a new clause into the Bill rendering the railway companies liable for this type of loss. Gladstone accepted that 'the subject was deserving of consideration' but doubted that the legal position was as clear cut as Lord Howick had asserted. ${ }^{58}$ This was borne out by the fact that Robert Palmer (the Member for Berkshire) was able to refer to a case in which the Great Western Railway had in fact paid compensation ${ }^{59}$ although he did not specify whether or not this was as a result of private ordering as opposed to a judicial pronouncement. Lord Howick pressed the argument again the following week at third reading of the Bill. He expressed dismay at the fact that Gladstone had not sought to clarify the legal implications of the court's decision in order to assess the necessity of a new clause. Moreover, he had been left with the impression that Gladstone was broadly in favour of adopting some form of measure. ${ }^{60}$ Gladstone denied that he had given any form of undertaking on the issue on the previous Saturday. He also intimated that Board of Trade lawyers had in fact looked at the issue and reached a conclusion that 'was contrary to that of the noble Lord on the subject'. It has not been possible to discover a record of the specific advice; however, as will be seen, the need to show negligence would not necessarily have let the railway company off the hook in the manner that Lord Howick appeared to suggest. Gladstone rejected a plea to postpone the passage of the Bill for two days to enable further research to be conducted. ${ }^{61}$

The exchange between William Gladstone and Lord Howick indicates that, at the very least, the common law position was unclear, and this in itself could have justified clarification of the legal position by way of statutory intervention. However, imposing strict liability, for example, would have proved extremely controversial and would have met with fierce resistance from railway interests. Gladstone seems to have been aware of the fact that it was far too late to open up such a major issue for debate and emphasised the fact that many great projects could not be undertaken until the Bill had been enacted. ${ }^{62}$ On a broader level it seems that railway sparks was regarded as a 'side issue' not fitting with the main theme of the Bill, which concerned the safety and convenience of the travelling public or those who might be directly endangered on crossings and so forth. ${ }^{63}$ This coloured the attitude of the Board of Trade and subsequent rail regulators until the demise of steam 120 years later.

\footnotetext{
${ }^{54}$ The proceedings in question occurred on 18 June 1842, when the House of Commons resolved itself into a Committee on the Bill and the debate on third reading of the Bill on 24 June 1842. The 18 June proceedings are recorded in The Railway Times no 234 vol 5(26) (25 June 1842) 656-57 and the proceedings of the 24 June are recorded in The Railway Times no 235 vol 5(27) (2 July 1842) 682. As regards the 18 June proceedings, see also Hansard HC Deb 18 June 1842, vol 64, cols 173-95. As regards the proceedings of 24 June, Hansard merely records the fact that the Bill was passed at third reading: HC Deb 24 June 1842, vol 64, col 550. The report in the Times carries an inadequate account of the debate and misses the key exchanges between Lord Howick and Gladstone: The Times (London, 25 June 1842) 3. Thus the Railway Times carries the only complete account of the debate.

${ }^{55}$ Henry Grey, 3rd Earl Grey (1802-94).

56 See Hansard (18 June 1842) (n 54) cols 194-95.

57 (1841) 3 Man \& G 515, 133 ER 1246.

58 See Hansard (18 June 1842) (n 54) col 195.

59 ibid.

${ }^{60}$ See Railway Times (25 June 1842) (n 54) 682.

61 ibid.

62 ibid.

${ }^{63} \mathrm{ibid}$. This is apparent from the contributions of several members, each of whom displayed irritation at the loading of the Bill with additional clauses, many of which did not reflect the preamble of the Bill and its emphasis on public safety and the comfort and convenience of passengers.
} 
At no point did a regulator make any serious attempt to get to grips with the problem or even acknowledge its magnitude.

As will be seen below, legislation on the liability of railway companies for fire damage caused by sparks was not forthcoming until 1905, and only then in a very weak and limited form. In the meantime, as the aforementioned decision of Aldridge indicates, it was left entirely to the common law to settle such claims.

\section{KEY DOCTRINAL DEVELOPMENTS IN THE COMMON LAW}

\section{A. Statutory authority}

The railway sparks cases must be set against the backdrop of a significant case law development which occurred at the dawn of the railway revolution. However, the case concerned spooked horses rather than lineside fires. In $R v$ Pease $^{64}$ the enginemen and directors of the Stockton and Darlington Railway were indicted in public nuisance following a number of incidents in which horses had been startled by locomotives on a section of track which ran alongside the Yarm turnpike. Carriages and wagons were overturned and those on horseback were bolted off with. ${ }^{65}$

The railway had originally been conceived of as a horse-drawn wagon way and was authorised by way of a private Act of Parliament on this basis. ${ }^{66}$ However, following a famous meeting between the lead promoter, Edward Pease, and the legendary George Stephenson, it was agreed that at least some of the motive power should be provided by steam locomotives. Stephenson, who was not involved in the project from the outset, also persuaded Pease that there should be some alterations to the alignment of the route. This necessitated submitting a second private Bill to Parliament. ${ }^{67}$ The solicitor to the Stockton and Darlington Railway, Francis Mewburn, ${ }^{68}$ had the foresight to insert a new clause expressly authorising the use of steam locomotion. This was enacted as section 8 of the second Stockton and Darlington Railway Act ${ }^{69}$ and proved instrumental in terms of the development of the statutory authority defence.

In the Court of King's Bench, Parke J held that the Acts of Parliament which authorised the acquisition of land and the construction and operation of the line empowered the company to cause some losses which would otherwise constitute actionable nuisances. This was based on the assumption that a railway cannot be built and operated without causing some harm, and Parliament would not have granted the powers if it did not intend such harm to be caused. Moreover, it could also be assumed that Parliament had weighed the competing interests and deemed the losses caused to local inhabitants to be a price worth paying for the wider public benefits of the scheme.

On the face of it Parke J's judgment was exceedingly generous to the defendant in that he asserted that section 8 of the Act did not impose any qualifications on the manner in which the locomotives should be used. However, a closer reading of the case reveals that it is imbued with the need to avoid causing unnecessary harm. Pollock, for the defence, stressed that the company had 'exercised their power so as to cause the least possible inconvenience, by using engines of the best construction' ${ }^{70}$ It would be stretching credulity to suggest that Parliament would have granted powers enabling

\footnotetext{
64 (1832) 4 B \& Ad 30, 110 ER 366.

${ }^{65}$ For a historical account of the case (including a more detailed description of the carnage on the Yarm turnpike) and its role in shaping the defence of statutory authority, see Mark Wilde and Charlotte Smith, 'R v Pease' in Charles Mitchell and Paul Mitchell (eds), Landmark Cases in the Law of Tort (Hart 2010).

$661 \& 2$ Geo 4 c 44.

${ }^{67}$ See WW Tomlinson, The North Eastern Railway: Its Rise and Development (Longmans, Green \& Co 1915) 60-87. MW Kirby, The Origins of Railway Enterprise: The Stockton and Darlington Railway 1821-1863 (CUP 1993) ch 3.

68 ibid. Mewburn has been described as 'the first railway solicitor'.

${ }^{69} 4$ Geo 4 c 33 .

${ }^{70}$ Pease (n 64) 4 B \& Ad 30, 39; 110 ER 366, 370.
} 
unnecessary harm to be caused through carelessness. As we shall see, subsequent cases refined the idea that only unavoidable or inevitable harm would be covered by the defence. Harm caused by negligence is, a fortiori, avoidable and hence outwith the scope of statutory powers.

\section{B. Trespass and case}

The earliest railway sparks case to feature in the law reports is Aldridge v Great Western Railway Co ${ }^{71}$ which concerned the destruction by fire of a stack of beans in a field at Burnham,

Buckinghamshire. As noted above there is a possibility that this is the case which was referred to in the exchanges between Lord Howick and Gladstone during the passage of the 1842 Railway

Regulation Bill. It will also be recalled that, according to evidence supplied by Brunel to the 1836

House of Lords' Select Committee on railway fires, ${ }^{72}$ the railway companies had been accustomed to making out-of-court settlements. By the 1840s it seems that the Great Western Railway Co (GWR) felt that it was necessary to test the extent of its legal liabilities and chose to contest the claim. The case quickly exposed the limitations of trespass as a viable cause of action.

The standing crops had been set alight by a spark from a locomotive passing along Brunel's recently opened broad gauge mainline to Bristol; a case was stated for the opinion of the court. In the Court of Common Pleas, counsel for the plaintiff, Serjeant Channell, constructed a complex argument which sought to negotiate the arcane rules relating to the boundaries between the forms of action. ${ }^{73} \mathrm{He}$ argued that an action in trespass could have been brought against the enginemen who operated the locomotive. However, it was well established that trespass could not be brought against the master of a servant in respect of a wilful act on the part of the servant. ${ }^{74}$ The action had to be brought in case and framed in terms of negligence. Thus, it was necessary to show that the GWR could be liable in respect of a non-wilful act on the part of the enginemen. However, he sought to blur the distinction between trespass and case by asserting that there were many instances in which one could be held liable in trespass for non-wilful acts; in which case the employer could be held accountable. ${ }^{75}$ It is clear that Channell was reaching for some idea of strict liability, although he clearly struggled to conjure it out of the constraints of the forms of action. By this device he sought to put the defendant on the back foot by putting the onus on them to show that the harm could not have been avoidedthus importing the concept of 'inevitable accident' from trespass. He was interrupted many times by the judges whilst attempting to make his submissions and appears to have been blown off course somewhat, making his line of reasoning very difficult to follow.

Serjeant Bompas, for the defendant, argued that the claim was framed in terms of negligence and 'the onus does not lie on the defendants to disprove it' ${ }^{76} \mathrm{He}$ also recognised the potential role that

\footnotetext{
71 (1841) 3 Man \& G 515, 133 ER 1246.

72 (n 24).

${ }^{73}$ Aldridge (n 71) 3 Man \& G 515, 519-22; 133 ER 1246, 1248-49.

${ }^{74}$ In order to bring an action in trespass against the master, it would be necessary to show that the master expressly commanded the servant to commit the trespass or the trespass was the inevitable result of a command. See McManus $v$ Crickett (1800) 1 East 106, 102 ER 43. There was no discussion in Aldridge as to whether the throwing of the sparks was an inevitable consequence of being commanded to drive a steam locomotive.

75 These cases occupied a grey area between wilful acts, which clearly sounded in trespass, and negligent acts, which clearly sounded in case. The overlap was most pronounced in the 'running down' cases where the issue seemed to turn upon whether the defendant's actions were the direct and immediate cause of the harm-in which case trespass could be maintained notwithstanding that the act was not wilful. Otherwise it would be necessary to show negligence and bring the action in case: see MJ Prichard, 'Trespass, Case and the Rule in Williams v Holland' (1964) 22 CLJ 234. However, it is important to note that there was no clear boundary between negligence and strict liability, and the standard of liability was often determined by categories of cases rather than overarching principles. See John Baker, The Oxford History of the Laws of England: vol VI $1483-$ 1558 (OUP 2003) ch 41. In some cases the fault appeared to reside in merely undertaking an activity, even though, on the face of it, the activity was not proscribed by law. It might be the case that Channell was attempting to establish railway fires caused by stray sparks as such a category. As shall be seen below, the idea was later taken up by Baron Bramwell.

${ }^{76}$ Aldridge (n 71) 3 Man \& G 515, 522; 133 ER 1246, 1249.
} 
Pease could play in terms of limiting the liability of railway companies for fire damage. He argued that, in the absence of negligence, the defendant could not be liable for any damage arising from the use of its statutory powers. ${ }^{77}$

The judge, Tindal CJ, was also clearly of the opinion that the boundaries between negligence and trespass could not be blurred in the manner proposed by Channell. ${ }^{78}$ In order to bring a claim against the master, the matter would have to be examined through the lens of negligence and the concept of 'inevitable necessity' (or inevitable accident) would play no part.

Where a servant drives his master's carriage against the carriage of another trespass might be brought against the servant and inevitable necessity would form the only excuse. But if an action on the case be brought against the master the inquiry has always been not whether the injury was the result of inevitable necessity but of negligence on the part of the servant. ${ }^{79}$

This led to the conclusion that a jury should be asked to consider whether there had been negligence in terms of the manner in which the locomotive had been driven or wider issues relating to how the railway had been operated.

At first blush the case appears to have been a victory for the railway company, which was able to fend off a stricter form of liability in favour of negligence. Assuming that the case was the one which Lord Howick had in mind in his exchanges with Gladstone, ${ }^{80}$ it may explain why he felt that the case would greatly reduce the liability of railway companies for fire damage. However, the picture was in fact far less clear cut. Notwithstanding the fact that, in an action on the case for negligence, concepts such as 'inevitable necessity' could not be used to shift the onus onto the defendant to exculpate himself, there remained the issue of res ipsa loquitur. Although the doctrine has been much derided in the twentieth century, ${ }^{81}$ in the nineteenth century there was still a strong sense that certain factual circumstances would call for a clear explanation on the part of the defendant. Otherwise, the court would be in a position to draw an inference that there must have been a breach of duty. In Aldridge the concept was strongly alluded to by Maule $\mathrm{J},{ }^{82}$ who cited Christie $v$ Griggs $^{83}$ in which a passenger on a stage-coach was injured when the axle snapped, '[I]t was held, that proof of the coach having broken down was prima facie evidence, from which the negligence would be inferred' ${ }^{84}$

Maule $\mathrm{J}$ returned to this theme in the next major reported railway sparks case, which turned solely upon the issue of negligence.

\section{Negligence}

The case in question was Piggot $v$ Eastern Counties Railway $\mathrm{Co}^{85}$ which concerned substantial fire damage to farm buildings and the goods and chattels therein. Once again, the case fell before Tindal

\footnotetext{
77 ibid 3 Man \& G 515, 523; 133 ER 1246, 1249.

${ }^{78}$ The desire of the court to re-establish clearer boundaries between the forms of action may, in part, have been due to the changes to the pleading rules in Hilary Term 1834. This constituted a return to a more prescriptive and arcane mode of pleading which affected how arguments were framed in terms of the forms of action. See WS Holdsworth, 'The New Rules of Pleading of the Hilary Term 1834: Did they affect the Development of the Substantive Law?' (1923) 1 CLJ 261, 262: 'It was a branch of the law of procedure; and, since it was from the law of procedure and around the forms of action that the principles of the common law were being developed, and since the maintenance of these forms of action was, right down to the beginning of the nineteenth century, regarded as a vital necessity for the being of the common law, it is not surprising that a subject so intimately bound up with these forms of action should be regarded as equally necessary to its being'.

${ }^{79}$ Aldridge (n 71) 3 Man \& G 515, 521; 133 ER 1246, 1249.

${ }^{80}$ See references at $n 54$.

${ }^{81}$ See, for example, the comments of Morris LJ in Roe v Minister of Health [1954] 2 QB (CA) 66, 87.

${ }^{82}$ Aldridge (n 71) 3 Man \& G 515, 522; 133 ER 1246, 1249.

83 (1809) 2 Campb 79, 170 ER 1088.

${ }^{84}$ Aldridge (n 71) 3 Man \& G 515, 522; 133 ER 1246, 1249.

85 (1846) 3 CB 229, 136 ER 92.
} 
CJ, who noted that the legislature had entrusted the defendants "with an agent of an extremely dangerous and unruly character'. ${ }^{86}$ As such it was incumbent on the defendants to 'adopt such precautions as may reasonably prevent damage to the property of third persons through or near which their railway passes ${ }^{87} \mathrm{He}$ was persuaded by expert evidence to the effect that the only effective way of mitigating sparks was to fit spark arrestors, which were likened to muzzles fitted to dangerous animals. ${ }^{88}$ As will be seen below, the necessity of fitting spark arrestors dominated much of the subsequent case law. The failure of the railway company to fit such devices was regarded as constituting 'abundant' ${ }^{89}$ evidence of negligence.

Aside from the emergence of the spark arrestor issue, the Piggot case is significant because the bar was set relatively high in terms of what measures would be expected of the railway company in order to discharge the duty of care. Coltman J held that the setting alight of the buildings by sparks 'established a prima facie case of negligence, which called upon them to shew that they had adopted some precautions to guard against such accidents' ${ }^{90}$ Maule J adhered to the approach which he had adopted in Aldridge and stated that the evidence 'at least affords a strong presumption of negligence, in the absence of evidence to shew that something had been done by the company to lessen the chances of danger'. ${ }^{91}$ As has been noted in respect of Aldridge, these arguments appeared to place the onus on the railway company to show that it had taken due care and is redolent of res ipsa loquitur.

This 'strong presumption of negligence' arising from the ignition of material by stray sparks is clearly illustrated by two subsequent decisions of the Assize Courts. In Kent v Eastern Counties Railway ${ }^{92}$ a field of oats was destroyed having been set alight by sparks emitted by a passing engine. The case turned solely upon the issue of causation and the evidence of the only witness, a small boy. Serjeant Ballantine could not 'shake the boys evidence' and 'thought it would not be becoming to resist the claim any further'. He submitted a verdict of $£ 137$ ss. The Piggot decision suggested that fitting spark arrestors was a prerequisite to discharging the duty of care. Given that the railway company did not contest the case on the grounds that they had taken sufficient care, it seems unlikely that the locomotive had been fitted with such devices in this case. ${ }^{93}$ In Gibson v South Eastern Railway ${ }^{94}$ a plantation of young fir trees on land owned by Robert Gibson, of Sandhurst Lodge near Wokingham, were destroyed by fire. Witness testimony established that the fire was caused by sparks from a passing locomotive, and this alone was deemed as sufficient evidence of negligence. Once again, the reports of the case do not indicate any attempt to defend the action on the basis that sufficient care had been taken. Most of the argument was taken up with the valuation of the property destroyed.

By the close of the 1850s, it seems that the mere emission of sparks causing fire damage would give rise to a presumption of negligence and the only way to rebut this presumption would be to fit spark arrestors. In the next decade it fell to be determined whether the short hop should be made from the imposition of an onerous duty of care to strict liability. The issue came to a head in a watershed case law development.

\footnotetext{
86 ibid, 3 CB 229, 240; 136 ER 92, 96.

87 ibid, 3 CB 229, 240; 136 ER 92, 97.

88 ibid, 3 CB 229, 241; 136 ER 92, 97.

${ }^{89}$ ibid, 3 CB 229, 240; 136 ER 92, 97.

90 ibid, 3 CB 229, 241-242; 136 ER 92, 97.

91 ibid, 3 CB 229, 242; 136 ER 92, 97.

92 'Railway Intelligence' Hampshire Advertiser and Salisbury Guardian (Southampton, 26 February 1859) 7.

93 This is borne out by what we know of the design of Eastern Counties Railway locomotives at this time. They were certainly not fitted with spark arrestors as a matter of routine, and the only known locomotives to be equipped with such devices were those which worked in London's docklands where there was a need to protect valuable merchandise. See Moffat (n 41).

94 (1858) 1 F \& F 23, 175 ER 608.
} 


\section{The rise and immediate fall of strict liability for railway sparks}

The litigation in question, Vaughan $v$ Taff Vale Railway Co, stemmed from an incident in which eight acres of woodland were destroyed by fire caused by sparks from a locomotive on the Aberdare branch. There had been several fires since the branch opened, and the company had made a number of payments in the past to the landowner. In the Court of Exchequer, ${ }^{95}$ Bramwell B upheld his own ${ }^{96}$ jury direction to the effect that the defendant could be liable in negligence, notwithstanding the fact that it had taken all reasonable steps to mitigate the risk of sparks in terms of the design of the engine. It was accepted that 'everything practicable had been done to the locomotive to make it safe' ${ }^{97}$ As Atiyah noted, 'to a modern lawyer Bramwell's judgment looks confused and difficult to follow' in that the finding that all due precautions had been taken conflicts with a finding of negligence..$^{98}$ In fact, as Atiyah correctly asserted, the judge was attempting to establish strict liability and the reasoning needs to be elucidated.

In their submissions for the plaintiff, Grove and Giffard drew an analogy between the operation of a steam locomotive and the keeping of a dangerous animal such as a tiger. A person keeping an animal of this nature 'is bound to secure it at his peril and if it does mischief negligence is presumed' ${ }^{99}$ Bramwell B held that if, despite taking every practicable precaution, lineside fires still occurred as 'one of the habitual incidents to the use of the locomotive', ${ }^{100}$ the mere use of such machines could be regarded as inherently dangerous and thus blameworthy. This aspect of the case foreshadowed the emergence of a more generalised concept of strict liability in Rylands $v$ Fletcher a few years later. The Rule in Rylands $v$ Fletcher has vexed scholars for many years in that it is difficult to understand how a rule of strict liability emerged from an action on the case for negligence. ${ }^{101} \mathrm{FW}$ Pollock sought to explain strict liability on the grounds that it collapses the distinction between the nature of the activity and the manner in which the activity is conducted:

The law might have been content with applying the general standard of reasonable care, in the sense that a reasonable man dealing with a dangerous thing - fire, flood-water, poison, deadly weapons, weights projecting or suspended over a thoroughfare, or whatsoever else it be-will exercise a keener foresight and use more anxious precaution than if it were an object unlikely to cause harm, such as a faggot, or a loaf of bread. A prudent man does not handle a loaded gun or a sharp sword in the same fashion as a stick or a shovel. But the course adopted in England has been to preclude questions of detail by making the duty absolute; or, if we prefer to put it in that form, to consolidate the judgment of fact into an unbending rule of law. ${ }^{102}$

It is significant that Bramwell B was also involved in the Rylands litigation and, as Atiyah has pointed out, 'was the only judge in the Court of Exchequer to decide the case in the same way that the House of Lords ultimately did'. ${ }^{103}$ One can see FW Pollock's explanation of the reasoning behind Rylands at work in Bramwell B's approach to the Vaughan case in that, if the fire risk associated with running steam locomotives could not be sufficiently mitigated, then operating those locomotives

\footnotetext{
95 (1858) 3 Hurl \& N 743, 157 ER 667.

96 Thanks to the niceties of nineteenth-century legal procedure, it was not unusual for a judge to preside over a challenge to one of his own findings or directions in that judges of the higher courts would often also serve as trial judges.

97 (1858) 3 Hurl \& N 743, 750; 157 ER 667, 670.

98 PS Atiyah, 'Liability for Railway Nuisances in the English Common Law' (1980) 23 JL \& Econ 191, 192.

${ }^{99}$ (1858) 3 Hurl \& N 743, 747; 157 ER 667, 669.

100 (1858) 3 Hurl \& N 743, 751; 157 ER 667, 670.

${ }^{101}$ In recent years Newark's 'offshoot theory', according to which Rylands branched off from nuisance as a means of dealing with sudden and accidental escapes as opposed to an ongoing state of affairs, has gained much currency in the courts: see FH Newark, 'The Boundaries of Nuisance' (1949) 65 LQR 480. However, the theory has been heavily criticised by Nolan, who notes that nuisance was not referred to in the litigation: see Donal Nolan, 'The Distinctiveness of Rylands v Fletcher' (2005) 121 LQR 421.

${ }^{102}$ F Pollock 'Duties of Insuring Safety: The Rule in Rylands v Fletcher' (1886) 2 LQR 52 (emphasis added).

103 Atiyah (n 98) 192.
} 
could not be regarded as a legitimate use of the defendant's land. The defendants countered that they had the authority of section 86 of the Railway Clauses (Consolidation) Act 1845 and cited $R v$ Pease in support. ${ }^{104}$ The argument was rejected by Bramwell B on the grounds that Parliament would never have intended to give 'the railway company a right to throw lighted coals on adjoining land. That would be a trespass'. ${ }^{105}$

Further insights into why Bramwell B was seemingly keen to ensure that the railway companies were held accountable for fire damage can be gleaned from comments he made in the case of Bamford $v$ Turnley. ${ }^{106}$ Although Bramwell B did not refer to Vaughan by name, he used the example of a woodland destroyed by fire, and there can be no doubt that he had the case in mind. Whilst he acknowledged the public benefits of railways, he emphasised that they must be able to 'pay their expenses', which included the cost of burning down a wood. A failure to impose such costs on the railways would undermine the public benefit justifications for building them. ${ }^{107}$ This is redolent of an economic cost internalisation approach. However, whilst Simpson acknowledged that Bramwell B had an interest in economic theory, he cautioned against projecting a Chicago School mid-twentiethcentury economic analysis onto the case. He concluded that Bramwell was principally motivated by 'an ethical notion of fairness', according to which a company which benefits from pursuing an activity without paying for the collateral damage is 'unjustly enriched'. ${ }^{108}$

Whilst it would certainly be going too far to say that Bramwell was attempting to pursue some form of prochronistic normative economic analysis of tort, entirely dismissing all economic influences is somewhat assumptive. The judge's keen interest in economics is well documented and was far more than casual. ${ }^{109}$ Whilst one can never know the true workings of a judge's mind, it is safe to assume that a number of influences may be at work, and it seems unrealistic to assert that economic considerations played no part at all in his reasoning. Although a great advocate of the common law and its role in protecting individual liberty, ${ }^{110}$ Bramwell also fully acknowledged wider public interest considerations. Thus, he noted the problems of awarding injunctive relief in circumstances where it 'might put a stop to works of great value'. ${ }^{111}$ Here it might be better if 'the owner of the affected lands might be compelled to accept compensation, and the works thereby legalized' ${ }^{112}$ There are far too many inconsistencies in his judgments to say that he was pursuing an overtly economic agenda, and other factors often came to the fore. However, as McLaren put it in his seminal article on how the common law had to adapt to the new challenges posed by the industrial revolution, such theories were part of the 'intellectual baggage' of judges at the time. ${ }^{113}$

In any event, Bramwell B's decision was overturned by the Court of Exchequer Chamber, ${ }^{114}$ where the leading judgment was delivered by Cockburn CJ. In short, the Chief Justice held that Bramwell B had underplayed the significance of the statutory powers. He acknowledged that, where a person keeps a dangerous instrument, 'he will be responsible to those who are thereby injured,

\footnotetext{
1048 Vict c 20. This provision adopted the concept of statutory authority for unavoidable harm caused by steam locomotives, established in Pease (n 64), as a standard clause in railway Bills.

105 (1858) 3 Hurl \& N 743, 752; 157 ER 667, 671.

106 (1862) 3 B \& S 66, 85; 122 ER 27, 33.

${ }^{107}$ He made similar arguments in his opinion in Hammersmith \& City Railway v Brand (1869-70) LR 4 HL 171,

191 , in which damages were sought in nuisance in respect of vibration caused by passing trains.

108 Simpson (n 1) 173-75.

${ }^{109}$ See Atiyah (n 98) 191.

${ }^{110}$ See David Abraham, 'Liberty and Property: Lord Bramwell and the Political Economy of Liberal

Jurisprudence, Individualism, Freedom and Utility’ (1994) 23 AJLH 288.

${ }^{111}$ See Bamford $v$ Turnley (n 106) 3 B \& S 66, 86.

112 See Atiyah (n 98) 194.

113 John PS McLaren, 'Nuisance Law and the Industrial Revolution-Some Lessons from Social History' (1983)

3 OJLS 155, 192.

114 (1860) 5 Hurl \& N 679, 157 ER 1351.
} 
independently of any negligence in the mode of ... using the instrument' ${ }^{115}$ However, where an activity had been sanctioned by an Act of Parliament, $R v$ Pease had settled the law thus:

[W] hen the legislature has sanctioned and authorized the use of a particular thing, and it is used for the purpose for which it was authorized, and every precaution has been observed to prevent injury, the sanction of the legislature carries with it this consequence, that if damage results from the use of such thing independently of negligence, the party using it is not responsible. ${ }^{116}$

This constituted the clearest exposition of statutory authority to date and encapsulated all the key elements of the defence as we know it today. Cockburn CJ did not discount the possibility that operating steam locomotives could, at least in principle, give rise to strict liability. However, this could not be the case where statutory powers had been granted and due care had been taken to ensure that the powers did not cause gratuitous harm. ${ }^{117}$ Harm arising from negligence must have been avoidable and hence outside the scope of the statutory powers. Parliament would never sanction the careless use of any powers conferred.

The House of Lords endorsed the statutory authority defence in Hammersmith \& City Railway $v$ Brand $^{118}$ (concerning noise and vibration rather than sparks) in which Bramwell B's advisory opinion was rejected. ${ }^{119}$ Nevertheless, Bramwell B remained steadfast in his convictions throughout his judicial career and was unperturbed by the fact that he had been overturned in the Vaughan case and largely ignored in Brand. Some 20 years after Vaughan, sitting as one of the first Lord Justices of Appeal in the newly created Court of Appeal, he was presented with a final opportunity to reiterate his position on the railway sparks issue. In Powell $v$ Fall $^{120}$ an attempt was made to use the Locomotive Act $1861,{ }^{121}$ which regulated the use of road-going locomotives, to establish a statutory authority defence akin to that enjoyed by the railways. Predictably, Bramwell LJ (as he now was) would have none of it and heavily criticised those courts which had limited the liability of the railway companies:-

A great deal has been said about the liability of persons who have stored water which has subsequently escaped and done injury, and it has been urged that the emission of sparks from an engine is not so mischievous as the overflow of a large body of water. The arguments which we have heard are ingenious; but I need only say in reply to them that they have hardened my conviction that Rex v. Pease and Vaughan v. Taff Vale Ry. Co. were wrongly decided. $^{122}$

Bramwell LJ was alluding to the still relatively recent concept of strict liability forged by the celebrated case of Rylands $v$ Fletcher. As noted above, as Baron Bramwell, he had been the only judge in the Court of Exchequer decision in Rylands to argue in favour of strict liability on the basis that a man acts at his peril when he chooses to undertake certain activities, the approach ultimately

\footnotetext{
115 (1860) 5 Hurl \& N 679, 685; 157 ER 1351, 1354.

116 ibid.

${ }^{117}$ See also the judgment of Crompton $\mathbf{J}$ who rejected the dangerous animal analogy. Keeping a dangerous animal is negligent and hence constitutes unlawful conduct in itself without the need for any enquiry into how that risk was managed. Keeping and operating steam locomotives cannot be regarded as unlawful in that the defendant has the express authorisation of Parliament: see (1860) 5 Hurl \& N 679, 687; 157 ER 1351, 1355 (Crompton J).

${ }^{118}$ Brand (n 107).

119 The ability of the House of Lords to summon judges from the courts below to assist in the resolution of points of law by offering opinions was a long standing convention and survived the Civil Procedure Acts of 1852-54. The practice largely fell into disuse following the establishment of permanent appellate courts. For an analysis of the practice, see Van Vechten Veeder, 'Advisory Opinions of the Judges of England' (1900) 13 Harv L Rev 358.

${ }^{120}$ (1880) 5 QBD 597.

12124 \& 25 Vict c 70.

${ }^{122}$ Powell (n 120) 601.
} 
adopted by the House of Lords. ${ }^{123}$ As Bramwell LJ in the Court of Appeal he was clearly of the opinion that the operation of a steam locomotive ought to fall within the scope of the rule. The reason why he expressed such dissatisfaction with the authorities of Pease and Vaughan was that the concept of statutory authority established by those cases effectively prevented Rylands from being applied to steam locomotives. The manner in which this state of affairs came about requires some more detailed explanation.

\section{E. Rylands v Fletcher}

In a very brief judgment in Vaughan, one Blackburn $\mathrm{J}$ observed that the case distilled down to the issue of whether the defendants, notwithstanding the fact that they had 'adopted every precaution that science could suggest to prevent injury', ${ }^{124}$ could still be liable in negligence. 'That might have been a difficult question', ${ }^{125}$ he continued, 'but Rex v. Pease has settled that when the legislature has sanctioned the use of a locomotive engine, there is no liability for injury caused by using it, so long as every precaution is taken consistent with its use' ${ }^{126}$ A few years later Blackburn $\mathrm{J}$ cemented his place in legal history as the author of the rule of strict liability in Rylands $v$ Fletcher. ${ }^{127}$ His contribution to the Vaughan case is significant in that it shows that he was already beginning to marshal his thoughts on strict liability. In fact, in the immediate wake of the Rylands litigation, Blackburn J was presented with an opportunity to test his new rule of strict liability in a railway sparks case. In Jones v Festiniog Railway ${ }^{128}$ damages were sought in respect of the loss of a haystack and the building which housed it. In the Court of Queen's Bench, Blackburn J held that operating a steam locomotive on one's land, from which sparks and red hot cinders may escape, fell squarely within the recently established rule in Rylands $v$ Fletcher. However, in this case the defendant was offered no shelter by the statutory authority defence in that the Act of 1832, which authorised the construction of the line, made no reference to the use of steam locomotives. ${ }^{129}$

The Jones $v$ Festiniog case made it clear that, in the absence of statutory powers, the railway companies would be subject to strict liability for railway sparks. Indeed, road-going steam locomotives, which did not benefit from statutory powers, were subject to strict liability for fire damage. ${ }^{130}$ However, as regards the railways, the Jones case was the exception that proved the rule in that the vast majority of railway companies enjoyed the requisite statutory powers. Following the decision in Vaughan, most litigants were still faced with having to show negligence on the part of the railway companies.

\section{F. Negligence and statutory authority}

Thus, statutory authority preserved the need to establish negligence and prevented strict liability from operating in relation to railway fires - provided that the railway company enjoyed the requisite statutory powers. The position differed somewhat in respect of other types of harm, such as noise and vibration, which were actionable as private nuisances. ${ }^{131}$ In these cases negligence was not the cause of action; however, negligence in the broader sense of the term, as an adjective for describing fault as

\footnotetext{
${ }^{123}$ Fletcher v Rylands (1865) 3 Hurl \& C 774, 788-91; 159 ER 737, 743-44.

124 (1860) 5 Hurl \& N 679, 688; 157 ER 1351, 1357.

125 ibid.

126 ibid.

${ }^{127}$ Fletcher v Rylands (1866) LR 1 Ex 265, 279-80.

128 (1867-68) LR 3 QB 733.

1292 \& 3 Will 4 c 48. The Act only contemplated the use of stationary winding engines. Blackburn J adopted a narrow contra proferendem approach and found that locomotives were substantially different and thus not covered by the statute.

${ }^{130}$ See Watkins v Reddin (1861) 2 F \& F 629 and Powell (n 120). Spencer notes that the 'English courts came within a whisker' of imposing strict liability on automobiles powered by the new internal combustion engine: see JR Spencer, 'Motor Cars and the Rule in Rylands v Fletcher: A Chapter of Accidents in the History of Law and Motoring' (1983) 42 CLJ 65.

${ }^{131}$ See Hammersmith and City Railway (n 107), above.
} 
opposed to negligence as a tort, operated as a test for determining whether the defence was available. Harm resulting from fault must have been avoidable and hence outwith the scope of the statutory powers. Given that negligence in this context operated as a criterion for determining the availability of a defence, the evidential burden was shifted onto the defendant to disprove negligence. Moreover, as is apparent from the judgment of Lindley LJ in Shelfer $v$ City of London Electric Lighting Co, this was a heavy evidential burden to discharge: 'I will add further that it is clearly for the Defendants to prove, if they can, the truth of their assertion that it is impossible for them to carry on their business without creating a nuisance'. ${ }^{132}$

However, it is important to emphasise that private nuisance was never used in respect of railway sparks cases. ${ }^{133}$ Thus, negligence continued to operate as a tort in its own right as opposed to a test for determining the availability, or otherwise, of statutory authority. Thus, by the time the issue of railway sparks reached the House of Lords in Port Glasgow and Newark Sailcloth Co v Caledonian Rly Co ${ }^{134}$ (which shall be dealt with in more detail below in the context of spark arrestors), Herschell LC was in no doubt as to where the evidential burden lay: 'It is now well settled law that in order to establish a case of liability against a railway company in such circumstances it is essential for the pursuers to establish negligence'. ${ }^{135}$

Nevertheless, on occasion, the impression has been created that the railway sparks cases sounded in private nuisance. In Manchester Corporation v Farnworth, for example, Vaughan was mistakenly cited as a private nuisance case in the reported submissions made on behalf of the corporation. ${ }^{136}$ The characterisation of Vaughan as a nuisance case may in part stem from the heavy reliance upon Pease. Given that the Vaughan case concerned liability for individual losses, it is possible to gain the impression that the case concerned the extent to which the principles set out in Pease could be imported from public nuisance into private nuisance. For example, in his overview of the railway sparks cases, Morgan states that in Vaughan the plaintiffs 'tried to draw a distinction between public nuisance ... and private nuisance...' ${ }^{137}$ so as to prevent the doctrine formulated in Pease from leaping across into private nuisance.

In fact, the arguments to which Morgan alludes, namely the submissions made by Grove and Giffard on behalf of the plaintiffs, did not involve private nuisance at all. Rather, they concerned whether statutory authority could operate as a defence in respect of harms caused by activities subject to stricter forms of liability, such as the keeping of ferocious animals or the spread of fire. As noted above, these arguments were rejected by the Court of Exchequer Chamber in Vaughan. A steam

\footnotetext{
132 [1895] 1 Ch 287, 313 (emphasis added).

${ }^{133}$ One cannot be entirely certain as to why the potential of nuisance was not exploited in the context of railway sparks; this would have had the advantage of imposing a stricter standard of liability. However, it is possible to surmise that fires were regarded as isolated events rather than an ongoing state of affairs and thus fell outwith the scope of nuisance. Although he does not deal with the railway sparks cases directly, Nolan has offered a historical explanation as to why an ongoing state of affairs was deemed necessary in order to frame a case within the original forms of action dealing with nuisance: see D Nolan, 'The distinctiveness of Rylands $\mathrm{v}$ Fletcher' (2005) $121 \mathrm{LQR}$ 421, 437. Moreover, historically, fire damage was dealt with as a distinct form of liability and was not accommodated by forms of action concerning nuisance. Ogus noted that nuisance was not applied to a fire damage case until 1924: see AI Ogus, 'Vagaries in Liability for the Escape of Fire' (1969) 27 CLJ 104, 117. Latterly the case law has moved on and nuisance has often been used in respect of isolated events, thereby blurring any distinction with liability under Rylands v Fletcher. For a forcefully made argument against the need to maintain an 'ongoing state of affairs' criterion for nuisance, see Allan Beever, The Law of Private Nuisance (Bloomsbury 2014) ch 4.

134 (1893) $20 \mathrm{R}$ (Ct of Sess) (HL) 35.

135 ibid 36.

136 [1930] AC 171, 176.

137 Jonathan Morgan, 'Technological Change and the Development of Liability for Fault in England and Wales' in Miquel Martín-Casals (ed), The Development of Liability in Relation to Technological Change (CUP 2010) 43.
} 
locomotive could not be equated with a ferocious animal because the enabling legislation legitimised the activity.

On the face of it, those seeking to hold the railway companies accountable for the cost of fire damage, by way of action on the case for negligence, were at a distinct disadvantage vis a vis those suing for other types of loss in private nuisance. As noted above, in the context of nuisance, negligence shifted the evidential burden onto the defendant and established a higher duty of care by requiring him to show that the harm was unavoidable. Nevertheless, as the foregoing analysis demonstrates, the earlier railway sparks cases set the bar very high in terms of what constituted reasonable care. In addition, they appeared to adopt an approach based upon res ipsa loquitur, which put the onus on the defendant to justify, for example, the failure to fit spark arrestors. Thus, in this respect there was little practical difference in terms of the operation of negligence as an independent cause of action and as a test for determining the availability of statutory authority.

As regards establishing fault in individual cases, in some instances this was a relatively straightforward matter of fact to be put to the jury. Thus, in Smith $v$ London and South Western Railway ${ }^{138}$ for example, the railway company was clearly at fault in that it had left piles of highly combustible 'rummage' by the lineside for two weeks in exceptionally hot and dry conditions. The issues were far less clear where the evidence focused on technical issues relating to the design and operation of locomotives. These difficulties were crystallised by the question of whether or not spark arrestors should be routinely installed on locomotives. The aforementioned combination of a high standard of care and res ipsa loquitur should have levelled the playing field somewhat in terms of any imbalance in the expertise and resources of the litigants. However, as will be seen, this onerous interpretation of the duty of care in negligence was not sustained in subsequent case law developments.

\section{SPARK ARRESTORS-TO FIT OR NOT TO FIT?}

As we have seen, spark arresting devices emerged at a very early stage in the development of steam locomotive engineering. The simplest devices consisted of wire caps or 'bonnets' placed over the funnel. More sophisticated devices consisted of metal grids or mesh placed in the smoke box between the fire tubes and the base of the funnel.

Thus, the concept was very simple in that the grid or mesh simply caught lighted coals in the same manner as a fireguard placed in front of a domestic fire. It will be recalled that in Piggot $v$ Eastern Counties Railway Co, ${ }^{139}$ it was suggested that the absence of such devices would provide clear evidence of fault on the part of the railway company. However, one of the expert witnesses in the case, Professor Farey, acknowledged that spark arrestors could have a deleterious effect on the performance of locomotives by obstructing the draft, ${ }^{140}$ a drawback which was already well established as is evident from the proceedings of the 1836 House of Lords Select Committee on railway fires. ${ }^{141}$ For this reason, the railway industry opposed the fitting of such devices as standard and, as will be seen below, contested further attempts to establish that the fitting of spark arrestors was a prerequisite for discharging the duty of care.

\footnotetext{
138 (1869-70) LR 5 CP 98.

${ }^{139}$ Piggot (n 85).

${ }^{140}$ (1846) 3 CB 233, 234-35; 136 ER 92, 94-95. John Farey Jnr (1791-1851), the son of the great geologist John Farey Snr (1766-1826), was one of the leading experts on the steam engine of his day. His two part Treatise on the Steam Engine, published in 1827, has been lauded as the finest work on technology stemming from the Industrial Revolution: see AP Woolrich, 'Farey, John (1791 - 1851)' Oxford Dictionary of National Biography (3 January 2008) < https://doi.org/10.1093/ref:odnb/9155> accessed 4 July 2019. The engineering press was replete with articles and letters on the issue including suggested solutions in terms of the positioning of the mesh and the size of the holes. See, for example, letter by WS Grey to the Mechanics Magazine on a design for a locomotive engine spark arrester: Mechanics Magazine 705 (11 Feb, 1837) 375.

${ }^{141}$ Select Committee on Locomotive Engines Used in Narrow Streets (n 20) and text to n 20.
} 
It will also be recalled that Piggot established a presumption of fault — on the part of the railway companies - where there was clear evidence that fire damage had been caused by sparks or cinders from locomotives. Arguably, the judgment in Vaughan v Taff Vale Rly, ${ }^{142}$ which placed more emphasis on statutory authority than Piggot, signalled a retreat from any presumption of fault. Whereas in Piggot a causal connection between the spark and the fire was deemed sufficient to raise a presumption of negligence, in Vaughan it was the held that 'the mere use of fire in such engines does not make them liable for injury resulting from such use without any negligence on their part'. ${ }^{143}$

\section{A. Spark arrestors and the duty of care}

The retreat from res ipsa loquitur resulted in a greater focus upon whether the railway companies had taken reasonable steps to reduce the risk of fires. This strengthened arguments to the effect that spark arrestors imposed an unreasonable burden on the railway company in that they impaired the performance of locomotives and increased fuel costs. Moreover, it was argued that sparks could be mitigated by other measures less disruptive to the functioning of the engine. However, some juries were more receptive to these arguments than others, which meant that the outcome of a case was far from predictable.

In Fremantle $v$ London and North Western Railway, ${ }^{144}$ one of the first major reported cases to be decided after Vaughan, damages were sought in respect of the destruction of corn stacks and farm buildings. It seems that the locomotive had not been fitted with spark arrestors. There is archival evidence to suggest that the Vaughan decision, which firmly established statutory authority as a defence to fire damage caused by sparks, may have emboldened the company to fight the claim as opposed to endeavouring to reach a settlement. ${ }^{145}$ Nevertheless, the company would still have to convince the jury that it was not at fault in failing to fit spark arrestors to the locomotive in question.

The defendant produced a string of expert witnesses, including many of the most eminent locomotive engineers of the day, all of whom attested to the fact that spark arrestors were already outmoded in that developments in locomotive engineering had rendered such devices unnecessary. It was acknowledged that they were still in common usage in the United States, but this was only because there was heavy reliance on wood as a source of fuel, which is highly productive of sparks. ${ }^{146}$

In his summing up the trial judge, Williams $\mathbf{J}^{147}$, acknowledged that, following Vaughan, it was clear that the railway companies 'are bound to avail themselves of all the discoveries which science has put within their reach'. ${ }^{148}$ However, this obligation to adopt state of the art technology was immediately qualified by a proviso to the effect that the railway company need only adopt such measures if it was reasonable for it to do so in all the circumstances of the case. ${ }^{149}$ This would require the jury to weigh the magnitude of the fire risk against the burden placed on the railway company in a classic cost/benefit analysis:

\footnotetext{
142 Vaughan (n 114).

143 (1860) 5 Hurl \& N 679, 685; 157 ER 1351, 1354 (Cockburn CJ).

144 (1861) 10 CBNS 89, 142 ER 383.

${ }^{145}$ See Minutes of General Traffic Committee 7 June 1860 TNA RAIL 410/169; Board of Directors 9 June 1860 TNA RAIL 410/24 and Local Southern Sub-committee 13 June 1860 TNA RAIL 410/533. Legal advice was provided by the pioneering 'railway solicitor' Samuel Carter, who acted for both the London \& North Western Railway and Midland Railway.

146 (1861) 10 CBNS 89, 90-91; 142 ER 383, 383-84.

147 The trial was conducted at the Buckingham Spring Assizes, and there were separate claims brought by Sir Thomas Fremantle, Bart, who had a reversionary interest in the property, and the farmer in occupation, Bliss: Fremantle, Bart v London and North Western Railway Company (1860) 2 F \& F 337, 175 ER 1086; Bliss v London and North Western Railway Company (1860) 2 F \& F 341, 175 ER 1088.The cases were joined for the purposes of the action in the Court of Common Pleas, and the relevant jury directions are set out in the report of those proceedings.

148 (1861) 10 CBNS 89, 92; 142 ER 383, 384.

149 ibid.
} 
For example, if the danger to be avoided were insignificant or very unlikely to occur, and the remedy suggested were very costly or very troublesome, or such as interfered materially with the efficient working of the engine, then you will have to say whether it could reasonably be expected that the company should adopt such a remedy for such an evil. On the other hand, if the risk were considerable, and if the expense or trouble or inconvenience of providing the remedy is not great in proportion to the risk, then you would have to say whether the company could reasonably be excused from availing themselves of such a remedy because it might to some extent be attended with costs or other disadvantage to themselves. ${ }^{150}$

The jury found in favour of the plaintiff, and the defendant sought to have the verdict set aside on the ground of misdirection. In short, it was argued that the jury should not have been asked to consider whether, in order to discharge the duty of care, the railway company ought to have adopted some device which transcended 'the best in known practical use at the time'-effectively imposing an impossible burden. However, the Court of Common Pleas held that the directions did no such thing. The fact that, notwithstanding the evidence adduced as to the perfection of the engine, a fire had been caused entitled the jury to consider whether 'the engine was so constructed as to be dangerous, without a precaution of some kind'. Moreover, they were entitled to 'consider whether each set of witnesses might not have been mistaken in the degree of excellence or of defect imputed to the engine'. These were proper questions for the jury to determine and the verdict was allowed to stand. ${ }^{151}$

Fremantle was followed in Dimmock v North Staffordshire Railway $\mathrm{Co}^{152}$ in which damages were sought by a timber merchant. Witnesses claimed that sparks 'as large as walnuts' had been observed to fly out of locomotive funnels in the direction of the claimant's property on a number of occasions. ${ }^{153}$ In his directions to the jury, Keating $\mathrm{J}$ drew their attention to the balance of convenience test set out in Fremantle. ${ }^{154}$ On this basis the jury rejected the argument that the defendant was at fault in failing to fit 'wire bonnets' over the funnels of locomotives or burn coke, which is less productive of sparks. ${ }^{155}$ They were persuaded by expert arguments to the effect that both methods impaired the performance of locomotives to an unacceptable extent. The judge also suggested that there may have been fault on the part of the plaintiff in that the timber was stored in wooden sheds with tarpaulin rooves. Given that there was no conception of apportionment of liability at the time, any evidence of contributory negligence on the part of the plaintiff, deemed to be of causative significance, could prove fatal to a claim. ${ }^{156}$ The jury found in favour of the plaintiff on this point, although it was to no avail given that the railway company was found not to have been negligent in failing to fit spark arrestors or use coke in place of coal. ${ }^{157}$

The Fremantle 'balance of convenience' approach was also applied north of the border. In Murdoch $v$ Glasgow and South Western Railway ${ }^{158}$ a builder sought damages in respect of severe fire damage to his premises. The jury found in favour of the pursuer and damages of $£ 735$ were awarded. In the Court of Session Lord Neaves stated that Scottish law followed the approach laid down in the English cases. Thus a railway company would be exonerated if it could show that it had taken 'every precaution which science can suggest'. ${ }^{159}$ Nevertheless, measures which fell short of the state of the art would not lead to an automatic conclusion that the defendant had been at fault. It would be for the jury to determine "whether the company did take all reasonable precautions which they might have

\footnotetext{
150 (1861) 10 CBNS 89, 92-93; 142 ER 383, 384-85.

151 (1861) 10 CBNS 89, 98; 142 ER 383, 387.

152 (1866) 4 F \& F 1058, 176 ER 907.

153 (1866) 4 F \& F 1058, 1060; 176 ER 907, 908.

154 (1866) 4 F \& F 1058, 1063; 176 ER 907, 909.

155 (1866) 4 F \& F 1058, 1065; 176 ER 907, 910.

${ }^{156}$ See Butterfield v Forrester (1809) 11 East 60, 103 ER 926; applied in a railway context in several cases, including, for example, Martin v Great Northern Railway Company (1855) 16 CB 179, 139 ER 724, concerning a passenger injured whilst running to catch a train.

${ }^{157}$ Dimmock (n 152).

158 (1870) 8 Macph 768.

159 ibid.
} 
done' ${ }^{160}$ Lord Neaves could see no grounds for setting aside the verdict, although he acknowledged that 'we might ourselves have come to a different conclusion upon the evidence ...'. ${ }^{161}$

\section{B. Spark arresting techniques and devices featured in litigation}

As the century progressed the courts found themselves having to consider the merits of a range of devices with a view to determining whether they were necessary and sufficient to discharge the duty of care.

\section{The brick arch and deflector plate}

Notwithstanding the occasional defeat in the courts, the railway companies continued to contest the need for spark arrestors and adduced a range of arguments focusing on the technical feasibility and cost of such devices. Moreover, engineering innovations, which were principally concerned with increasing efficiency and lowering fuel costs, were presented as evidence that the railway company was doing all in its power to reduce sparks. They were able to make this argument because some reduction in sparks appears to have been a collateral benefit of certain devices or techniques. A clear example is provided by the unreported case of Davies $v$ London and North Western Rly Co. The case stemmed from an incident in which the North bound Windermere express set fire to an area of heathland at Snape farm near Whitmore Station. The fire sank down into the peaty soil and spread rapidly 'as through a grove of lucifer matches' destroying hay ricks and farm buildings in its wake.

The railway company argued that its engines were of the finest design in that they employed brick arches in the fire boxes. ${ }^{162}$ This device, comprising a structure made out of fire bricks and a deflector plate, manipulated the flow of gases in the fire box so as to reduce the number of unburnt particles drawn down the fire tubes. ${ }^{163}$ One benefit of the brick arch was that it reduced the quantity of sparks emitted; however, the technology was not developed with this problem in mind. Rather, it was introduced in response to a switch from coke to coal as the main type of fuel. Coal did not burn well in the unmodified fireboxes, and the brick arch was designed to facilitate more efficient combustion ${ }^{164}$ and thus reduce fuel costs. ${ }^{165}$ The plaintiff acknowledged the benefits of the technology but argued that there was no reason why it could not be used in conjunction with spark arrestors.

The jury initially found in favour of the plaintiff, but the decision was set aside by the Court of Queen's Bench on the grounds that it was 'against the evidence' and a retrial was ordered. ${ }^{166}$ At the retrial ${ }^{167}$ the technical arguments were repeated, and on this occasion, the judge, Mellor J, expressly directed the jury to weigh the benefits arising from the fitting of additional spark arresting devices against the costs in terms of any adverse impact on the performance of locomotives:

\footnotetext{
160 ibid.

161 ibid 769.

${ }^{162}$ For a newspaper account of the first trial at the Staffordshire Lent Assizes, see Birmingham Daily Post (17 March 1870) 6; (18 March 1870) 4.

${ }^{163}$ An invention of Charles Markham, under the auspices of Matthew Kirtley, of the Midland Railway which remained a standard feature of steam locomotive design. See Colin A Russell and John Hudson, Early Railway Chemistry and its Legacy (Royal Society of Chemistry 2012) 60.

164 ibid.

${ }^{165}$ In 1860 Markham presented a paper on the innovation to the Institution of Mechanical Engineers, which was later published: Charles Markham, 'On the burning of coal instead of coke in locomotive engines' (1860) 11 Proceedings of the Institution of Mechanical Engineers 147. Markham estimated that the device had saved the Midland Railway $£ 50,000$ due to the better fuel economy brought about by the more efficient combustion process.

${ }^{166}$ For a brief account of proceedings in the Court of Queen's Bench, see Birmingham Daily Post (21 June 1870) 8.

${ }^{167}$ For an account of the second trial, see Birmingham Daily Post (27 July 1870) 7.
} 
[F]or railway companies had to consider not only the safety of property by the side of their lines, but the speed of the trains and the convenience of the public, and it was important that they should have engines in which combustion was speedy and perfect. ${ }^{168}$

The jury clearly found this question difficult and was eventually discharged having failed to reach a verdict. It seems that the plaintiff did not pursue the matter after this setback, which is hardly surprising given that there had already been two complex and no doubt costly trials.

The adequacy of the brick arch and deflector plate as a means of reducing sparks was litigated again a few years later in Sexton v Eastern Counties Rly Co concerning the burning of a field of barley at Wherstead near Ipswich. The case was tried at the Suffolk Lent Assizes before Brett LJ. ${ }^{169}$ In this case the locomotive had been fitted with a spark arrestor, but the claimant's expert witnesses, Messrs Biddell and Turner, claimed that it had been 'put in clumsily and knocked about with a hammer'. ${ }^{170}$ They described how they had been able to shake hands with one another through one of the gaps and that a Kentish cob could pass through others. The defendant firstly endeavoured to undermine the credibility of the expert witnesses. To this end they drew attention to the fact that the witnesses were in the business of designing and building small, portable traction engines for use in agriculture. It was argued that this knowledge did not necessarily equip them to understand the different demands placed on large locomotives required to haul heavy loads.

Secondly, the defendant emphasised the fact that the locomotive ${ }^{171}$ had been fitted with a brick arch and deflector plate (or scoop as it was referred to on this occasion), which rendered the device superfluous to requirements. (Even after proclaiming the spark arrestor redundant, they would not concede the fact that it was in fact defective.) James Edward McConnell, an eminent locomotive engineer, stated that he had experimented with spark arrestors whilst engaged as locomotive superintendent for both the Midland and London and North Western railway companies. He declared that he had found 'them worse than useless, because they seriously impaired the efficient draft in the chimney, ${ }^{172}$ which disrupted the fire and caused more sparks. In his view skilful firing in combination with the brick arch and deflector plate (or scoop) was far more effective in reducing the quantity of sparks emitted. He asserted that neither the Great Northern nor the London and North Western railway companies used the equipment. In the course of cross-examination, plaintiff's counsel referred to the fact that McConnell had 'got into mischief' whilst employed by the London North Western Rly Co and that the company had had to pay for fires. ${ }^{173}$ 'They had', the witness conceded, 'but I don't say it was because they had no arrestors'. ${ }^{174}$ At this point the judge interjected with a comment which is reported as having been met with laughter: 'Of course you think the juries were wrong in those cases?' The witness agreed that he did think those juries had been wrong. ${ }^{175}$

In his summing up the Brett LJ stated that it was necessary for the jury to consider 'whether they thought the spark arrestor was a remedy and ought to be applied and if it ought to be applied it ought to be as efficient as it could reasonably be made'. ${ }^{176}$ If they thought that the spark arrestor which had been applied to the locomotive in question was not a 'reasonable one', ${ }^{177}$ they must find for the defendant. After a very short deliberation the jury found in favour of the plaintiff and awarded damages of $£ 200$. From the defendant's perspective it might have been better if a spark arrestor had

\footnotetext{
168 ibid.

${ }^{169}$ For an account of the case, see Essex Standard (Colchester, 23 March 1877) 3.

170 ibid.

${ }^{171}$ Identified as number 298 built by Kitson \& Co.

${ }^{172}$ Essex Standard (n 169).

173 ibid. This was possibly a reference to the Fremantle case (n 144), which occurred towards the end of his tenure as Locomotive Superintendent at the London and North Western Railway's Southern Division works at Wolverton. See John Marshall, A Biographical Dictionary of Railway Engineers (David \& Charles 1978) 146.

${ }^{174}$ Essex Standard (n 169).

175 ibid.

176 ibid.

177 ibid.
} 
not been fitted at all. The fact that a device had been fitted created the impression that it was deemed necessary, and a failure to fit it properly or maintain it was redolent of a lack of care. In Heathcote $v$ London and South Western Rly Co ${ }^{178}$ concerning damage to a planation caused by a spark from a locomotive appropriately named Wildfire, the jury had no hesitation in finding the defendant liable. A spark arrestor had been fitted but poorly repaired, although there was also evidence of excessive lineside vegetation. In Turner $v$ London and North Western Rly $\mathrm{Co}^{179}$ the plaintiff claimed that the bolts on a spark arresting device on the offending locomotive showed evidence of 'new working' in that the edges were sharpened. The clear implication was that the defendant had repaired the device shortly before it was examined by the plaintiff's experts. The judge warned the jury that this was tantamount to an accusation of tampering with the evidence and instructed them to think very carefully before accepting such a claim. The jury was clearly not persuaded that a railway company would stoop to such tactics and swiftly dismissed the claim.

By the close of the 1880s, there was still a high degree of uncertainty regarding whether the brick arch and deflector plate would suffice to discharge the duty of care. Nevertheless, the railway companies continued to resist any suggestion that the fitting of spark arrestors should be a legal requirement. Before long there was further litigation on the issue, and on this occasion, the defendant crushed the claim with a formidable array of arguments. In Groom v Great Western Rly Co $o^{180}$ damages of $£ 1,164$ were claimed in respect of the destruction of stacks of crops on the plaintiff's farm near Craven Arms, Shropshire. The defendant admitted that the fire had been caused by sparks from one of its passing locomotive, identified as number 815. The stacks were stored in a Dutch barn situated 30 yards from the railway. The plaintiff had had to pay an additional insurance premium to store crops within 100 yards of the railway and had successfully claimed on the policy. Thus, the present case was actually brought by the insurance company standing in the shoes of the plaintiff under subrogation rights. ${ }^{181}$

The defendant claimed that all reasonable steps had been taken to mitigate the risk of sparks in terms of the design and operation of the locomotive. A secondary argument was that the plaintiff had been guilty of contributory negligence by storing crops too close to the railway.

As regards the design and operation of the engine, the locomotive in question had a brick arch and deflector plate but had not been fitted with any form of spark arresting device. The plaintiff argued that these devices were designed to achieve more efficient combustion and had never been intended to reduce sparks. A spark arrestor was the only truly effective way of reducing sparks.

However, the plaintiff was massively outgunned in terms of the expert evidence. The plaintiff relied upon a limited number of consulting engineers with little direct experience of building and operating locomotives at the sharp end of the UK industry. These included Josiah M'Gregor, an engineer of forty-five years of experience and former superintendent of the British India Steam Navigation Company, and Druitt Halpin, a locomotive engineer who had spent most of his career working on Indian railways. The defence sought to undermine the expertise of M'Gregor on the grounds that he had never 'had charge of locomotive engines' and had never designed one. ${ }^{182}$ Halpin's expertise was challenged on the grounds that his experience almost entirely related to Indian railways, where very different conditions prevailed. As will be seen below, these attacks on the credibility of the plaintiff's witnesses proved effective and held considerable sway with the judge in his summing up. The defendant, on the other hand, produced many of the UK's leading practicing locomotive engineers of the day. These included the illustrious William Deane, the Chief Locomotive Engineer of the defendant company, Samuel W Johnston, chief locomotive superintendent of the Midland Railway, Dugald Drummond, who had served as chief locomotive engineer of the Caledonian and

\footnotetext{
${ }^{178}$ Hampshire Telegraph and Sussex Chronicle (Portsmouth, 13 July 1881) 3.

${ }^{179}$ Hampshire Advertiser County Paper (Southampton, 14 August 1886) 3.

180 (1892) 8 Times L Rep 253.

181 ibid. Unusually, this fact is expressly referred to by Mathew $\mathrm{J}$ at 255-56.

${ }^{182}$ Groom (n 180) 254.
} 
North British Railways, and George Whale, assistant locomotive superintendent of the London and North Western Railway.

The experts claimed that, although reducing sparks had not been the original purpose of the brick arch and deflector plate, this had in fact turned out to be an important corollary benefit of the technique. The familiar argument that spark arrestors would impair the draft was forcefully made.

Moreover, it was asserted that, in order to overcome the effect of the spark arrestor, the locomotive would have to be driven in a way which was likely to be more productive of sparks. The increase in sparks would thus counteract any benefit created by the arrestor. It was also argued that many companies had largely abandoned spark arrestors. For example, it was claimed that, out of 2,621 engines operated by the London and North Western Railway, only twenty-four shunting engines had spark arrestors, and this was only because those locomotives operated in docks where special regulations applied. ${ }^{183}$ Nevertheless, it was conceded that other companies, such as the Lancashire and Yorkshire Railway, made more extensive use of the devices. Overall it was estimated that sixty-six per cent of all locomotives in the country were not fitted with spark arrestors. ${ }^{184}$ Any suggestion that decisions not to fit spark arrestors were motivated by economic considerations was firmly rejected. Deane asserted that the Great Western Railway's annual locomotive budget was $£ 1.3 \mathrm{~m}$ and that fitting the devices would only increase this by $£ 300$, a sum which he described as 'trifling'. ${ }^{185}$ However, this figure only appeared to relate to the cost of supplying and fitting the devices; it did not reflect the costs of additional maintenance and increased fuel consumption arising from the impaired performance of locomotives.

Aside from technical arguments relating to the spark arresting qualities of brick arches and deflector plates, the defendants adduced statistical evidence with a view to downplaying the extent of the fire damage problem. The Attorney General, ${ }^{186}$ on behalf of the defendant, asserted that millions of miles were covered by steam locomotives each year yet only a handful of fires resulted. He claimed that there had only been eight fires in the whole of $1890 .{ }^{187}$ It was not stated how this figure was arrived at and, as will be seen, it seems very low compared to evidence later gathered by the Chambers of Agriculture. In fact, this evidence backfired on the defendants to a certain extent in that it defeated the secondary argument that the plaintiff had been guilty of contributory negligence in storing produce near the railway. Mathew $\mathbf{J}$ directed the jury that, if the risk was so low, then the plaintiff could not be criticised for exploiting the land up to the boundary with the railway. However, it supported the main argument that, when weighed against the risk, the measures adopted by the defendant appeared reasonable.

Indeed, this cost/benefit analysis was at the core of the key authority chosen by the judge in his explanation of the law to the jury, namely, Dimmock $v$ North Staffordshire Railway Co, ${ }^{188}$ which in fact merely replicated the approach set out in Fremantle $v$ London and North Western Rly Co. ${ }^{189}$ Quoting Keating J in Dimmock, Mathew J directed that ${ }^{190}$ the company was bound to "employ all due care and skill' to prevent the mischief and 'to avail themselves of all the discoveries which science has put within their reach...'. However, where the 'dangers to be avoided were insignificant' and the suggested remedies were 'costly and troublesome' or 'materially interfered with the efficient working of the engine', then the jury would have to decide whether it was reasonable for the defendant to have to adopt such measures.

Although the defendant conceded, rightly or wrongly, that spark arrestors were not costly, they made much of the fact that they were 'troublesome' and ineffective. As regards the technical evidence on this point, Mathew $\mathbf{J}$ gave a strong steer to the jury in his summing up. He referred to the fact that not

\footnotetext{
183 ibid 255.

184 ibid.

185 ibid.

${ }^{186}$ Sir Richard Webster; later ennobled as 1st Viscount Alverstone.

${ }^{187}$ Groom (n 180) 255.

${ }^{188}$ Dimmock (n 152).

${ }^{189}$ Fremantle (n 144).

${ }^{190}$ Groom (n 180) 256.
} 
one expert with current experience of designing and operating locomotives in the UK had stated that spark arrestors were necessary or effective. Moreover, they had all agreed that the construction of the engine 'was the best to prevent sparks' and that cost was not a factor in the decision not to fit spark arrestors. In order to conclude that the defendants had failed to take 'fair and reasonable precautions', the jury would have to attach more weight to the expert evidence produced by the plaintiffs. In this respect the judge overtly leant more credibility to the defendant's expert witnesses:

If they [the jury] thought, upon taking proper advice and consulting the right men, among them Mr M'Gregor and Mr Halpin, in preference to those efficient, skilful, and intelligent engineers whose opinions the jury had heard, that the defendants would have said that, without a spark arrestor, the engine was defective, and if the jury thought that the defendants could have got that advice and ought to have acted upon and believed it to be sound and reasonable, then the verdict ought to go for the plaintiffs. ${ }^{191}$

The clear implication here was that the plaintiff's experts were less 'efficient, skilful, and intelligent engineers' than those adduced by the defendant and it would be nonsensical to prefer their evidence! In the light of these comments it is not surprising that the jury only took ten minutes to find in favour of the defendants.

\section{The vortex blast-pipe and 'best practicable means'}

Hitherto, it had been for the jury to determine whether the railway company had taken sufficient steps to mitigate the risk of sparks. Although, as the Groom case demonstrates, on occasion the judge could lead them by the nose to a certain conclusion. However, before the close of the nineteenth century, there was to be a judicial pronouncement on the necessity of fitting spark arrestors when a case finally made it all the way to the House of Lords. In Port-Glasgow and Newark Sailcloth and Others $v$ Caledonian Railway $\mathrm{Co}^{192}$ damages were sought in respect of fire damage to the pursuer's flax store which was situated in close proximity to the railway.

As regards the nature of the duty to mitigate sparks, Lord Herschell LC borrowed a concept which had emerged in Victorian attempts to regulate harmful activities by way of statutory intervention, namely, the 'best practicable means' test (BPM) ${ }^{193}$ This encapsulated the cost/benefit analysis which juries had been directed to undertake in cases such as Fremantle. Thus it was held that, where a railway company knows that its locomotive engines are apt to emit sparks:

They are bound to use the best practicable means, according to the then state of knowledge, to avoid the emission of sparks which may be dangerous to adjoining property; and if they, knowing that the engines are liable thus to discharge sparks, do not adopt that reasonable precaution they are guilty of negligence and cannot defend themselves by relying upon their statutory power. ${ }^{194}$

When applied to the case at hand, the House of Lords came to the view that the best practical means had been employed in the design of the engine which emitted the offending sparks. Although the locomotive in question was not fitted with spark arrestors, it was of a new type ${ }^{195}$ and was

\footnotetext{
191 ibid.

192 (1893) $20 \mathrm{R}$ (Ct of Sess) (HL) 35.

${ }^{193}$ See, for example, section 104 of the Town Improvement Clauses Act 1847 (10 \& 11 Vict c 34) establishing an early form of statutory nuisance and related enforcement powers. It also featured in the Alkali Acts, which constituted an early attempt to regulate atmospheric emissions from a highly polluting industrial process: see section 5 of the Alkali Amendment Act 1874 ( 37 \& 38 Vict c 43). It remains a feature of the contemporary statutory nuisance regime as set out under Part III of the Environmental Protection Act 1990.

${ }^{194}$ Port-Glasgow and Newark Sailcloth (n 192) 36.

195 The case report only refers to the offending locomotive as engine No 85. However, there can be no doubt that it was a Drummond Class 80 built in February 1888 at the Caledonian Railway's St Rollox Works. See Scottish Railway Archive
} 
equipped with an Adams vortex blast-pipe. However, the device had not been designed with the railway sparks problem in mind, rather, in common with the Kirtley brick arch, it was intended to improve the performance of engines, thereby reducing fuel costs. ${ }^{196}$ The vortex blast achieved this by producing a more evenly distributed or 'softer' draught through the fire tubes. Conventional blast pipes tended to result in the lower tubes becoming blocked during the course of a journey, which increased the draught through the upper tubes. This was more likely to draw embers through the fire tube and out into the open air. Thus, a reduction in the quantity of sparks produced was a collateral benefit of the technology.

At trial a number of experts, including the locomotive designer (Drummond) and the inventor of the vortex blast-pipe (Adams), claimed that the vortex blast rendered spark arresting devices superfluous in that the softer draught greatly reduced the emission of sparks. The House of Lords saw no reason to challenge these findings. This was despite the fact that the railway company admitted that it had not conducted any trials to ascertain the effect of using a vortex blast in conjunction with a spark arrestor. ${ }^{197}$ Such an experiment would have shown whether further reductions in the emission of sparks could have been attained without sacrificing the performance of the locomotive to an unacceptable extent.

The new 'best practicable means' formulation of the duty of care was almost immediately applied by the lower courts in Clive v Portpatrick and Wigtownshire Joint Committee ${ }^{198}$ concerning fire damage to the pursuer's stackyard caused by sparks from a goods train. The Sherriff-Principal upheld the decision of the Sheriff-Substitute to the effect that, according to the facts of the case, the failure to fit a spark arrestor constituted a failure to adopt the best practicable means (BPM) of reducing the fire risk. The Port-Glasgow and Newark Sailcloth case was distinguished on the grounds that, in that case, it had been successfully argued that the vortex blast equipment was compliant with BPM. No such alternative devices had been fitted to the locomotive in the case at hand.

A short time later the use of the vortex blast-pipe, as the best practicable means of reducing the risk of sparks, received further endorsement by the senior courts in Earl of Shaftesbury $v$ London and South Western Railway concerning damage to a fir tree plantation. The jury found that, although the locomotive in question had been fitted with an Adams vortex blast-pipe, the fitting of a spark arrestor would have 'minimized' the danger and awarded the plaintiff $£ 400$. The Court of Appeal ${ }^{199}$ upheld the judgment of Lord Russell CJ in the Queen's Bench Division ${ }^{200}$ to the effect that taking reasonable care did not necessarily entail doing all in one's power. Thus, the fact that further reductions in the emission of sparks could have been secured by means of combining the vortex blast system with spark arrestors was not sufficient evidence of breach of duty:

The jury must, therefore, be taken to have found that it would have been better, or, he might say, more right, to have used the grid. That finding, however, did not prove negligence. The jury merely found that the best thing was not done. It was thereupon agreed that the Lord Chief Justice should have power to draw inferences from the facts proved, and see whether there was any negligence on the part of the defendants. ${ }^{201}$

On this basis the Lord Chief Justice had been correct to reverse the decision of the jury.

The 'vortex blast cases' illustrate the evidential difficulties which faced litigants. In both cases the courts emphasised the fact that the onus lay on the plaintiffs to prove negligence on the part of the railway companies. However, they could not prove that the vortex blast system could be used in

<http://www.govan.plus.com/beta/Shelves/M/Motive\%20Power/ByRailwayCo/caledonian/CalDrummond/CalD rummondClass80.htm> accessed 3 May 2017.

196 See WF McDermid, 'The Locomotive Blast-Pipe and Chimney (Part 1)' (1932) 22 (108) Journal of the Institute of Mechanical Engineers 397.

197 Port-Glasgow and Newark Sailcloth (n 192) 39 (Lord Herschell).

198 (1893) 1 SLT 79.

199 (1895) 11 TLR 269.

200 (1895) 11 TLR 126.

${ }^{201}$ Shaftesbury (CA) (n 199) 270. 
combination with spark arrestors, without unduly impairing the performance of locomotives, because the railway companies had not conducted trials. The railway companies were not required to conduct such trials because it was not incumbent on them to prove that the devices could be successfully used in combination. Plaintiffs simply did not have access to the expertise or resources necessary to conduct such experiments themselves.

Despite the major victory secured by the railway companies in the vortex blast cases, there was to be a final round of litigation at the turn of the nineteenth and twentieth centuries which again focused on engineering solutions to the railway sparks problem.

\section{The extended smokebox}

In Twinch v Great Western Railway Company ${ }^{202}$ damages were sought in respect of the laying waste of some six acres of oats by fire caused by sparks emitted from the leading locomotive of a 'doubleheaded' train. ${ }^{203}$ The fact that the sparks were only seen by witnesses to have issued from the lead locomotive proved fortuitous from the plaintiff's perspective. It transpired that the second locomotive, from which no sparks were seen to fly, had been fitted with an extended smokebox. ${ }^{204}$ Extended smokeboxes contained appliances designed to improve the draft through the fire tubes and reduce turbulence in the compartment. A number of the devices incorporated a mesh screen which operated as a spark arrestor. ${ }^{205}$ The fact that sparks were only seen to come from one of the locomotives appeared to provide a live demonstration of the benefits of the extended smokebox. It emerged that the GWR had been experimenting with the devices for six years and had fitted them to ten per cent of its fleet.

The plaintiffs argued that this was clearly the most effective available technology, and that the GWR had been negligent in failing to fit it to all locomotives. The main expert witness for the plaintiff, Percy Newton, stated that such devices were in widespread use in the US and Canada and had proved effective. The defendants adduced a string of expert witnesses, including once again the illustrious Dugald Drummond, ${ }^{206}$ who each attested to the fact that the offending locomotive was equipped with a brick arch and a deflector plate, which more than sufficed to discharge the duty of care.

In his summing up the judge, Day $\mathbf{J}$, gave a strong steer to the jury, and it is clear that he was utterly convinced by the arguments adduced by the plaintiff as to the necessity of fitting extended smokeboxes. He was particularly impressed by the fact that the system had been used with success in the US and France and admonished the GWR for not having rolled out the technology at a faster rate.

\footnotetext{
202 Reading Mercury (16 June 1900) 7.

203 This is only identified in the case report as engine number 3058; however, from this it is possible to ascertain that the locomotive was a GWR Class 3031, alternatively known as a Dean Single or Archilles Class, and bore the name Grierson (after a former chief engineer of the GWR). The locomotive was relatively new at the time of the incident, having been built in April 1895 at the GWR Swindon works. See JH Russell, A Pictorial Record of Great Western Engines: Volume 1 - Gooch, Armstrong and Dean Locomotives (OPC 1986).

204 This was identified as engine number 3009, another GWR Class 3031 which bore the name Flying

Dutchman, after the famous racehorse. The locomotive had originally been built according to a slightly different specification in March 1892 at the Swindon works but was rebuilt in November 1894 according to the modified specification; see Russell (n 203). It is conceivable that the re-build may have afforded the opportunity to experiment with an extended smokebox. A 1/12 scale model of the Flying Dutchman can be seen at the National Railway Museum, York: NRM exhibit 1987-8707.

${ }^{205}$ The press reports of the case suggest that the extended smokebox fitted to the second locomotive, 3009, did not have a mesh or grid contained within it. In giving evidence the Chief Assistant Running Superintendent of the GWR, Mr Waister, said that he had never seen mesh netting tried: see Reading Mercury (n 202).

${ }^{206}$ As noted above, Drummond had given evidence in Port Glasgow and Newark Sailcloth v Caledonian Railway (n 192) in his capacity as Locomotive Superintendent of the Caledonian Railway and designer of the locomotive at the centre of the case. By the time of the Twinch case, he had moved south and was Locomotive Superintendent of the London and South Western Railway: See JE Chacksfield, The Drummond Brothers: a Scottish Duo (Oakwood P 2005).
} 
He attached the "utmost importance'207 to the use of the device in other countries in that railway companies were typically subject to strict liability in those jurisdictions. ${ }^{208}$ Thus, they were motivated to find technological solutions in order to 'protect their own pockets', ${ }^{209}$ a seemingly economic type cost internalisation argument. This, he said, carried more weight than the fact that the system was not in common usage in the UK. He noted that UK companies were afforded a certain protection from liability by way of their statutory powers and thus were not subject to the same legal incentive to reduce sparks. ${ }^{210}$ This amounted to an acknowledgement that the common law had failed to provide a solution to the railway fires issue and that only the imposition of strict liability could bring about a technological solution. Given the strength of these comments, it is little surprise that the jury found in favour of the plaintiff and there is no record of the decision having been appealed. However, as will be seen below, the benefits of the extended smokebox were not universally accepted, and the railway companies resisted the notion that they should be regarded as the best practicable means of arresting sparks.

In the year following the Twinch case, the merits of extended smokeboxes were again subjected to legal scrutiny in Hipkin $v$ London and South Western Railway, although on this occasion the outcome was very different. The claim arose from the destruction of nineteen acres of standing corn by sparks from a train on the Portsmouth Direct line to London Waterloo. Once again it was argued on behalf of the plaintiff that the defendant was at fault in failing to fit the locomotive in question with an extended smokebox. The case was tried at the Winchester Spring Assizes ${ }^{211}$ before Darling J, who commenced his summing up with a reference to the aforementioned balance of convenience test proposed by Williams $\mathrm{J}$ in Fremantle $v$ London and North Western Railway. ${ }^{212}$ Thus, it was incumbent on the railway company 'to avail themselves of all the discoveries which science has put within their reach' ${ }^{213}$ for the purpose of preventing sparks 'provided that they are such as under the circumstances it is reasonable to require the company to adopt' ${ }^{214}$

As in Davies $v$ London and North Western Railway, ${ }^{215}$ the jury struggled under the weight of the technical evidence. They failed to reach a verdict on whether the absence of an extended smokebox on the offending locomotive represented a failure to take all reasonable steps to abate the sparks. The jury was discharged and a retrial was held at the following summer assizes.

At both trials it is notable that the plaintiff's case was put by the same counsel who had represented Twinch, Jelf KC, who advanced the same arguments. However, at the retrial the defendants demolished those arguments in a manner which they had failed to do in Twinch. ${ }^{216}$ To some extent this was achieved by undermining the credibility of one of the main expert witnesses for the plaintiff, Sir Frederick Bramwell, who advocated the use of extended smokeboxes with grids.

Sir Frederick was a highly eminent civil and mechanical engineer and was the younger brother of the judge Sir George Bramwell, ${ }^{217}$ who, as we have seen, was a passionate advocate of imposing strict

\footnotetext{
${ }^{207}$ Reading Mercury (n 202).

${ }^{208}$ It is indeed the case that the French railway companies were subject to stricter liability than their UK counterparts. See Yvonne Salmon, 'Technological Change and the Development of Liability for Fault in France' in Miquel Martín-Casals (ed), The Development of Liability in Relation to Technological Change (CUP 2010) 89-100. The situation in France and in certain other jurisdictions is dealt with in more detail below.

${ }^{209}$ Reading Mercury (n 202).

210 ibid.

${ }^{211}$ For an account of the first trial, see Reading Mercury ( 2 March 1901) 2.

212 Fremantle (n 144).

213 See Reading Mercury (n 211).

214 ibid.

${ }^{215}$ Davies (n 162).

${ }^{216}$ For an account of the second trial, see Berkshire Chronicle (Reading, 13 July 1901) 3.

${ }^{217}$ See BP Cronin, 'Bramwell, Sir Frederick Joseph, baronet (1818-1903)' Oxford Dictionary of National

Biography (23 September 2004) <https://doi.org/10.1093/ref:odnb/32040> accessed 8 July 2019. Sir Frederick was steeped in railway history and had designed a locomotive for the Stockton and Darlington Railway. He
} 
liability on the railway companies. Sir Frederick formed one of the first engineering consultancy businesses and combined the family's engineering and legal interests by acting as an expert witness in many cases. This made him the subject of some raillery from his elder brother who once commented that there were four categories of liars, namely, 'liars, damned liars, expert witnesses, and "my brother Fred". ${ }^{218}$ Given his younger brother's faith in technical solutions to the sparks problem, one can speculate that they may have discussed the issue on occasion. It may even have emboldened him to adopt his hard-line approach against the railway companies and made him sceptical of arguments that the industry was doing all that it reasonably could to tackle the problem.

Nevertheless, on cross-examination Sir Frederick was forced to concede that he had not been directly involved in the design of locomotives since 1865. It was pointed out that in the intervening years the commercial pressure to build ever faster and more powerful locomotives had increased exponentially, thus creating new challenges for locomotive designers. In this way the defence was able to cast doubt on the contemporary relevance of his knowledge. Thus, despite his great reputation and the esteem in which he was held by his peers, Sir Frederick was effectively dismissed as an 'armchair expert'.

Once again Dugald Drummond appeared as a key witness for the defendant. On this occasion he had a direct interest in the matter as Locomotive Superintendent for the defendant. It will be recalled that he had occupied a similar position at the Caledonian railway at the time of the Port-Glasgow and Newark Sailcloth case and had also given evidence on that occasion. ${ }^{219}$ As in Twinch he asserted that the brick arch and deflector plate were the best practicable means of reducing sparks and also drew attention to the design of the blast pipe, which was one of his own innovations. There was also a concerted effort to counter the arguments made in Twinch regarding the significance of the fact that extended smokeboxes had been used extensively in other countries. It will be recalled that such arguments had impressed Day J in Twinch. Drummond and other expert witnesses emphasised differences in working practices, the length and weight of trains, the steepness of gradients, types of fuel and so forth in order to make the case that direct comparisons were misplaced.

Whereas Day $\mathbf{J}$ had given a strong steer to the jury in favour of the plaintiff's case in Twinch, the exact opposite occurred in Hipkin. Darling J went so far as to suggest that, given that the railways were guided by statutory powers, one could presume that they were conducted in as careful a manner as possible and the best kind of engines were in use. These were certainly very bold presumptions to make given that the statutes under which the railway companies operated had nothing to say on the railway sparks issue. Nevertheless, the jury was persuaded that the locomotive must have been of the best design and returned a verdict in favour of the defendant.

The Hipkin decision was widely reported in the agricultural press and was regarded as a significant victory for the railway industry. As 'Rusticus' put it:

The great case of Hipkin $v$ the London and South Western Railway Company has produced the authoritative decision that so long as the railway companies make use of the best-known appliances for preventing the escape of sparks from the chimney they cannot be held responsible for the fire caused in this way. A man therefore who fights a big railway company on this question may make up his mind that he has an uphill task before him, and, unfortunately, farmers have not too much spare cash to waste on litigation that will certainly prove costly and most probably yield no satisfactory result. ${ }^{220}$

served as President of the Institute of Mechanical Engineers from 1874 and gained numerous awards and accolades.

${ }^{218}$ Alan A Campbell Swinton, 'Personal Recollections of Some Notable Scientific Men' (1924) 72 Journal of the Royal Society of Arts 571, 574.

${ }^{219}$ Port Glasgow and Newark Sailcloth v Caledonian Railway (n 192).

${ }^{220}$ See 'Agricultural Notes and News' The Wellington Journal (7 December 1901) 3. 
Rusticus proceeded to draw some comfort from the fact that the railway companies appeared not to be treating the decision as a reason to call off the search for technological solutions to the railway sparks problem. He noted that Dugald Drummond, the chief mechanical engineer of the defendant company in Hipkin, had developed a device which was being trialled by the London and South Western Railway Co on locomotives on the London to Salisbury route. As we have seen, Drummond had given evidence in a number of railway sparks cases, and it seems that this may well have prompted him to look for his own solution to the problem. Rusticus referred to an article published in the Times by a correspondent who had ridden on the footplate of such a locomotive and reported that 'no sign of sparking was apparent', even on the sharp gradient out of Salisbury. ${ }^{221}$ Moreover, it was asserted that the performance of the engine was not impaired and that it had handled a train of 300 tons with ease.

By this time it was also becoming clear that the UK rail industry was somewhat out of step with its counterparts in other countries on the spark arrestor issue. As we have seen, on several occasions in the UK case law, plaintiff's alluded to the fact that successful spark arresting techniques had been adopted in other countries. Whilst a detailed comparative study of the railway sparks issue in different jurisdictions is beyond the scope of this article, it is worth noting that the position adopted by the UK courts was not universal.

\section{Legal requirement to fit spark arrestors in other jurisdictions}

\section{Australia}

As a common law jurisdiction, for example, the Australian Courts felt bound to adhere to the principle established in Vaughan $v$ Taff Vale Rly $\mathrm{Co}^{222}$ to the effect that the railway operators would enjoy some statutory protection in respect of harm which could not be avoided through the use of reasonable measures. ${ }^{223}$ However, the manner in which this principle was interpreted and applied in practice differed somewhat from the UK. The arid and tinderbox nature of much of the landscape and the rapidity with which bush fires could spread over vast distances entirely altered the balance of the cost/benefit analysis in terms of deciding what were reasonable steps. This is clearly demonstrated by the case of Dennis $v$ Victorian Railway Commissioners ${ }^{224}$ where the fire rapidly spread out of control and became a major disaster causing loss of life. ${ }^{225}$ Thus, in this case it was asserted that there was a greater duty to keep the lineside clear of excessive vegetation than in the UK where different climatic conditions prevailed. ${ }^{226}$ Whereas in the UK the fitting of spark arrestors was largely regarded as a

${ }^{221}$ See 'Fire-throwing by Locomotives' The Times (London, 30 November 1901) 4. The article described the device as a chamber or casing which enclosed the bottom of the exhaust pipe within the smokebox which used an 'ingenious system of baffling the draught, in which advantage is taken of the difference in specific gravity between the gaseous products of combustion and the unconsumed particles of ash [being the red hot cinders which are typically what the term 'sparks' describes]'. The unconsumed particles would thus fall to the bottom of the smokebox. Drummond locomotives, to which spark arrestors had been fitted, were readily identifiable in that they had distinctive conical shaped smokebox doors designed to accommodate the additional equipment: see Chacksfield (n 206) app 5.

${ }^{222}$ Vaughan (n 114).

${ }^{223}$ See Topham v Christie (1879) 5 VLR (L) 306.

224 (1903) 28 VLR 576.

${ }^{225}$ For a more detailed account of the case and the scale of the devastation, see Mark Lunney, A History of Australian Tort Law 1901-1945: England's Obedient Servant? (CUP 2018) 157-60.

${ }^{226}$ The need to clear the lineside of combustible materials had already been litigated in Ramsay (Commissioner of Railways) v Taylor (1884) 18 SALR 47 in which the English authority of Smith v London and South Western Rly Co (n 138) was successfully cited as authority for the proposition that it was incumbent on the railway operator to keep the track and lineside clear of vegetation. However, in Dennis the defendant sought to distinguish Smith on the grounds that the present case was one of pure omission. It will be recalled that in the Smith case piles of 'rummage', gathered by the defendant's permanent way gang, had been left by the lineside for some considerable time in blazing sunshine; thus, the collection of combustible materials had been a positive act. In Dennis the dry grass had simply been left in its natural state. The Supreme Court was of the view that a 
'gold plated' solution, in Australia they came to be regarded as minimum requirements. This is clear from the judgment of Williams $\mathrm{J}$ in the Dennis case:

[T] he defendant knew that those engines, no matter how well constructed or what precautions might be used as to spark arrestors, will emit sparks, and it knew that at certain times of the year, especially in this country, the probable consequence of the escape of those sparks from the engines will be to set fire to the dry grass on the railway lands. ${ }^{227}$

Thus, the fact that a locomotive had been well constructed making use of available technology and properly maintained would not of itself be sufficient. ${ }^{228}$

Moreover, the railway operators did not contest the need to fit spark arrestors to anything like the extent of their UK counterparts, and the case law tended to focus on the adequacy of the devices which had been fitted - rather than whether they should have been fitted at all. In fact, juries sometimes sought to impose de facto absolute liability by rejecting judges' directions to the effect that a spark arrestor of the best design had been fitted and it was impossible to prevent all sparks. Matters came to a head in McKinnon $v$ Commissioner for Railways ${ }^{229}$ where the Supreme Court of New South Wales set the jury verdict aside on the grounds that there was incontrovertible evidence to the effect that the device used was 'the best known to science'. Nevertheless, in Cook v Commissioner of Railways Windeyer J emphasised that it was incumbent on the railway operator to keep abreast of the latest technological innovations. ${ }^{230}$

As will be seen below, the position in the UK did not alter significantly until the demise of steam in the 1960s. In Australia, on the other hand, the courts seldom wavered from the insistence on the use of spark arrestors as a minimum requirement for discharging the duty of care. In one of the last Australian railway sparks cases, Australian Railway Commissioner v Riggs, ${ }^{231}$ the 'best practicable means' (BPM) test, first applied by the House of Lords in Port Glasgow and Newark Sailcloth, ${ }^{232}$ was used to consider the adequacy of the spark arrestor design. It will be recalled that in the Port Glasgow and Newark Sailcloth case itself, BPM was used to determine whether a spark arrestor was necessary at all.

Thus, we can conclude that in Australia the fitting of a spark arrestor was the absolute minimum requirement for discharging the duty of care and was the starting point for an analysis of whether the best practicable means had been applied in the design and construction of the locomotive. This is not to say that plaintiffs had it all their own way in terms of persuading the courts as to what constituted the best practicable means of reducing sparks. In Sermon $v$ Commissioner of Railways, ${ }^{233}$ concerning a fire in Western Australia, it was argued that the commissioner had been negligent in authorising the use of local 'Collie coal' rather than the much higher-grade Newcastle coal. The former did not burn as cleanly and produced far more sparks. However, the High Court found in favour of the commissioner on the grounds that his legislative powers gave him a wide discretion as to which fuel to authorise and matters of practicability and cost had to form part of his decision. It was deemed

\footnotetext{
landowner owes a special duty to obviate hazards on his land, even where he was not responsible for bringing them onto his land in the first place: see Dennis (n 224) 579 (Williams J). This is now a well-established exception to the general proposition that one is not liable for a pure omission.

${ }^{227}$ Dennis (n 224) 579.

${ }^{228}$ The Dennis decision was endorsed a short time later in Campbell v Victorian Railway Commissioners (1907) 4 CLR 1446 where the High Court was unreceptive to arguments that it would be unduly burdensome to expect the commissioner to keep over 3,000 miles of track clear. See Lunney (n 225) 160-61.

229 (1885) 2 WN (NSW) 11.

230 (1886) 2 WN (NSW) 57.

231 (1951) 84 CLR 586.

232 Port Glasgow and Newark Sailcloth (n 134).

233 (1907) 5 CLR 239.
} 
impracticable for the railways in that part of the country to have to rely upon coal imported over vast distances at great expense. ${ }^{234}$

\section{The United States}

The English common law position was also largely adhered to in the United States where the courts settled upon a fault-based standard of liability, often citing Vaughan v Taff Vale Rly $\mathrm{Co}^{235}$ However, as in Australia, the fitting of a spark arrestor seems to have been the minimum requirement for discharging the duty of care. ${ }^{236}$ It must be noted that wood, which is highly productive of sparks, ${ }^{237}$ was more commonly used as fuel in the US with the result that spark arrestors became a standard piece of equipment early on in the development of the railroads. Moreover, as in Australia, the remote, vast and often arid nature of much of the terrain meant that fires could rapidly spread out of control and lay waste to huge tracts of land. The distinctive inverted conical funnels, often seen on locomotives in 'Western' movies, housed various types of spark arresting devices developed for wood burning locomotives. ${ }^{238}$

Of the numerous cases notable examples included Bedell $v$ The Long Island $R R C o^{239}$ concerning the destruction of a house. The fact that a spark arrestor had been removed was deemed to constitute sufficient evidence of negligence. ${ }^{240}$ Conversely, the fitting of a spark arrestor provided the railway companies with an effective defence, provided that it was of a standard design and properly maintained. In Laurel Hill Gin \& Mfg Co v Yazoo \& $M V R R^{241}$ the fitting of a spark arrestor in good order was regarded as casting doubt on whether there was a causal link between the fire and the locomotive. More usually, the fitting of such devices was simply treated as evidence that the defendant had taken all reasonable steps to prevent the harm. ${ }^{242}$ As regards the adequacy of spark arrestor designs, it was necessary to show whether the device was commensurate with the 'approved appliances in general use' standard. ${ }^{243}$ Some argued that this should be regarded as a minimum requirement and not regarded as conclusive proof of the impracticality of adhering to a higher standard. ${ }^{244}$ In Palmetto Moss Factory $v$ Texas \& $P R y^{245}$ the mere fact that sparks from a locomotive had caused a fire, notwithstanding the fact that it had been fitted with a spark arrestor, was regarded as conclusive evidence that 'it must have been faulty'. Furthermore, it must be noted that the matter was not left entirely to the common law to resolve. Certain US States intervened by way of technical regulation, thus making spark arrestors a statutory requirement. ${ }^{246}$ This is in marked contrast to the

\footnotetext{
${ }^{234}$ See Lunney (n 225) 161-65.

${ }^{235}$ Vaughan (n 114). For a contemporaneous account of how the case was interpreted and applied by the US courts, see 'Liability of Railway Company - Fire Communicated by Locomotive' (1872) 5 Alb LJ 309.

${ }^{236}$ See William C Hollier, 'Railroad Liability for Fires in Louisiana' (1954) 15 La L Rev 163.

${ }^{237}$ A phenomenon noted by Charles Dickens, no less, whilst taking a train on the Boston and Lowell line during the course of one of his famed US tours. He described '... a whirlwind of bright sparks, which showered about us like a storm of fiery snow'. Clearly, the locomotive in question was not fitted with any form of adequate spark arrestor. See Charles Dickens, American Notes for General Circulation (first published 1842, Penguin 2000) ch 4.

${ }^{238}$ John H White, A History of the American Locomotive: It's Development 1830-1880 (Dover Publications 1979) 114-23.

23944 NY 367.

${ }^{240}$ See also Davis v Natchez, Red River Texas R Gunby’s Dec 95 (La App 1885) in which a wood burning locomotive with no spark arrestor was said to have emitted 'an unusual volume of large sparks'.

${ }^{241} 149$ La 22488 So 801 (1921).

${ }^{242}$ See Hollier (n 236) 168.

243 ibid.

$244 \mathrm{ibid}$. This taps into the general argument that courts should guard against industries defining for themselves what constitutes the 'state of the art' as cost factors may be given undue weight.

245145 La 555, 564; 82 So 700, 703 (1919).

${ }^{246}$ See Hollier (n 236) 168.
} 
position in the UK where no such technical requirements were imposed by the Board of Trade, largely due to the absence of such a requirement in legislation. ${ }^{247}$.

\section{Germany}

As regards the position in continental Europe, developments in what is now Germany are of particular note in that statutory intervention occurred at a remarkably early stage in the development of the railways. ${ }^{248}$ On 29 October 1838, only four days after the opening of the first Prussian railway between Berlin and Potsdam, the Prussian Railway Act (PGE) was enacted. §25 PGE imposed strict liability on Prussian railway companies for all damage caused by the operation of the railway. It seems that the position in England, whereby the legal system allowed railway companies to cause uncompensated losses, had been noted. ${ }^{249}$ The main proponent of the legislation, von Savigny, used classic loss distribution arguments to justify the legislation. ${ }^{250}$ The railways created certain risks which could be mitigated but not entirely avoided. It would be unfair for neighbouring landowners to bear the risk of the activity.

A number of other German states followed suit with similar legislation. Even where no such legislation was forthcoming, the courts often imposed a very onerous duty of care on the railway companies which was tantamount to strict liability. Thus, the defendant would not be exonerated even where state-of-the-art spark arresting equipment had been fitted. ${ }^{251}$ Some of the reasoning applied by the courts was highly redolent of that employed by Bramwell B in the Court of Exchequer judgment in Vaughan $v$ Taff Rly $C o{ }^{252}$ It will be recalled that the judge was of the opinion that merely conducting a potentially dangerous activity is blameworthy where the risks cannot be obviated, irrespective of how many precautions are taken. This is precisely the reasoning adopted by the Oberappellationsgericht München in a case of 1861 where 'the operation of a locomotive as such was seen as necessarily constituting a culpable act! ${ }^{\prime 253}$ The upshot of these statutory and case law developments was that, although the railway companies could not escape liability through fitting spark arrestors, they could at least reduce the frequency of fires and hence their exposure to liability by adopting spark arrestors in conjunction with other preventative measures. In this respect the legal system provided an incentive to take precautions.

\section{France}

As we have seen, the legal situation in France regarding railway sparks was expressly referred to in Twinch $v G W R .{ }^{254}$ Moreover, as will be seen below, the de Glehn engines of the Chemin de fer $d u$ Nord were praised by Sydney Holland (a prominent figure in the UK rail industry) as an example of how the emission of sparks could be reduced without sacrificing performance. ${ }^{255}$ It will be recalled

\footnotetext{
${ }^{247}$ In fact, one of the only technical requirements ever imposed by the legislature on steam locomotive design was a requirement that they should 'consume their own smoke', which simply meant that they should not produce smoke; this requirement pre-dated the regulatory function of the Board of Trade in any case. Of course, steam locomotives always have produced smoke, which suggests that, despite the wording, the requirement was interpreted as an obligation to minimise smoke insofar as this was technically possible. See Colin A Russell and John A Hudson, Early Railway Chemistry and its Legacy (RSC Publishing 2012) 60.

${ }^{248}$ See Jens M Scherpe, 'Technological Change and the Development of Liability for Fault in Germany' in Miquel Martín-Casals (ed), The Development of Liability in Relation to Technological Change (CUP 2010) 14055.

249 ibid 142.

${ }^{250}$ ibid. Friedrich Carl von Savigny (1779-1861) was a German jurist and historian. He was appointed onto the commission charged with revising the Prussian code in 1820 which later led to his involvement with the Act of 1838 .

${ }^{251}$ ibid 145, citing an 1859 decision of the Oberhofgericht Mannheim: OHofG-Mannheim, Seufferts Archiv, vol 13, 329, no 235 (20 December 1859).

${ }^{252}$ Vaughan (Exchequer) (n 95).

${ }^{253}$ OAG-München, Seufferts Archiv, vol 14, 354, no 208 (16 April 1861): See Scherpe (n 248) 14.

${ }^{254}$ Twinch (n 202).

${ }^{255}$ See (n 279), below.
} 
that in Twinch the court expressly ascribed the more advanced state of spark arresting technology to the more onerous duties placed on railway companies by French law. It is indeed the case that the French companies were subject to a far stricter standard of liability than their UK counterparts, which may have led to the more rapid development of spark arresting technology. ${ }^{256}$

It is notable that the French system developed slightly later than the UK system, and there was a far greater degree of government involvement from the outset. Thus, as in Germany, there had been an opportunity to learn from the experience in the UK, and it seems that the fire risk problem was fully appreciated from the beginning. This resulted in the enactment of some preventative measures such as the banning of combustible materials, such as haystacks and thatched rooves, from being situated within twenty metres of the track ${ }^{257}$ - a measure somewhat redolent of the economic analysis of tort in that it placed some of the responsibility on the potential victims of fire damage. However, the regulation did not apply to pre-existing structures and their contents, which afforded the courts plenty of scope to impose liability on the railway companies; indeed, they set about this task with some alacrity. Early cases were brought under article 1382 of the Code civil, which imposes fault based liability. However, it was interpreted in a manner which would have met with the approval of Bramwell B in that no amount of precautions were deemed adequate to discharge the duty of care. Moreover, there was no conception of statutory authority. As the Cour d'appel of Paris put it, 'When one exercises a profession which is dangerous or inconvenient for neighbours, one should compensate for resultant damage, even if the industry is operated according to all rules of ordinary care' ${ }^{258}$

As a result the railway operators were subjected to de facto strict liability by means of an interpretation of article $382 \mathrm{C}$ civ, which rendered the mere operation of a dangerous activity a form of fault or culpable behaviour. ${ }^{259}$ This mirrored the approach adopted by Bramwell B in the Vaughan case and some of the German decisions referred to above. Moreover, it serves to shed further light on how a rule of strict liability can emerge from a rule which is ostensibly about fault, as occurred in Rylands $v$ Fletcher. ${ }^{260}$

As the century progressed case law developments enabled paragraph 1 of article $1384 \mathrm{C}$ civ, concerning strict liability for damage caused by certain objects in one's possession, to be applied to steam locomotives. ${ }^{261}$ Thus there was no longer any need to rely upon a creative interpretation of article $382 \mathrm{C}$ civ on fault-based liability. It should be noted that, unlike the position in the UK, the state was not chary about imposing technical requirements on locomotive design and measures to reduce the emission of sparks were imposed. Nevertheless, it seems that compliance with such regulations would be no defence to a claim brought under article $1384 \mathrm{C}$ civ. In a case of 1902 , concerning a forest fire caused by a spark from a locomotive, the Cour de Toulouse found in favour of the claimant notwithstanding the fact that the locomotive 'had been furnished with equipment to prevent the escape of burning coals through the chimney' and fully complied with the aforementioned regulations. ${ }^{262}$

There was clearly no means of escaping the need to fit spark arrestors, and the only way to reduce liability was to reduce the frequency of fires by continually striving to improve the technology. The success of de Glehn's express locomotives, despite the fitting of spark arrestors, may in part be due to the engineer having to work within the strictures of French law.

\section{The winning by the railway companies of the spark arrestor debate}

Notwithstanding the use of spark arrestors in other parts of the world and the continuance of experiments in the UK, it is clear that, by the onset of the twentieth century, the railway companies

\footnotetext{
${ }^{256}$ For an overview of the key legal developments in France, see Salmon (n 208).

257 ibid 93.

258 ibid 95.

259 ibid 95-97.

${ }^{260}$ See F Pollock (n 102).

${ }^{261}$ Salmon (n 208) 98-99.

262 ibid. Toulouse, 6 May 1902, S 19052 105, note Appert.
} 
had largely won the technical arguments and dispelled any notion that spark arrestors ought to be fitted as standard. A move away from res ipsa loquitur and the limited application of strict liability enabled the railway companies to frame the legal arguments in terms of technical feasibility and cost - as enshrined in the concept of Best Practicable Means (BPM). Given the expertise and resources at their disposal, the railway companies were largely able to determine for themselves what measures constituted the BPM standard in terms of reducing sparks. Attempts to challenge these standards by way of evidence from independent consulting engineers and comparisons with other rail systems were largely rebuffed. Moreover, as regards public regulation of the industry, the Board of Trade had little interest in imposing top-down controls on locomotive design. As a consequence, farmers and landowners were left in a state of extreme exasperation about the state of the law and there were increasingly vociferous demands for statutory intervention.

\section{CALLS FOR STATUTORY INTERVENTION}

At the turn of the nineteenth and twentieth centuries, the problem of fire damage caused by sparks from locomotives was an increasingly prevalent item on the agendas of agricultural societies. The strength of feeling elicited by the issue is very clearly demonstrated by the proceedings of a general meeting of the Bedfordshire Chamber of Agriculture and Farmers' Club. ${ }^{263}$ Having undertaken some considerable research into the extent of the fire damage problem in the area, the Honourable Secretary (H Trustram Eve), was able to present the meeting with a long list of examples in which serious damage had been caused by sparks from locomotives. ${ }^{264}$ A survey of farmers and landowners revealed that acres of crops, thousands of trees, hundreds of yards of hedging and numerous stacks of corn and hay had been destroyed in Bedfordshire and neighbouring counties alone. The railway companies usually ignored requests for compensation, and insurance claims were rarely successful because policies excluded fire damage to crops situated within 100 yards of the railway.

The meeting was then addressed by a Mr FW Beck, a solicitor from Luton, who presented a paper entitled 'The Law as to the Liability of Railway Companies for damage to agricultural property ${ }^{265}$ in which he sought to shed some light on the reasons for the implacable attitude of the railway companies. In short, he argued that the law had swung very firmly in their favour and they had little incentive to meet claims. He sketched out a number of the key case law developments and argued that, although the courts had initially established a very onerous duty to mitigate the risk of sparks, the duty had been constantly watered down. Thus, he argued that the Piggot ${ }^{266}$ case established 'sufficient presumptive evidence' ${ }^{267}$ that fire damage must have arisen through a want of care. He continued that the Vaughan ${ }^{268}$ and Fremantle ${ }^{269}$ cases established that this presumption of fault could be rebutted by evidence that the defendant had done all in its power to mitigate the risk. Nevertheless, the judgments put the onus firmly on the railway companies to show that they had taken 'every possible precaution' and kept pace with the latest technological developments. The Smith ${ }^{270}$ case was used as an example of the courts firmly rejecting the notion that emission of sparks alone is sufficient evidence of negligence. Mr Beck's main criticisms were reserved for the Shaftesbury ${ }^{271}$ case in which, as we have seen, it was held that something less than the most effective measures would suffice to discharge the duty and that the onus was on the plaintiff to establish fault. Mr Beck noted

\footnotetext{
${ }^{263}$ Bedfordshire Chamber of Agriculture and Farmers' Club, 'Proceedings of General Meeting, held at Bedford, October 28th, 1899, and Paper by Mr FW Beck, on "The law as to the liability of railway companies for damage to agricultural property” and discussion thereon' (Earl Grey Pamphlets Collection 1899).

264 ibid 3-4.

265 ibid 4-7.

${ }^{266}$ Piggot v Eastern Counties Railway (n 85).

267 This chimes with the foregoing case law analysis in this article in which it is argued that the decision in

Piggot was tantamount to an application of res ipsa loquitur.

${ }^{268}$ Vaughan $v$ Taff Vale Railway Company (n 114).

${ }^{269}$ Fremantle v London and North Western Railway (n 144).

${ }^{270}$ Smith v London and South Western Railway (n 138).

${ }^{271}$ Earl of Shaftesbury v London and South Western Rly Co (n 199).
} 
that, following the Shaftesbury decision, the railway companies were even less inclined to meet claims. Moreover, by allowing the railway companies to avoid having to bear the costs of fire damage, the common law had failed to provide a sufficient incentive for the development of better spark abatement technology:

These are days of prolific invention, particularly in engineering work, and if companies were held, ipso facto, liable for all damage occasioned by sparks from their engines, they would not be long in discovering a means of preventing the damage without diminishing the efficiency of their locomotives. ${ }^{272}$

According to the record of the proceedings, this comment met with loud applause. ${ }^{273} \mathrm{Mr}$ Beck concluded that the time had come for Parliament to resolve the issue by way of statutory intervention. To this end chambers of agriculture throughout the land should pass resolutions to the effect that legislation was necessary. These resolutions should then be channelled to the Central Chamber of Agriculture ${ }^{274}$ with a view to organising a deputation to the Board of Agriculture. In fact, such resolutions were passed and, as we shall see, the Central Chamber of Agriculture played a part in bringing about legislation. ${ }^{275}$

The issue of railway fires had also been taken up by the main journals and publications serving the landowning and farming classes. An article in The Field magazine, ${ }^{276}$ cited in the discussion which followed Beck's paper at the Bedfordshire Chamber of Agriculture meeting, ${ }^{277}$ argued that the immunity conferred by section 86 of the Railway Clauses Consolidation Act (1848) could only be justified on the basis that Parliament had been fully apprised of all the risks and judged that the public benefits of railways outweighed the harms. Would Parliament have been prepared to grant such a widespread immunity if it had been fully aware of the magnitude of the fire damage risk?

The grounds upon which this extraordinary licence to trespass with hot coals was statutably conferred on railway companies was that of pro bono publico.... It may be doubted whether if incendiarism of this kind had been contemplated when the Railway Clauses Consolidation Act was passed, such immunity as at present would have been conferred upon railways without the smallest provision for compensation to the occupier of the soil. ${ }^{278}$

Other critics of the approach adopted by the courts in common law actions took to the letters pages of The Times. One Sydney Holland ${ }^{279}$ wrote to The Times on three occasions and argued that

\footnotetext{
272 Proceedings of General Meeting of the Bedfordshire Chamber of Agriculture (n 263) 6.

273 ibid.

${ }^{274}$ As regards the nature of farming politics in the late nineteenth and early twentieth centuries and the role of local chambers of agriculture and the Central Chamber of Agriculture, see Nicholas Goddard, 'Agricultural Institutions: Societies, Associations and the Press' in Edward John T Collins and Joan Thirsk (eds), The Agrarian History of England and Wales (CUP 2000).

275 The country and agricultural press of the time carries various reports of proceedings in the chambers of agriculture: see, for example, The County Gentleman: Sporting Gazette, Agricultural Journal, and 'The Man about Town' (London, 9 December 1899) 1569.

276 The Field (London, 19 August 1899) 28.

277 (n 263) 7.

278 The Field (n 276).

${ }^{279}$ The Sydney Holland in question later became the 2nd Viscount Knutsford and is best known for his work in healthcare reform and hospital administration, especially as Chairman of the London Hospital. However, he also had railway interests and was a director of a number of companies, including early electric railway companies that would later form part of the London Underground system; he had shares in many others. In a letter dated 10 September, he indicated that he was not a landowner and thus had no personal interest in the issue in that respect. Moreover, given that he had railway interests, it was 'good natured' of him to argue in favour of imposing greater liability on the railway industry for such damage. He also made the curious suggestion that five per cent of any damages recovered should be paid to the London Hospital: Sydney Holland, 'Engine Spark Fires' The Times (London, 14 September 1899) 4. Although he may not have been a landowner as such at the material time, it seems that he invested large sums in purchasing grouse moors and forests after succeeding his
} 
the legal position imposed 'an intolerable hardship on farmers' ${ }^{280}$ He cast doubt on the House of Lords finding in Port-Glasgow and Newark Sailcloth Company ${ }^{281}$ that the Adams vortex blast constituted the best practicable means of reducing the emission of sparks. ${ }^{282}$ In any case, he argued, matters had moved on considerably in the six years since the decision, and it was now clear that the extended smoke box was a far more effective technological solution and had 'shown itself to be a practically perfect preventer of sparks'. ${ }^{283}$ Holland contended that the device was in widespread use in the United States and continental Europe and that there was no evidence to suggest that it had had a deleterious effect on the performance of engines. On the contrary, the summer express service in France operated by the Chemin de Fer du Nord, which used de Glehn Engines ${ }^{284}$ fitted with extended smokeboxes, was ten per cent faster than any comparable British Service. He lamented that this was yet another case in which, having pioneered a technology, Britain had surrendered its lead to foreign counterparts. ${ }^{285} \mathrm{He}$ called upon the Chambers of Agriculture to support further litigation so that the latest technological developments could be reviewed by the higher courts and the Twinch case was cited as judicial endorsement of the extended smokebox. ${ }^{286}$ Failing further successful litigation it would be incumbent on Parliament to rectify the situation by way of legislation. As we have seen, further successful litigation was not forthcoming and in Hipkin ${ }^{287}$ the notion that the extended smokebox offered a 'silver bullet' solution, which ought to be fitted as standard, was rejected.

In fact, during the course of Holland's correspondence, a private Members Bill had been introduced to Parliament by Mr Jeffreys, the Member of Parliament for Basingstoke. ${ }^{288}$ Jeffreys was a landowner ${ }^{289}$ and a prominent figure in the Central Chamber of Agriculture, ${ }^{290}$ which placed the organisation on the inside track in terms of its ability to influence the parliamentary process. Holland referred to the Bill but was pessimistic regarding its prospects for success: '[T]he Bill backed by $\mathrm{Mr}$ Jeffreys and others seems likely to share the fate of many other much needed Bills' ${ }^{291}$ As we shall see, legislation was eventually enacted but it was a lengthy process and the Act which finally emerged was a considerably diluted version of the original Bill.

\section{THE RAILWAY FIRES ACT A. The parliamentary debates}

The Bill referred to by Sydney Holland in his letter to The Times was the Compensation for Damage to Crops Bill. ${ }^{292}$ As is often the case in respect of private members Bills, the promoters struggled to secure sufficient time for parliamentary debate without governmental support, and there were four attempts to get the Bill onto the statute book between 1900 and 1905. The first Bill ${ }^{293}$ was not drawn

father as Lord Knutsford in 1914. See John Gore, revised by Patrick Wallis, 'Holland, Sydney George, second Viscount Knutsford (1855-1931)' Oxford Dictionary of National Biography (September 2004)

<https://doi.org/10.1093/ref:odnb/33943> accessed 10 July 2019.

${ }^{280}$ Sydney Holland, 'Engine Spark Fires' The Times (London, 14 September 1899) 4.

281 (n 192).

${ }^{282}$ Holland (n 280).

283 ibid.

${ }^{284}$ Alfred de Glehn was an English-born locomotive designer most celebrated for his work on the French railways. See Justin Corfield, 'De Glehn, Alfred George (1848-1936)' The Encyclopaedia of the Industrial Revolution in World History (Rowman and Littlefield 2015) 245-46.

${ }^{285}$ Holland (n 280).

286 This letter was reproduced in the Cheshire Observer: 'Damage to Crops from Engine Sparks', Cheshire

Observer (Chester, 14 July 1899).

287 (n 216).

288 Arthur Frederick Jeffreys (1848-1906).

289 Jeffreys owned a fine estate at Burkham House near Alton, Hants.

${ }^{290}$ See AHH Matthews, Fifty Years of Agricultural Politics, being the History of the Central Chamber of Agriculture (PS King \& Son 1915).

${ }^{291}$ Sydney Holland, 'Damage to Crops by Sparks from Railway Engines' The Times (London, 22 May 1900) 3.

${ }^{292}$ Compensation for Damage to Crops HC Bill (63 Vict) [51].

293 ibid. 
at the ballot ${ }^{294}$ and thus failed at the first hurdle. ${ }^{295}$ Jeffreys attempted to enlist government support for the Bill and asked the Prime Minister, Arthur Balfour, for 'facilities for discussion of the short Bill now before the House'. ${ }^{296}$ The latter declined his request but acknowledged 'that there is a curious discrepancy between the law which applies to road locomotives and that which applies to railway engines, the one being liable and the other not ${ }^{\prime}{ }^{297}$ Balfour also stated that the President of the Board of Agriculture had no detailed information on the extent of the fire damage caused to agricultural property by railway sparks. This prompted the Central Chamber of Agriculture to start garnering more detailed statistics. ${ }^{298}$ The Bill was reintroduced the following year and made more progress but was ultimately unsuccessful..$^{299}$ There is also a 1902 version of the Bill ${ }^{300}$ in the archives, but there is no record of this having made any headway. ${ }^{301}$ The Bill finally made it into law at the fourth attempt in $1905,{ }^{302}$ largely due to the government deciding to lend it a measure of support. But, as we shall see, this was at the price of watering down the Bill and making considerable concessions to the railway companies. ${ }^{303}$

The main debates took place at the second readings of the Bills introduced in $1901^{304}$ and $1905,{ }^{305}$ respectively. They were relatively short but vigorous affairs, and a number of forceful arguments were made both in favour and against the need for legislation. ${ }^{306}$ Some, but by no means all, of the MPs who took part had agricultural and railway interests. ${ }^{307}$ As regards the main arguments in favour, it was pointed out that the common law had resulted in an anomalous distinction between road-going steam locomotives and railway locomotives. ${ }^{308}$ As we have seen, only operators of the latter had escaped strict liability by dint of their privileged position under statute. The evidential difficulties of establishing negligence on the part of the railway companies, in terms of how locomotives had been constructed and operated, were emphasised. ${ }^{309}$ These difficulties are certainly borne out by the case law analysis undertaken above. On a similar theme it was argued that the courts were not best suited to determining what measures constituted the 'best practicable means' of reducing sparks. ${ }^{310}$ Only legislation which placed the costs of fire damage firmly on the shoulders of the railway companies would provide a sufficient incentive to develop technological solutions to the problem, such as spark arrestors which did not impair the performance of locomotives. ${ }^{311}$ Some MPs argued that stricter forms of liability had brought about such developments in North America without imposing unduly burdensome costs on the railway companies. ${ }^{312}$ Another popular argument was that

\footnotetext{
${ }^{294}$ In arcane and still extant procedure, ballot balls, corresponding with numbers allocated to private members Bills, are drawn from a bowl. Only the first few to be drawn will be allotted time for parliamentary debate.

295 See AHH Matthews (n 290) 233.

${ }^{296}$ HC Deb 08 May 1900, vol 82, cols 1106-07.

297 ibid.

${ }^{298}$ See AHH Matthews (n 290) 233.

${ }^{299}$ Compensation for Damage to Crops HC Bill (1 Edw 7) [12].

${ }^{300}$ Compensation for Damage to Crops HC Bill (2 Edw 7) [7].

${ }^{301}$ One can surmise that once again the Bill may have failed at the ballot stage.

302 Compensation for Damage to Crops HC Bill (5 Edw 7) [117].

${ }^{303}$ See AHH Matthews (n 290) 233-44.

3041901 Bill (n 299).

3051905 Bill (n 302).

${ }^{306}$ HC Deb 6 March 1901, vol 90, cols 737-63; HC Deb 3 March 1905, vol 142, cols 348-74.

${ }^{307}$ It is noteworthy, however, that one of the most vociferous opponents of the Bills in debate was Sir Frederick Banbury, chairman of the Great Northern Railway. As will be seen below, Banbury also featured heavily in the Committee which watered down the Bill

308 This was promoted as the main justification for the legislation on the memorandum on the face of the Bills.

${ }^{309}$ See, for example, Mr Vicary Gibbs (Hertfordshire, St Albans) and Mr Bryce (Aberdeen) 1901 debate (n 306) cols 749 and 753; and Mr Mount (Berkshire, Newbury) 1905 debate (n 306) col 351.

${ }^{310}$ In this respect there was an implied criticism of the Port-Glasgow and Newark Sailcloth case (n 134): see Mr Munro Ferguson (Leith Burghs) 1901 debate (n 306) col 742.

${ }^{311}$ See, for example, Mr Hudson (Hertfordshire, Hitchin), who in introducing the 1901 Bill made a direct link between the legislation and a requirement to fit spark arrestors: see 1901 debate (n 306) col 738.

${ }^{312}$ See, for example, Colonel Milward (Warwickshire, Stratford-upon-Avon) 1901 debate (n 306) col 751.
} 
insurance did not provide a viable alternative to compensation in that most insurance companies excluded damage caused to crops grown near the railway or imposed extortionate premiums. ${ }^{313}$ Causation difficulties were also alluded to by Jeffreys, who stated that it was very difficult to trace the specific engine which had caused the fire. Thus, successful claims usually depended upon eye witness testimony of sparks or cinders flying out of the funnels and setting fire to neighbouring property. ${ }^{314}$ Given that the Bill contained no specific provisions on alleviating causation difficulties, the relevance of this observation is not readily apparent. However, Jeffreys made the point in the context of the need to fit spark arresting devices. If locomotives were all fitted with such equipment, there would be fewer fires in the first place and fewer people would be faced with the need to overcome these evidential difficulties.

As regards those arguments ranged against the Bill, a number of MPs asserted that injurious affection, such as fire damage, had already been reflected in the compensation which the railway companies had paid to landowners across whose land the railways had been built. ${ }^{315}$ This was countered by arguments to the effect that many farmers were tenants who never benefited from such payments; moreover, such payments were made a long time ago and would not have catered for dramatic increases in rail traffic. ${ }^{316}$ Other financial arguments focused on the wider economic benefits of the industry which, it was claimed, outweighed the cost of localised harms. ${ }^{317}$ Arguments pertaining to the anomalous situation of the railway companies vis a vis the operators of road-going locomotives were rejected by the opponents of the Bill on the grounds that the latter had not had to pay for the infrastructure or compensate landowners. ${ }^{318}$ A number of participants in the debate rejected arguments to the effect that adequate insurance cover was not available and maintained that this was a viable alternative to compensation. ${ }^{319}$ The risk of fraudulent claims was raised a number of times during the debates, ${ }^{320}$ although it was pointed out that this was not peculiar to the Bill at hand; attaching undue weight to such concerns would prevent all reforms being made. ${ }^{321}$ The causation argument was rejected on the grounds that the Bill did not in fact contain any provisions designed to alleviate such evidential difficulties. ${ }^{322}$ Some MPs expressed concerns regarding the effect of the proposed legislation on footplate men and wondered whether the railway companies would seek to penalise them for fire damage as a response to being required to pay more compensation. ${ }^{323} \mathrm{On}$ a number of occasions MPs queried why farmers were being singled out for special treatment given that fire damage was caused to all types of property. How could calls for the compensation to be extended to other types of damage be logically resisted? $?^{324}$ As the above case law analysis demonstrates, damage was often caused to buildings and in fact the leading House of Lords judgment in PortGlasgow and Newark Sailcloth ${ }^{325}$ concerned industrial premises unrelated to farming. In the 1905

\footnotetext{
${ }^{313}$ See, for example, Mr Mount (Berkshire, Newbury) 1905 debate (n 306) col 350.

${ }^{314}$ See, for example, Mr Jeffreys (Hampshire, N) 1901 debate (n 306) col 739.

${ }^{315}$ See, for example, Sir Frederick Banbury (Camberwell, Peckham) 1905 debate (n 306) cols 356-57.

316 See, for example, Mr George White (Norfolk, NW) 1905 debate (n 306) col 353.

${ }^{317}$ As regards local finances, it was pointed out that in some parishes the railway companies accounted for seventy-five per cent of the rates: see, for example, Mr Stuart Wortley (Sheffield, Hallam) 1901 debate (n 306) col 746. As regards the national economy, it was claimed at one point that, to date, the railway companies had invested $£ 1.2$ billion in the system: See Sir Frederick Banbury (Camberwell, Peckham) 1905 debate (n 306) col 356.

318 See, for example, Sir Frederick Banbury (Camberwell, Peckham) 1905 debate (n 306) cols 356-57.

${ }^{319}$ See, for example, Mr Jackson (Leeds, N) 1901 debate (n 306) col 758.

${ }^{320}$ See, for example, Mr Bell (Derby) 1901 debate (n 306) col 747.

${ }^{321}$ See, for example, Mr Cripps (Lancashire, Stretford) 1905 debate (n 306) col 365.

${ }^{322}$ See, for example, Mr Bell (Derby) 1901 debate (n 306) cols 747-48.

${ }^{323}$ See, for example, Mr Bell (Derby) 1901 debate (n 306) col 748, who cited the example of smoke controls implemented by the London County Council. He claimed that enginemen had been routinely fined or suspended whenever their employers were prosecuted for the emission of excessive smoke. Thus, whilst he did not oppose the Bill, he was in favour of a specific provision requiring the fitting of spark arresters so as to ensure that enginemen had the equipment to minimise the risk of causing fires which could trigger liability underthe regime. ${ }^{324}$ See, for example, Mr George Whitely (Yorkshire, WR Pudsey) 1905 debate (n 306) col 373.

${ }^{325}$ Port-Glasgow and Newark Sailcloth (n 134).
} 
debate the Attorney General (Sir Robert Finlay) answered such concerns by claiming that crop damage was 'a very special case' and that 'a grievance undoubtedly existed' ${ }^{326}$ It should also be noted that the matter had become an agricultural issue due to the lobbying orchestrated by the Central Chamber of Agriculture. As a result, by the time the 1905 Bill was introduced, the matter had been adopted by the Board of Agriculture. In a number of the farm cases reviewed above, damage went beyond crops and destroyed farm buildings. However, if farmers were allowed to claim for this loss under the regime there would have been no grounds to resist extending coverage to all those owning property along railway lines; one cannot sensibly distinguish between farm buildings and all other types of buildings. By confining the Bill to crop damage, it was possible to argue that the loss was unique to farmers (or plantation owners where woodland etc was at issue).

It is also clear that a number of MPs struggled with the entire concept of strict liability and regarded it as unjust and draconian. ${ }^{327}$ Reversing the burden of proof on negligence was proposed as a fairer solution to the evidential difficulties facing plaintiffs. ${ }^{328}$ However, other MPs expressed reservations regarding whether the evidential difficulties faced by plaintiffs would be alleviated to any great extent and it was dismissed as 'an illusory proposal'. ${ }^{329}$ Such reservations were well founded in that, as we have seen in the foregoing analysis, some of the earlier common law cases appeared to adopt such an approach through the application of res ipsa loquitur. It will be recalled that this put the onus on the railway companies to justify the absence of spark arrestors. However, as has also been seen, it became increasingly difficult to counter technical arguments to the effect that a failure to fit spark arrestors could not of itself be regarded as prima facie evidence of a breach of the duty of care.

As noted above, in contrast to the earlier Bills, the Bill introduced in 1905 gained measured governmental support as evidenced by the contributions of the President of the Board of Agriculture (Mr Ailwyn Fellowes) ${ }^{330}$ and the Attorney General (Sir Robert Finlay). ${ }^{331}$ However, both made it clear that the Bill would be subject to intense scrutiny in committee and hinted at major modifications. The Bill passed second reading and was submitted to the Standing Committee on Trade (including Agriculture and Fishing), Shipping, and Manufactures, where major changes were indeed made. ${ }^{332}$ It is clear that the committee and been preceded by intensive lobbying from the railway industry ${ }^{333}$ and the committee instantly set about introducing a range of amendments which substantially blunted the proposed regime. The amended Bill which emerged from the process was still very short but was now approximately twice the length of its predecessors due to a range of concessions to the railway companies. Strict liability was maintained, but a cap of $£ 100$ pounds was imposed in place of unlimited liability. Furthermore, it empowered the railway companies to enter upon adjoining land without the need to gain consent and take preventative action to reduce the risk of fire spreading, such as clearing vegetation and digging trenches up to a distance of twenty yards from the track, although compensation would at least payable for such incursions. Finally, an extremely restrictive limitation period of only seven days was introduced for filing claims. The only amendment which did not adversely affect farmers and plantation owners was a clarification to the effect that, where the fire was

\footnotetext{
${ }^{326}$ See 1905 debate (n 306) col 371.

${ }^{327}$ See, for example, Sir Edward Grey (Northumberland, Berwick) 1905 debate (n 306) col 367.

${ }^{328}$ See, for example, Mr Stuart Wortley (Sheffield, Hallam) 1905 debate (n 306) col 364 and Mr Cripps

(Lancashire, Stretford) 1905 debate (n 306) col 366.

${ }^{329}$ See, for example, Sir Robert Reid (Dumfries Burghs) 1905 debate (n 306) col 372.

${ }^{330}$ See 1905 debate (n 306) cols 360-62.

${ }^{331}$ See 1905 debate (n 306) cols 371-72.

${ }^{332}$ Standing Committee on Trade (including Agriculture and Fishing), Shipping, and Manufactures, Report on the Compensation for Damage to Crops Bill (HC 1904-05, 97 - VII).

${ }^{333}$ In his historical account of the Central Chamber of Agriculture, AHH Matthews stated that 'the railway party intimated that they were willing to make a compromise' in order to drop their opposition to the Bill. It is not clear what Matthews meant by 'the railway party', although it is reasonable to assume that he was referring to certain MPs with railway interests: see Matthews (n 290) 233. It is notable that one of the most vociferous opponents of the Bill in the House of Commons debates and the committee stage was Sir Frederick Banbury, chairman of the Great Northern Railway. Indeed, during the course of the second reading debate on the 1905 Bill, Sir Frederick expressly referred to the possibility of such an arrangement: see 1905 debate (n 306) col 372.
} 
caused by a locomotive owned by a company operating on the tracks of another, both railway companies would be jointly and severally liable.

The third reading of the amended Bill took place in July $1905,{ }^{334}$ and in the preceding debate the proponents of the Bill fought a short, but mainly fruitless, rear-guard action to reverse, or at least moderate, some of these changes. Those with agricultural constituencies noted that "nearly all the alterations in Grand Committee seemed to be in favour of the railway companies'. ${ }^{335}$ The enemy of time was used to dissuade most MPs from pursuing their attempts to rebalance the Bill in favour of farmers. The cap on liability was not raised by a penny and the only slight concession was to marginally relax the limitation period. Thus, farmers would be required to notify the railway company of the fire and intention to claim within seven days but would have fourteen days in which to file the particulars of the claim. A final amendment changed the name of the Bill and it passed into law as the Railway Fires Act 1905. Thus, farmers were left with a compensation regime which was very limited in scope. Where damage was caused to a building, which was often the case, or exceeded $£ 100$, they were left to their original remedies at common law. Some relief was offered in 1923 when the cap on liability was raised to $£ 200$ and the limitation period for filing the particulars of a claim was increased to twenty-one days. ${ }^{336}$

Despite the replacement of steam by diesel and electric traction in the 1960s, the legislation has remained in force to this day due to the number of preserved steam locomotives still in use on heritage lines and the occasional mainline excursion train. Astonishingly, the cap on liability remained at $£ 200$ until 1981 whereupon it was raised to $£ 3000 .{ }^{337}$ The Secretary of State was also given the power to raise the cap by way of statutory instrument; ${ }^{338}$ however, to date this power has not been used.

\section{B. The scope of the Railway Fires Act}

Following the introduction of the Railways Fires Acts, there was some litigation on the correct interpretation of certain aspects of the regime. In Martin v the Great Eastern Railway Company, ${ }^{339}$ concerning the destruction of barley, it was held that the particulars of the claim sent to the railway company had to itemise the loss in monetary terms. Further clarifications were offered in $A G v$ Great Western Railway Company ${ }^{340}$ concerning damage to trees on land managed by the Commissioners of His Majesty's Woods and Forests (the precursor of the Forestry Commission). The case established that any claim for compensation under the Act was without prejudice to any claim in negligence for additional sums going beyond the cap on liability imposed by the legislation. Moreover, where damage costs exceeded the cap on liability (as in this case where damage amounted to £3000), claimants could seek partial recovery of the total losses under the statutory regime. Gracey $v$ Great Northern Railway (Ireland) ${ }^{341}$ illustrated a limitation of the scope of the regime. Section 4 of the 1905 Act excluded harvested crops which had been 'led or stacked'. In Gracey it was held that grass which had been cut by a 'binder' and left 'in stooks of four sheaves each' could be regarded as having been 'led or stacked' within the meaning of the Act. Finally, following post-war nationalisation, one of the last railway sparks cases reflected the changing face of British agriculture and increasing state intervention. In J Langlands (Swanley) Ltd v British Transport Commission ${ }^{342}$ a claim was brought in respect of damage to a wheat crop. It was held that, aside from the market value of the crops, the farmer could also claim for his lost 'deficiency payment' as the combined sum fell within the $£ 200$

\footnotetext{
${ }^{334}$ HC Deb 7 July 1905, vol 148, cols 1478-92.

335 ibid, Mr Soares (Devonshire, Barnstaple) cols 1482-83.

${ }^{336}$ Railway Fires Act (1905) Amendment Act 1923(13 \& 14 Geo 5 c 27), s 1.

337 Transport Act 1981, s 38(1).

338 ibid.

339 [1912] 2 KB 406.

340 [1924] 2 KB 1.

341 (1947) 85 ILT 179.

342 [1956] 1 WLR 890 (QB).
} 
cap. These were an early form of government subsidy designed to smooth out fluctuations in the market value of commodities by providing farmers with a guaranteed minimum price for their produce. $^{343}$

As will be seen in the following section, the combined effect of a limited statutory compensation scheme and the unresolved difficulties of establishing negligence for damage not covered by the regime meant there was little legal incentive to resolve the sparks issue before the demise of steam traction on British railways.

\section{RAILWAY SPARKS IN THE TWENTIETH CENTURY: UNFINISHED BUSINESS FOR THE COMMON LAW}

As we have seen, in the early 1900s, as Parliament debated the need for a compensation regime, the railway companies continued to experiment with engineering solutions to the railway sparks problem. The lack of a coherent response was largely due to the fragmented nature of the industry where many companies built their own engines or delegated the work to numerous contractors. ${ }^{344}$ The specialist engineering press returned to the issue from time to time and the merits and shortcomings of various methods continued to be debated. ${ }^{345}$ There is no evidence to suggest that the modest compensation scheme ushered in by the Railway Fires Act served as any additional incentive to resolve the issue.

Moreover, as we have seen, the limited scope of the Act meant that damage to buildings and many other types of harm fell outwith the scope of the regime. These excluded categories included personal injuries which could be caused by railway sparks, although cases of serious harm appear to have been rare. One tragic example concerns a fatal accident in which a spark set fire to the light summer clothing of a passenger who was merely standing on the platform at a station waiting for a train. ${ }^{346}$ The fact that a passenger could be killed in such a way was deeply shocking, and the coroner expressed his dismay at the fact that the railway companies seemed unable or unwilling to find a solution to the sparks problem:

The nuisance, to say the least, is a deplorable one, and one would think that the companies would in their own defence put a stop to it. It is surely not beyond the scope of scientific inventiveness to provide an adequate preventive and remedy, and if such be the case, we may trust that the means will be devised, and, what is more, constantly used. The public, apart from the annoyance not uncommonly encountered on the railway from such a source, must be sadly impressed by the awful death of Mrs Neale, and we must fervently trust that the occurrence of accidents of this kind will in future be rendered wholly impossible. ${ }^{347}$

Nevertheless, these calls appear to have remained unheeded and the problem rumbled on throughout the final decades of the age of steam.

\section{A. The 'Big Four'}

As the century progressed the railway companies were subject to major restructuring and reorganisation and the exigencies of two world wars in which they were run into the ground. ${ }^{348}$ After the First World War the myriad nineteenth-century companies were regrouped into 'the Big Four', ${ }^{349}$

\footnotetext{
343 Agricultural Act 1947, s 4.

${ }^{344}$ At the time of nationalisation (see below), British Railways inherited some 448 different classes of steam locomotive. See Wolmar (n 48) 273.

${ }^{345}$ See, for example, James A Robertson, 'Spark Prevention Devices on Locomotives' (1926) 16(75) Journal of the Institution of Mechanical Engineers 703.

346 'Railway Sparks' Midland Daily Telegraph (Coventry, 6 September 1906) 2.

347 ibid.

${ }^{348}$ See Wolmar (n 48) 264.

${ }^{349}$ By the time of the Great War, there were 120 separate railway companies. The Railways Act 1921 grouped these into four large companies_-namely, the London Midland and Scottish Railway (LMS), the London and North Easter Railway (LNER), the Great Western Railway (GWR) and the Southern Railway (SR).
} 
and in the immediate wake of the Second World War the industry was nationalised. ${ }^{350}$ Whilst most other developed countries were far advanced with replacing steam with diesel and electric traction, the newly nationalised British industry actually commissioned a new generation of steam locomotives to make the most of cheap and plentiful domestic coal. ${ }^{351}$ Notwithstanding the lack of litigation and the turmoil caused by wars and restructuring, it seems that fire damage caused by steam locomotives continued to be a major issue for the industry throughout this time.

In the interwar years the 'Big Four' railway companies continued to receive numerous complaints concerning fire damage. Letters from many disgruntled complainants, who had failed to make headway against the railway companies directly, can be found in the files of the Ministry of Transport. The limited scope of the regime, in terms of the type of property covered and the low cap on liability, is evident from many of these complaints. In one case an especially embittered farmer complained that a considerable amount of his fencing had been destroyed at great cost by a train operated by the London and North Eastern Railway (LNER). Although damage to fencing on agricultural land fell within the scope of the legislation, ${ }^{352}$ it seems that the low cap on liability meant that the compensation offered fell well short of the total damage costs:

They made me a small offer which would not replace half the fence they have destroyed, and seem to think I want to make money out of it. I do not [.] what I want is the fence making good so that I can graze the land which is useless to me in the state it now is. The Railway Co. seem to think they can give you what they like, as they know they are a powerful company and that small farmers are unable to fight them in the Law Courts. ${ }^{353}$

The letter gives the impression that a solution to the railway sparks issue was no closer than it had been at the dawn of the railway era a century earlier and that the attitude of the railway industry was no more enlightened. Aside from the destroyed fencing, the complainant had suffered crop damage on numerous occasions. Despite the fact that railways had become an indelible part of the landscape by this point, the Act under which the line was authorised was as profoundly resented as it had been when enacted in the previous century, 'The Government granted them the Act of Parliament to take our land, which no one in the Parish wanted to let them have it, and now they bring Fire through your property and burn up your crops, and want to give you just what they think fit'. ${ }^{354}$

The Ministry replied that it had no power to intervene in the matter and that any dispute could only be resolved by a court of law. ${ }^{355}$

A more unusual example, which also illustrated the limited scope of the Railway Fires Acts in terms of the type of property covered, concerned a burn mark to a dress caused by a red-hot cinder from a passing locomotive. ${ }^{356}$ Personal property such as clothing clearly fell outside the scope of the legislation. The railway company (once again the LNER) brushed aside the complaint and asserted that the spark arresting appliances on the locomotive were in good order and that the weight of the train was well within its capacity. In an internal memo an official in the Ministry of Transport admonished the company for standing on its legal rights "rather than do the obviously "gentlemanly" thing and compensate the lady for spoiling her dress' by way of an 'ex gratia' payment. ${ }^{357}$

\footnotetext{
350 The Transport Act 1947.

${ }^{351}$ The Railway Executive, 'Report of the Committee on Types of Motive Power' (unpublished internal report, 1951). See also Hugh Longworth, British Railways Steam Locomotives 1948 - 1968 (2nd edn, Oxford Publishing Co 2013).

${ }^{352}$ Railway Fires Act 1905 (5 Edw 7 c 11), s 4.

353 TNA MT6/3467, 13 May 1934 White to Stanley (Minister of Transport).

354 ibid.

355 TNA MT6/3467, 18 May 1934 Ministry of Transport to White.

356 TNA MT6/3467, 8 September 1933 Dun to Ministry of Transport.

357 TNA MT6/3467, 2 October 1933
} 
Nevertheless, the company remained implacable and it fell to an official in the Ministry to convey the bad news to the complainant. ${ }^{358}$

As the damaged dress example indicates, the railway companies were all too well of the fact that, where damage was not covered by the 1905 Act and recourse to the common law was necessary, complainants faced an uphill battle in terms of showing a wont of care on the part of the company. This is clearly shown by the LNER's response to a complaint brought by the managing agents of the Wroxham Estate in Norfolk in respect of fire damage caused by steam railcars. Having assured the Ministry that the spark arrestors were in good order, the company asserted that 'it was doing everything in its power to prevent fires arising from the emission of sparks from its engines'. ${ }^{359}$ However, it went on to point out that sparks could not be entirely eradicated and that the problem had been exacerbated by exceptionally hot and dry weather. In fact, the Clayton steam railcars (which would have been at issue in this case) were notorious for their propensity to emit sparks despite having been fitted with spark arrestors. Moreover, given their record of general unreliability, it is questionable whether they were as well engineered as they might have been. ${ }^{360}$

Few complainants, whose losses fell outwith the scope of the Railway Fires Acts, seem to have pursued litigation at common law; however, one notable example is provided by the highly unusual Scottish case of Cowie v LMS Rly Co. ${ }^{361}$ As noted above it was not unheard of for railway sparks cases to cause personal injuries and in one extreme example fatal injuries were sustained. However, Cowie appears to be the only example of litigation on the subject and the unusualness of the claim is heightened by the fact that it was for nervous shock. The pursuer had been walking along a street in Glasgow, which ran alongside the railway, when she was showered with red-hot cinders, some of which were 'aflame' and some of which were 'larger than a shilling'. She claimed $£ 500$ in damages arising from the 'severe nervous shock' caused by the incident. It was averred that such an 'unusual and extraordinary' shower of cinders must have resulted from negligence on the part of the railway company and its servants, whether due to the design, maintenance or operation of the engine. The defenders averred that their locomotives were, 'designed and constructed in accordance with the best modern practice, and are so designed and constructed as to secure the maximum efficiency in the combustion of coal and the minimum risk of the emission to atmosphere of sparks or unconsumed particles of coal' ${ }^{362}$

The reported element of the proceedings focused on whether the case was too complex to be tried by a jury and should thus be tried as a 'special cause' by a judge alone. ${ }^{363}$

In the Court of Session the Lord Justice-Clerk (Aitchison) affirmed that it was 'definitely settled that shock may be a good ground of action, even where the pursuer is unable to aver any outward physical or visible hurt'. ${ }^{364}$ He rejected the argument that the technical evidence regarding the mode of driving the engine or its design was overly complex and allowed the matter to proceed to trial by

\footnotetext{
358 TNA MT6/3467, 4 October 1933 Duffield (Ministry of Transport) to Dun.

359 TNA MT6/3467, 19 September 1933 Divisional General Manager LNER (Southern Area) to Ministry of Transport.

360 'The Clayton Steam Railcars', London and North Eastern Railway Encyclopaedia

<http://www.lner.info/locos/Railcar/clayton.php> accessed 15 July 2019.

361 [1934] SC 433, [1934] SLT 409.

362 [1934] SC 433, 435.

${ }^{363}$ Unlike England, civil juries for personal injury cases in Scotland have survived and are still used in some cases. In England trials by judge alone were first facilitated by the Common Law Procedure Act 1854 (17 \& 18 Vict c125). There was a gradual take up of the option to dispense with juries but matters were accelerated by the First World War, as there were simply not enough men available to sit on juries. Section 6 of the Administration of Justice Act 1933 afforded judges sole discretion as to whether a personal injuries claim should be tried by jury. However, trial by judge alone quickly became the default position. In Ward v James [1966] 1 QB 273 (CA) Lord Denning held that juries were never suitable for personal injury claims due to the complexities of assessing damages.

364 [1934] SC 433, 437.
} 
jury. Some months later a jury found unanimously in favour of the defendants having been persuaded by the technical arguments. ${ }^{365}$ Thus, as with many of the earlier Victorian cases, the litigant was unable to surmount the technical arguments adduced by the defendant.

Despite the limitations of the common law and the Railway Fires Acts there was little appetite for further legislative intervention. In February 1937 Mr Robert Gibson, the MP for Greenock, asked the Minister for Transport, Mr Hore-Belisha, to consider legislation requiring the electrification of all mainlines in dense urban areas and the use of electric locomotives thereon so as to reduce the fire risk to property. The question was submitted in advance and the minister's hand written note on the file gave the proposal short shrift: 'I am not aware of any appreciable risk of damage arising from this cause and am not prepared to introduce legislation of the nature indicated' ${ }^{366}$ An even terser response was given in the Commons: 'No evidence of appreciable risk is before me' ${ }^{367}$

\section{B. Into the Second World War}

Complaints regarding fire damage continued into the Second World War. In one case the London Midland and Scottish Railway (LMS) rejected a claim in respect of substantial fire damage caused to moorland on the Breadalbane Estate in the Scottish Highlands; as noted above, moorland was expressly excluded from the scope of the 1905 Act. This focused attention on whether the company had taken reasonable steps to mitigate the risk of sparks by fitting appropriate appliances to the locomotive. There is no mention of spark arrestors in the correspondence between the Railway Executive Committee and the Ministry of War Transport, and it seems that the railway company's assertions that brick arches and baffle plates would suffice were accepted unquestioningly. ${ }^{368}$ As we have seen above, the adequacy of brick arches was debated in the case of Davies $v$ London and North Western Railway ${ }^{369}$ some 70 years earlier. Thus, so far as the officials in the relevant government departments were concerned, there had been no improvement in the state of the art since Victorian times. One possible explanation for this attitude is that the incident occurred against the backdrop of the Second World War and wartime austerity may have been a contributing factor. Given the immense strain on the railways, damage to moorland may not have been regarded as being of the utmost concern. However, a manufacturer of industrial lubricants reclaimed from waste products met a similar response in respect of a claim arising from substantial fire damage to his premises caused by a spark from a LMS locomotive during the war. The bitterness and frustration experienced by the small family business is palpable in the following extract from the correspondence:

We cannot understand why we cannot have help from some direction, to put back that which has been burnt by railway sparks. The LM \& S Railway Co simply leave us without a roof over our heads, and they can get away with it free, that, which as [sic] been built by our sweat and blood, and our Parents before us. ${ }^{370}$

The complainant continued that the lubricants produced were essential to the local coal mining industry but these arguments cut no ice. Once again the Ministry informed the claimant that he would need to pursue the matter before the courts where, given the exclusion of such property damage from

\footnotetext{
365 'Cinders from Engine: Glasgow Woman's Damages Claim Fails', The Scotsman (Edinburgh, 3 November 1934) 6.

366 TNA MT6/3467, file note dated 14 February 1937.

${ }^{367}$ HC Deb 17 February 1937, vol 320, col 1182

368 TNA MT6/3467, 17 August 1942 G Cole-Deacon (Railway Executive Committee) to GGD Hill (Ministry of War Transport).

369 (n 162). These assurances were received from Sir William Wood, no less, the President of the LMS.

370 TNA 115/89, 5 September 1947 Andrew Gough to Ministry of Transport. Gough had initially written to his MP, Col Wigg, having failed to make headway against the railway company. Col Wigg then forwarded the letter to the Ministry.
} 
the scope of the Railway Fires Act, it would be necessary to establish negligence on the part of the railway company. ${ }^{371}$

Despite the formidable difficulties associated with establishing fault on the part of the railway companies, a limited number of attempts were made to establish liability at common law in respect of harm which fell outwith the limited scope of the Railway Fires Acts. The law reports contain two contrasting wartime decisions of the Kings Bench Division (KBD) regarding the necessity of fitting spark arresting devices.

In Parker $v$ London and North Eastern Railway ${ }^{372}$ damages were sought in respect of crop damage amounting to $£ 4630$, which far exceeded the cap on liability under the legislation. The fire was caused by a spark emitted from a locomotive hauling a three coach local passenger train on a branch line in Norfolk. The locomotive in question had not been fitted with any form of spark arresting device. ${ }^{373}$ Denning J held that it was well settled that, in the railway sparks cases, the onus remained on the plaintiff to establish negligence. ${ }^{374}$ Moreover, he acknowledged that there had been a retreat from the approach based upon res ipsa loquitur adopted in the early cases. ${ }^{375}$ Nevertheless, the plaintiff managed to secure a rare victory on the technical evidence.

Denning J appeared to relish the engineering arguments ${ }^{376}$ and concentrated on the aforementioned vortex blast cases of the 1890s. It will be recalled that the railway companies successfully argued that spark arrestors were not necessary and unduly affected the efficiency of locomotives. However, Denning J (as he then was) asserted that technology had moved on considerably since that time. In this respect the judge was particularly impressed by the expert evidence of the renowned locomotive designer Sir William Stanier, Chief Mechanical Engineer (CME) of the LMS and former CME of the GWR, ${ }^{377}$ regarding the merits of the 'self-cleaning smokebox'. Stanier had originally developed the device during his tenure as CME of the GWR where it had been used with some success on a number of locomotives. He later brought the technology to the LMS where it was further refined and employed on new locomotives. Furthermore, Stanier could see no reason why the device could not have been retrofitted to existing locomotives such as the one which caused the fire in this case. ${ }^{378}$ The CME of the defendant company, Edward Thompson, had to concede that the LNER had in fact fitted the equipment to certain other types of locomotive. ${ }^{379}$

In short the device was a development of a US invention, the pressure equalisation plate, which equalised the pressure of exhaust gases passing through the fire tubes and into the smoke box so as to produce a more even draft. ${ }^{380}$ The device had the added bonus of reducing the quantity of large cinders drawn down the fire tubes and ejected into the open air. Moreover, it could be used in conjunction with a steel mesh spark catcher without impairing the steaming capacity to an unacceptable extent. The icing on the cake was the fact that the gases flowed in such a way that the

\footnotetext{
371 TNA 115/89, 12 September 1947, EW Godfrey (Ministry of Transport) to Andrew Gough. 372 (1945) 175 LT 137.

${ }^{373}$ The locomotive is identified in the case report as bearing the number 8878; from this it is possible to determine that it was an elderly Ivatt J52 tank engine originally built for the Great Northern Railway in 1905. See RailUK database <http://www.railuk.info/steam/getsteam.php?row_id=20518> accessed 28 September 2017.

${ }^{374}$ Parker (n 372) 138 citing Herschell LC in Port Glasgow and Newark Sailcloth (n 134). The reasons for this state of affairs are explained above under 'Negligence and Statutory Authority'.

375 Parker (n 372) 137-38.

${ }^{376}$ It is perhaps worth remembering that Denning was of a scientific bent and gained a first in mathematics at Oxford. In the Great War he served with the Royal Engineers. See Lord Denning, The Family Story (Butterworths 1981).

${ }^{377}$ For biographical details, see OS Nock, Sir William Stanier: an Engineering Biography (Ian Allen 1964).

378 Parker (n 372) 139.

379 ibid.

${ }^{380}$ In his evidence Stanier attributed the development of the basic technique to the US locomotive engineer and inventor Professor William Goss. See Parker (n 372) 138.
} 
accumulation of ash in the bottom of the smokebox was greatly reduced - thus explaining the use of the term 'self-cleaning smokebox'.

As regards the standard of care which could be expected of the defendants, Denning J repeated a test which will be familiar from the doctrinal analysis above: The defendants 'were bound to avail themselves of all the discoveries which science has put within their reach for that purpose, they were bound to adopt them, provided that they were such that, in the circumstances, it was reasonable to require them to adopt ${ }^{3}$. ${ }^{381}$

In the light of the technical evidence, he had no doubt that the company had failed in this duty in that a proven technology had emerged which ought to have been rolled out much sooner. In marked contrast to the views expressed in the files of the Ministry of Transport at the time, ${ }^{382}$ it seems that Denning J was of the opinion that the brick arch and deflector plate would no longer suffice.

However, the following year another High Court judge came to the opposite conclusion on similar technical evidence, although he still found in favour of the plaintiff on other grounds.

In Sellwood v LMS Rly Co ${ }^{383}$ the plaintiff's flat in Leytonstone had been set alight by sparks from a passing goods train in August 1944. It seems that a red-hot cinder may have flown through an open window. In the King's Bench Division, Hallet J rejected an argument that the railway company had been negligent in failing to fit any form of spark arresting device to the locomotive in question. It will be recalled that the CME of the LMS, Sir William Stanier, had played a pivotal role in persuading Denning $\mathrm{J}$ of the merits and availability of spark arrestors in the Park case. Thus, it is somewhat ironic that on this occasion the LMS found itself delivering the familiar counter argument that it was not reasonable for railway operators to fit such devices as a matter of course due to their deleterious effect on the performance of engines. It was acknowledged that, under the auspices of Stanier (who did not appear to have given evidence in this case), the self-cleaning smokebox had been fitted to 1200 of the larger classes of LMS locomotives. ${ }^{384}$ Nevertheless, the company was far more ambivalent about the success of the device than Stanier had been in his evidence in the Parker case. Hallett $\mathbf{J}$ stated that the equipment had been removed from some locomotives, resulting in immediate improvements in performance. ${ }^{385}$ Moreover, it was suggested that the device was not suitable for all locomotives in any case, and a conscious decision had been made not to fit it to the locomotive in question. ${ }^{386}$ Finally, it was submitted that the equipment required too much maintenance and labour under wartime conditions. ${ }^{387}$ In fact, the wartime austerity argument proved decisive on the issue, and Hallett $\mathrm{J}$ held that it had a major bearing on what constituted reasonable measures to abate the risk:

In considering what is reasonable, regard must be had to all the circumstances. The London Midland and Scottish Railway Company were at the time performing services of the highest public importance. They were working under all the various difficulties of war time, and delay through loss of steaming efficiency would be most serious from the public point of view. ${ }^{388}$

Hallett $\mathrm{J}$ briefly acknowledged that, as regards the necessity of fitting spark arresting systems such as the self-cleaning smokeboxes, his conclusions appeared to differ somewhat from those of Denning J in Parker. ${ }^{389}$ However, he was adamant that their respective judgments were on all fours in terms of their interpretation of the law, and it was only the individual facts which had led them to reach differing conclusions. However, the judge did not expand upon what these factual differences

\footnotetext{
${ }^{381}$ Parker (n 372) 139-38 (Denning J) citing Williams J in Freemantle v London and North Western Rly Co (n 148).

382 See, for example, correspondence relating to the moorland fire on the Breadalbane estate (n 368).

383 (1946) 175 LT 366.

384 ibid 368.

385 ibid.

386 ibid.

387 ibid 367.

388 ibid 368

389 ibid.
} 
were. It is notable that the wartime austerity argument featured heavily in Sellwood, whereas it had not featured at all in Parker. This is possibly explicable on the basis that in Parker the fire had been caused by a three-coach local passenger train, whereas in Sellwood the sparks had been emitted from a heavy goods train on vital war work. This would have been a most unsatisfactory distinction in that one's entitlement to damages would have rested on what type of work the offending locomotive had been engaged in, thus making one's entitlement to damages somewhat of a lottery.

All was not lost for the plaintiff, however, in that Hallett $\mathrm{J}$ went on to consider whether there had been any negligence in terms of how the locomotive had been operated. In giving evidence the driver and fireman, perhaps not surprisingly, confessed that they had no recollection of that specific journey. ${ }^{390}$ Nevertheless, they admitted that, because of the manner in which it was necessary to fire and drive the locomotive on the section of track in question, there would not normally have been an excessive emission of sparks. ${ }^{391}$ On the basis of this admission, the judge was prepared to find that there had been negligence in the mode of operating the engine. ${ }^{392}$ This is a remarkable conclusion to have reached on very thin evidence, especially given that the footplate crew had no recollection of the night in question and there was no reference to eyewitness testimony. Moreover, Hallet J suggested that there may have been a minor lapse 'of which even the most careful fireman may sometimes be guilty... ${ }^{393}$ This was a huge assumption to make; and even assuming it were true, such a lapse scarcely seems redolent of culpability sufficient to constitute a breach of the duty of care.

One possible explanation is that the judgment is an example of loss allocation between parties which were both likely to have been insured. The judge may have felt it appropriate to channel liability to the railway company but may not have wanted to establish any precedent to the effect that spark arrestors should have been fitted as a matter of routine under wartime conditions. This could well have opened the floodgates to a raft of similar fire damage claims.

Thus, by the end of the Second World War and the demise of the 'Big Four' (which in fact had been operated as a nationalised industry during the war in any case), a solution to the sparks problem seemed no closer at hand.

\section{Post-war nationalisation}

The railway sparks problem continued unabated following nationalisation of the railway industry in the immediate post-war years. ${ }^{394}$ Following a series of large fires, exacerbated by the hot summer, in Kent in 1949, a local MP, EP Smith, instigated a debate on whether farmers should be advised to plant less flammable crops in the vicinity of railways. ${ }^{395}$ Having taken advice from the Ministry of Agriculture, the Minister for Transport, James Callaghan, informed Smith that the suggestion was impracticable because of crop rotation and the need to maintain cereal production at a time of national shortage. Callaghan assured the MP that the number of fires that year had been exceptional because of the unusually hot and dry conditions and that all reasonable measures were being taken to mitigate the risk. Nevertheless, the Minister concluded that where the risk was especially acute 'the farmer, who is a pretty shrewd fellow, will in his own interest take some such step' ${ }^{396}$ There is evidence to suggest that farmers did indeed take this step in some cases. For example, oral history accounts suggest that one farmer near Trumpington planted alfalfa near a railway embankment in order to mitigate the fire

\footnotetext{
390 ibid.

391 ibid 368-69.

392 ibid 369.

393 ibid.

${ }^{394}$ See Transport Act 1947.

395 TNA 115/89, 12 September 1949, Edward P Smith MP to James Callaghan (Minister for Transport). The enquiry was prompted by a letter from a constituent, one Matt Fright, regarding the fires.

396 TNA 115/89, 31 October 1949 Callaghan to Smith.
} 
risk - an approach highly redolent of the economic analysis of tort which was outlined towards the beginning of this article. ${ }^{397}$

There was still no clear policy on the fitting of spark arrestors and, in relation to the aforementioned fires in Kent, British Railways was reported as repeating the familiar mantra that such devices would unduly impair the performance of locomotives. ${ }^{398}$ This position is corroborated by a Railway Executive Report of 1951 in which it was concluded that it would be necessary to rely upon steam as the primary means of motive power for many years to come. ${ }^{399}$ Wholesale replacement of steam traction by diesel and electric motive power was deemed too costly at a time of austerity. The report acknowledged the extent of the railway sparks problem and referred to the exceptionally hot summer of 1949, which was the cause of the excessive fire damage in Kent. ${ }^{400}$ The report noted that all new locomotives were fitted with spark arrestors as a matter of course. However, it asserted that older locomotives could not be retrofitted with spark arrestors without 'materially affecting their steaming capacity'. ${ }^{401}$ In order to reduce the 'spark throwing' propensities of these older engines, increased skill in firing, better quality coal, improved maintenance regimes and more clearance of lineside vegetation would provide the only solutions. ${ }^{402}$

The lack of progress on the spark arrestor issue prompted one retired driver to write to the Ministry recalling the fact that he had tested a device on a locomotive (a Stirling 4-4-0-F) some thirty years previously. It seems that a somewhat vague and informal response was given which referred to the fact that many more recent locomotives, such as the V2, had spark arrestors. ${ }^{403}$ Moreover, in the aforementioned correspondence between EP Smith MP and the Ministry of Transport relating to the Kent fires and the alternative crop planting suggestion, the Ministry asserted that the new generation of BR standard steam locomotives currently in development would all be fitted with the latest spark arresting devices. ${ }^{404}$ In correspondence relating to other fires, there was no mention of spark arrestors at all. In response to a complaint, relating to considerable fire damage caused to fields of corn and hay growing alongside the Havant to Hayling Island branch line, ${ }^{405}$ British Railways asserted that 'the careful working of engines' and the maintenance of a $3 \mathrm{ft}$-fire border on either side of the railway would suffice to minimise the fire risk. ${ }^{406}$

It was also clear that nationalisation introduced a new set of problems in that there was no arm's length regulator; this resulted in possible conflicts of interest between different public bodies. In one case railway sparks emitted by colliery locomotives caused crop damage to a research station owned by the Ministry of Agriculture. The claim exceeded the $£ 200$ cap on liability under the Railway Fires

397 Trumpington Local History Group, 'Introduction to Railways in Trumpington' <www.trumpingtonlocalhistory.org> accessed 7 June 2016. Recall that an economist might argue that a more efficient solution is for the farmer to use the land adjacent to the railway for purposes which are less susceptible to fire damage. See section entitled 'Railway Sparks, Economics and Legal History', above at n 4.

${ }^{398}$ TNA 115/89, transcript of article in Kent Messenger entitled 'Just Like a Blitz for Kent' sent by Matt Fright to EP Smith and forwarded to Ministry of Transport (n 395).

399 The Railway Executive, 'Report of the Committee on Types of Motive Power' (n 351).

400 ibid [223].

401 ibid [224].

402 ibid.

${ }^{403}$ The actual letters and copies thereof are missing from the file but internal memos between the Ministry of Transport and the Railway Inspectorate outline the nature of the response which should be drafted: TNA 115/89, 1 February 1951 GRS Wilson (Railway Inspectorate) to Gingell (Ministry of Transport).

404 TNA 115/89, 24 October 1949, Henderson to Smith. The undertaking to equip all new BR standard locomotives with spark arrestors is corroborated by the Railway Executive Committee Report on motive power (n 399).

405 TNA 115/89, 3 July 1957, AG Walter to Minister of Transport.

406 TNA 115/89, 20 August 1957, D McKenna (Asst General Manager BR Southern Region) to AG Walter. These precautions mirror the recommendations of the 1951 Railway Executive Motive Power report. It should also be noted that, right up until the day of its closure in 1962, the Hayling Island Branch was operated by elderly class A1X 'Terrier' tank engines originally built for the London, Brighton and South Coast Railway to haul London suburban commuter trains. 
Act, and the Ministry wanted to know whether, for the purposes of determining liability at common law, there was evidence of negligence in terms of the design or operation of the locomotives. To this end it attempted to enlist the help of the Railway Inspectorate. ${ }^{407}$ Internal memos demonstrate a degree of unease at the possibility of one public body (the Railway Inspectorate) helping another public body (the Ministry of Agriculture) to bring a claim against a third public body (the British Transport Commission as operator of British Railways). ${ }^{408}$ Aside from the conflict of interest issue, it seems that the Railway Inspectorate did not regard such fires as falling within its competence in any case in that they did not directly impinge upon the running of trains and the safety of the travelling public. ${ }^{409}$ As noted above, this attitude can be traced back to the outset of railway regulation in the 1840s when attempts to bring lineside fires within the scope of early legislation were rebuffed. Thus, the request for help in this case was firmly rejected claiming that 'this would be quite outside the function of the Inspectorate and there would be most undesirable repercussions if the Inspecting Officers of Railways were to do anything of the kind'. ${ }^{410}$

The fact that the Railway Inspectorate eschewed responsibility for railway sparks underscores the fact that there was no effective public regulation of the issue and complainants had no alternative other than to fall back on the limited compensation regime or their remedies at common law.

As regards the role of the common law at this time, the Railway Executive acknowledged that a significant proportion of the damage caused by locomotive sparks was not covered by the Railway Fires Acts. However, the need to show fault on the part of the railway operator, for the purposes of establishing liability at common law, continued to present potential litigants with evidential difficulties. In Henry Balfour \& Co Ltd $v$ The Railway Executive, ${ }^{411}$ the somewhat unlikely claimants, given the fiery nature of their own occupation, were the proprietors of a foundry. The pursuers claimed some $£ 40,000$ in damages in respect of a fire in a warehouse caused by a glowing cinder emitted by a passing engine, a form of loss which clearly fell outwith the scope of the Railway Fires Acts. It was alleged that the locomotive, an old engine which had been built by the pre-grouping North British Railway before 1914, had not been fitted with any spark arresting devices. In the Outer House of the Court of Session, Lord Strachan, citing Herschell LC in Port Glasgow and Newark Sailcloth ${ }^{412}$ stated that the railway companies 'are bound to use the best practicable means, according to the then state of knowledge, to avoid the emission of sparks' ${ }^{413}$ His Lordship held that the issue of whether this test had been met by the defendants in the case at hand was a proper question to be put before a jury ${ }^{414}$ However, there appear to be no further law reports or press reports on the litigation, which suggests that the case was dropped or the parties settled out of court. ${ }^{415}$

Nevertheless, the fact that juries were still often used in the Scottish courts meant that the outcome could never be certain and the occasional victory was still secured. In the unreported case of M'Laren v Railway Executive ${ }^{416}$ damages of $£ 508$ were sought in respect of the loss of four stacks of oats. The value of the claim and the fact that the crops were stacked resulted in the matter falling outside the scope of the Railway Fires Acts, thus necessitating an action at common law. Technical

\footnotetext{
407 TNA 115/89, 23 February 1954 H Garside (Ministry of Agriculture Fisheries and Food) to MP Beazley (Ministry of Transport and Civil Aviation).

408 TNA 115/89, 2 March 1954 MP Beazley (Ministry of Transport and Civil Aviation) to Col Wilson (Railway Inspectorate).

409 TNA 115/89, 3 March 1954 Col Wilson to MP Beazley.

410 TNA MT115/89, 6 March 1954 MP Beazley to H Garside.

411 (1950) SLT (notes) 43.

412 Port Glasgow and Newark Sailcloth Co v Caledonian Rly Co (n 134).

413 (n 411).

414 ibid.

415 The early stages of the litigation and the proceedings in the Outer House received a reasonable amount of press attention, thus it is unlikely that any trial would not have been covered. As regards press coverage of the reported proceedings, see 'Firm Says Engine Spark Began Fire: £40,000 claim’ Dundee Evening Telegraph (10 May 1950) 6.

${ }^{416}$ The Scotsman (Edinburgh, 2 Dec 1950) 3.
} 
arguments, adduced by the Railway Executive, to the effect that sparks arrestors could not have been fitted to the types of locomotive which operated on the line in question ${ }^{417}$ failed to impress the jury and the damages were awarded.

\section{The demise of steam}

In the 1950s a technical solution to the holy grail of arresting sparks without impairing the performance of locomotives to any great extent appeared to be at hand. A German innovation, the Giesl ejector produced a draft so powerful it more than overcame any interference caused by spark arrestors. The inventor first approached British Railways in 1951 but was rebuffed. While some limited trials of the device were conducted in the UK in the early 1960s, the device was not adopted as standard. ${ }^{418}$ Given that diesel and electric traction were beginning to take over, albeit at a much slower rate in the UK than in continental Europe, it may not have been considered worth investing in such technology. As noted above, aside from fitting spark arrestors to the new BR standard locomotives, there was no programme of retrofitting devices to older locomotives across the fleet. Fire damage claims continued until the last days of steam and correspondence relating to the destruction of a timber yard appears in the files of the Ministry of Transport as late as March 1965. The correspondent, an insurance loss adjustor, was directed to pursue the claim directly with British Railways. The letter was headed 'Railway Fires Act 1905 and 1923'; however, as should now be abundantly clear, this type of loss would have fallen outwith the scope of the Acts.

In any event, the replacement of steam by diesel and electric traction occurred more rapidly than the Railway Executive had originally anticipated, ${ }^{419}$ and the last scheduled steam services operated by British Railways ran in 1968. Thereafter the issue largely slipped into history, although from time to time fires caused by preserved steam locomotives on charter trains or on heritage railways offer live demonstrations of this once commonplace nuisance. ${ }^{420}$

\section{CONCLUSIONS}

The railways transformed the British Isles, and indeed the world, in many ways. ${ }^{421}$ Aside from their irreversible impact on the landscape they altered the whole nature of the economy and brought about dramatic social changes. Towns and cities were brought closer together by the first national rapid communications network.

\footnotetext{
417 The Kelso branch line.

${ }^{418}$ It was trialled on a very limited number of Bullied Pacific locomotives in 1962 with great success but was less effective on a heavy 9F freight locomotive (one of the new BR standards designs), although some other modifications to the locomotive could have improved results. As regards the Bullied Pacifics, see 'The Giesl Ejector and 34064 'Fighter Command' <http://svsfilm.com/nineelms/giesl.htm> accessed 31 August 2017 reproducing the text of detailed firing notes circulated to firemen and witness testimony from footplate crews. As regards 9F trials, see D Wardale, The Red Devil and other Tales from the Age of Steam (Plough Book Sales 1998) 132. The author was a locomotive engineer who worked on the project. ${ }^{419}$ See (n 399).

${ }^{420}$ Most recently the heatwave of the summer of 2018 created challenging conditions for the operators of heritage lines. See, for example, "Large increase" in line-side fires among challenges faced by railway', Telegraph and Argus (Bradford, 19 August 2018)

$<$ https://www.thetelegraphandargus.co.uk/news/16444926.large-increase-in-line-side-fires-among-challengesfaced-by-railway/> accessed 3 October 2018 regarding the Keighly and Worth Valley Railway. A number of lines, including the Snowdon Mountain Railway and the Severn Valley Railway, suspended steam-operated service altogether. See Kelly Williams, 'Snowdon railway suspends steam trains after they spark fires during heatwave' (WalesOnline, 5 July 2018) <https://www.walesonline.co.uk/news/wales-news/snowdon-railwaysuspends-steam-trains-14867864> accessed 23 September 2019; 'Severn Valley Railway temporarily replaces steam with diesel to reduce lineside fire risk' (Shropshire live, 11 July 2018)

<https://www.shropshirelive.com/news/2018/07/11/severn-valley-railway-temporarily-replaces-steam-withdiesel-to-reduce-lineside-fire-risk/> accessed 3 October 2018.

${ }^{421}$ As GM Trevelyan put it, the railways were 'Britain's gift to the world', see English Social History (2nd edn, Longmans, Green \& Co 1946) 531.
} 
At the outset of the railway revolution, few would have anticipated the profound impact which the railways would have on the British way of life. A notable exception was the engineer Thomas Gray, who proposed a national network of steam operated railways before the Stockton and Darlington Railway had even been built. ${ }^{422}$ However, as with many other aspects of industrialisation, the technology brought with it costs in addition to benefits. Fire damage caused by railway sparks was a classic example of what economists call an externality. This is why the railway sparks issue caught the attention of the proponents of the economic analysis of tort.

It is unlikely that Thomas Gray would have anticipated the extent of the railway sparks problem, and it was clearly not foreseen by Parliament which resisted early attempts to include specific provisions on the problem in early legislation. The limited compensation regime which was eventually introduced under the Railway Fires Acts of 1905 and 1923 was entirely inadequate, and the fire damage problem was never resolved throughout the entire history of steam traction on British railways.

The failure of the law to keep pace with technological change is a familiar story, especially in the context of industrialisation. Much has been written about attempts to use the law of public and private nuisance to fill the vacuum left by the lack of a regulatory response to pollution. ${ }^{423}$ The response of the common law to the railway sparks problem follows this pattern in many respects. There can be no doubt that, ultimately, the common law failed spectacularly to compensate for the lack of statutory intervention.

The economic analysis outlined at the beginning of this article only skates around the historical issues and does not provide a full or accurate picture of what actually happened in the case law. Coase made much of the fact that the railway companies benefitted from a statutory authority defence, and Simpson was right to point out that it was the courts that developed this defence rather than the legislature. However, the fact that the defence prevented strict liability from operating in the vast majority of cases does not in itself explain why the railway companies largely escaped liability. Although the cases were brought in negligence, the courts initially set the bar very high in terms of the standard of care expected of the defendant. In fact, the standard was tantamount to res ipsa loquitur and the only way to rebut the assumption of fault was to show that spark arresting devices had been fitted. This approach amounted to a form of judicial legislation in that, although the Board of Trade may have declined to impose technical requirements on the railway companies, the courts took it upon themselves to ensure that spark arrestors were fitted. Here we can see the echoes of the argument that the rule of strict liability arising from Rylands $v$ Fletcher was a form of judicial legislation prompted by a failure of the legislature to deal with the problem of reservoir collapses. ${ }^{424}$ Indeed, the railway sparks cases are an important precursor to Rylands v Fletcher, and it is significant that Blackburn $\mathbf{J}$ was involved in such cases both before and after his seminal judgment. It is a short step from a high standard of care to strict liability, which means that the courts could have held the railway companies accountable for a higher proportion of the damage costs whilst maintaining the language of negligence. ${ }^{425}$

\footnotetext{
${ }^{422}$ Gray published his ideas in Observations on a General Iron Railway (Baldwin, Craddock and Joy 1820).

${ }^{423}$ Of the voluminous literature, a seminal piece remains JPS McLaren, 'Nuisance Law and the Industrial Revolution-Some Lessons from Social History’ (1983) 3 OJLS 155.

${ }^{424}$ Simpson explains that the Rylands litigation coincided with a failed attempt to pass legislation which would have established strict liability in respect of damage caused by reservoirs and set up an inspectorate under the auspices of the Board of Trade. There are strong similarities here with the failed attempt to establish strict liability for railway fire damage under the Railway Regulation Act 1842 (5 \& 6 Vict c 55) in conjunction with a regulatory function for the Board of Trade. See Simpson (n 14) 205-06. Thus in both cases the Board of Trade missed an opportunity to get to grips with a serious externality caused by industrialisation.

${ }^{425}$ It is for this reason that the High Court of Australia saw no reason to maintain Rylands v Fletcher as a distinct cause of action in Burnie Port Authority v General Jones Pty Ltd (1994) HCA 13, (1994) 179 CLR 520
} 
However, as we have seen, the high standard of care established by the earlier cases was continually watered down as the century progressed. The railway companies used all their resources and expertise to fight any legal requirement to fit spark arrestors as they struggled to develop a device which did not adversely affect the performance and operating costs of locomotives. Ultimately, these technical arguments undermined judicial confidence that spark arrestors constituted the best practicable means of dealing with the problem. Contrary to what Simpson asserted, when Parliament finally got around to considering the need for legislation, following extensive lobbying by the agricultural sector, a clear and deliberate decision was taken, to use Simpson's words, 'to be kind to the Railway companies' ${ }^{426}$ This was a direct consequence of the fact that railway interests were heavily represented in a Commons which, at that time, had little concept of conflict of interest. ${ }^{427}$

In conclusion, the railway sparks issue tells a familiar story of how the common law reacts, or fails to react, to technological change. Moreover, it demonstrates how the innovator of a technology may in fact shape the manner in which the law responds for its own ends. Initially the railways were regarded as an alien and invasive technology, and the onus was on the railway companies to justify the use of steam locomotives and to pay for any damage: 'This infernal nuisance- the loco-motive monster carrying eighty tons of goods, and navigated by a tail of smoke and sulphur, coming thro' every mans' grounds between Manchester and Liverpool', as the great railway opponent Thomas Creevey MP put it when commenting on the Liverpool and Manchester Railway Bill. ${ }^{428}$

We can see such attitudes reflected in the judgment of Bramwell B in the Court of Exchequer proceedings in Vaughan $v$ Taff Vale Rly Co who espoused the view that, if a steam locomotive cannot be operated safely, irrespective of how many precautions have been taken, then its mere use is culpable. ${ }^{429}$ However, the railways grew with astonishing rapidity and became established and indelible parts of the landscape within a very short space of time. ${ }^{430}$ Once they had been normalised in this way, the onus then seemed to shift onto the victims of railway sparks to show what was abnormal or culpable about the manner in which a railway company had conducted its operations. The result of this is that the railway companies were never made to internalise a large proportion of the costs of fire damage, or, as Bramwell B put it, to 'pay their expenses'. ${ }^{431}$ Given the impact of the railways on modern civilisation as a whole, one can only wonder whether, with a longer view of history, Bramwell B would have adhered to his view that, in the absence of compensation, the fire damage costs outweighed the public benefits. His closing comments in Powell v Fall, ${ }^{432}$ in which he steadfastly refused to countenance any notion of extending statutory authority to road-going locomotives, suggest that he would never have accepted that the fire damage was a price worth paying. Moreover, if he shared his younger engineer brother Frederick's faith in engineering solutions, he may never have accepted that it was a price that had to be paid.

\footnotetext{
${ }^{426}$ Simpson (n 16) 100.

${ }^{427}$ See Tim Lankester, Conflict of Interest: A Historical and Comparative Perspective (unpublished research paper, University of Oxford July 2007).

${ }^{428}$ Sir Herbert Maxwell (ed), The Creevey Papers: a selection from the correspondence and diaries of the late Thomas Creevey, MP (John Murray 1904) 87-88.

${ }^{429}$ Vaughan (Exchequer) (n 95).

${ }^{430}$ On hearing of the imminent arrival of the railways in his beloved Lake District, Wordsworth inevitably expressed his fears in poetic terms: 'Is there no nook of English ground secure From rash assault?', published in the Morning Post (London, 12 October 1844). However, as Biddle explains, 'once the navvies, masons and bricklayers had gone and the new railways' scars had healed, cuttings and embankments grown over and trees and bushes established, even the deepest and highest earthworks were steadily absorbed into the landscape, a process aided by turfing seeding to assist them to stabilise': see Gordon Biddle, Railways in the Landscape (Pen and Sword Transport 2016) 18.

${ }^{431}$ See Bamford v Turnley (n 106).

${ }^{432}$ Powell (n 120).
} 
